\title{
MONETARY POLICY RULES AND BUSINESS CYCLES
}

Soyoung Kim 


\section{MONETARY POLICY RULES AND BUSINESS CYCLES}

Soyoung $\operatorname{Kim}^{(*)}$

(1) This paper was made whilst I was a visiting research fellow ant the Banco de España. Correspondence address: Department of Economics, 225b DKH, 1407 W. Gregory Dr., Urbana, IL 61891, e-mail:kim11@uiuc.edu. I thank William Gavin, Earl Grinols, Jinill Kim, Tom Kret s, Christopher Sims, Case Sprenkle, and Javier Vallés, for comments and discussions. 1 also thar lk Kitikhun Borvomboonrutai for research assistance. All remaining errors are mine.

Banco de España - Servicio de Estudios

Documento de Trabajo no 9804 
In publishing this series the Banco de España seeks to disseminate studies of interest that will help acquaint readers better with the Spanish economy.

The analyses, opinions and findings of these papers represent the views of their authors; they are not necessarily those of the Banco de España.

The Banco de España is disseminating some of its principal reports via INTERNET and INFOVIA.

The respective WWW server addresses are: http://www.bde.es and http://www.bde.inf.

ISSN: 0213-2710

ISBN: 84-7793-593-9

Depósito legal: M. 7547-1998

Imprenta del Banco de España 


\begin{abstract}
Business cycle properties under different monetary policy rules are examined in a variety of dynamic stochastic general equilibrium models (the real business cycle models, the nominal wage contract models with different length of contracts, and the monopolistic competition models with different size of price adjustment costs). The experiments show that nominal and real features of business cycles are substantially different under different monetary policy rules. In particular, the business cycle properties under the AR-1 rule is substantially different from the business cycle properties under the realistic monetary policy rule estimated from data, allowing endogenous reactions to the state of economy. Regarding the real features of business cycles, the changes under different monetary policy rules are as large as the changes generated from introducing rigidities themselves and monetary disturbances. Other experiments show that the presence of the nominal liquidity effect may critically depend on the specification of monetary policy rules and that movements of real variables can be substantially different under different monetary policy rules even in the case of small nominal rigidities (or small real effects of monetary policy shocks). These results suggest that incorporating the realistic monctary policy rule is important for monetary business cycle research and that the monetary authority has the potential to affect real economy substantially by adopting different monetary policy rules.
\end{abstract}





\section{Introduction}

This paper examines the role of monetary policy rules in business cycles, or the effecis of different monetary policy rules on business cycle properties. This research is motivated by the trend that very few works systematically investigate the effects of different monetary policy rules on business cycle properties within the dynamic stochastic general equilibrium (DSGE) modes even though there have been a wealth of research introducing monetary (policy) disturbances to DSGE models with simple monetary policy rules or investigating the effects of monetary (policy) disturbances

Most past studies introducing money to DSGE models to explain business cycles have specified simple monetary policy rules. Most common specification is the AR-1 money growth rate rule (or AR-1 log of money growth rate rule) with monetary disturbances, for example, Cooley and Hansen [1989,1995], Cho and Cooley [1995] and Christiano and Eichenbaum [1992].

Exceptions within the DSGE models are Leeper and Sims [1994], Rotemberg and Woodford [1997] and Gavin and Kydland [1995]. Leeper and Sims [1994] introduced and estimated more complicate but more realistic monetary policy rules. Gavin and Kydland [1996] suggested that different monetary policy rules generate different nominal features of business cycles (variances of nominal variables and covariances between nominal variables and real variables).'

Outside DSGE business cycle models, there has been more realistic consideration of monetary policy rules. One is VAR literature that tries to identify monetary policy shocks. ${ }^{2}$ These studies specified and estimated more realistic monetary policy rules but most of thein studied the effects of monetary policy disturbances on business cycles. Some research in VAR literature, for example, Sims and Zha [1995] and Kim [1995], and some studies using aggregale models, for example, Talyor [1993], studies in Bryant, Hooper, and Mann [1993], and Fuhrer ard Moore [1995] examined the effects of different monetary policy rules and regimes. But those models are not constructed with full microfoundations and they examined some limited featur:s of business cycles.

\footnotetext{
'There are other studies assuming a more sophisticated rule than the simple AR-1 rule. J.Kim [1996], King and Watson [1996], and Yun [1996] incorporated some aspects of endogeneity of money. But it seems difficult to interpret them as an approximation to the monetary authority's stabilization behavior.

${ }^{2}$ See Leeper, Sims, and Zha [1996] for the summary of the literature.
} 
Another related research is the theoretical literature comparing different monetary policy nules, especially the fixed money rule and the fixed interest rate rule. ${ }^{3}$ But these studies assumed relatively simple structure of models or did not systematically examine business cycle properties by concentrating on welfare comparison.

In this paper, I systematically examine the effects of different monetary policy rules on business cycles by constructing a variety of the DSGE models. A general question explored is how large is the effects of monetary policy rules on business cycles. A specific question explored is how good simple exogenous specification of monetary policy rules assumed by previous sudies, such as the AR-1 money growth rate rule with monetary disturbances, are as approximations or how important it is to incorporate a realistic monetary policy rule.

First, I examine the effects of monetary policy rule on the real properties of business cycles. One difficulty of current analysis is that we do not have consensus on the nature and the size of nominal rigidities. So, I construct several DSGE models in which the nature and the size of nominal rigidities are different. The two sources of nominal rigidities are considered: the nominal wage contract and the price adjustment costs (menu costs) under the monopolistic competition setup. These two sources of real effects of money have been most common ways to introduce nominal rigidities. ${ }^{4}$ For the nominal wage contract model, I consider two cases, oneperiod and multi-period nominal wage contracts to examine the robustness of results under different length of nominal rigidity. For the monopolistic competition model with price adjustment costs, I consider three different sizes of price adjustment costs to examine the robustness of results under different sizes of nominal rigidity. In addition, I construct a model in which these two sources of nominal rigidities coexist to examine the robustness of results under multiple sources of nominal rigidities.

Still the difficulty of analysis is that the magnitude of the effects of monetary policy rules on business cycles is likely to be different depending on the magnitude of rigidity, on which we do not have consensus, either. As a way to have a rough idea on the effects, I compare the changes in business cycle properties under different monetary policy rules with the changes in business cycle properties when we introduce nominal rigidities themselves (and monetary policy

\footnotetext{
${ }^{3}$ For example, Poole [1970] and Sargent and Wallace [1975,1982]. More recently, Aiyagari and Braun [1996], Carlstrom and Fuerst [1995], Chari, Christiano, and Eichenbaum [1995], and Kim [1996]

${ }^{4}$ For example, Cho and Cooley [1995] and Hairault and Portier [1995]. Another popular model is the "liquidity model" as in Lucas [1990], Fuerst [1992], and Christiano, Eichenbaum and Evans [1995]. I plan to) include this model in future work.

${ }^{5}$ Christiano, Eichenbaum, and Evans [1997a] suggested that the model with these two sources of nominal $r$ gidities may produce more reasonable responses to monetary policy shocks.
} 
disturbances) in the model. This comparison seems meaningful since previous researchers introduced nominal rigidities (and monetary policy disturbances) to generate different features of business cycles (which are claimed to be closer to the data), compared to those from the model without money and nominal rigidities. If the changes in business cycle properties under different monetary policy rules are as large as those generated from introducing nominal rigidities, specifying realistic monetary policy rule may be as important as introducing nominal rigidities.

Regarding the policy rule experiments, in addition to the hypothetical monetary polic:y rules with realistic parameterization, I also consider monetary policy rule, which is estimated from data. For this purpose, 1 construct a simplified version of identified VAR models following Sims and Zha [1995] and Christiano, Eichenbaum, and Evans [1996]. As emphasized by Leep $\epsilon$, Sims, and Zha [1996], one of the main achievement of the "identified VAR" literature on identifying monetary policy shocks is the finding of large endogenous reactions of the monetary authority to the state of the economy. Though far simpler than their models, I try to capture some systematic endogenous reactions of the monetary authority to the state of the economy using identified VAR models. Using these estimated monetary policy rules, the direct comparison is possible between the business cycle properties under the AR-1 rule and those under the more realistic monetary policy rule estimated from data. ${ }^{6}$

I also examine the nominal properties of business cycles under different monetary policy rules. As suggested by Gavin and Kydland [1996], monetary policy rules can dramatically affect the nominal features of business cycles. They showed this result using a model where there are

\footnotetext{
${ }^{6}$ In principle, it would be better to (jointly) estimate the whole structure of the model as in Leeper and Sins [1994] and Rotemberg and Woodford [1997] or at least to specify some consistent underlying process for the shocks as in Yun [1996] and King and Watson [1996]. That is, one possible problem is the inconsistency between the identified VAR model used to estimate the monewry policy rule and the DSGE model specifying other structure. One excuse is that we can consider variety of more sophisticated DSCiE models (which we do not have any consensus) without spending too much time on estimation (in contrast to Leeper and Sims [1994]) and without too much simplifying the DSGE model (in contrast to Rotemberg and Woodford [1996]) and without too much simplifying the monetary policy rule (in contrast to Yun [1996]) . I plan to include some experiments which is more consistent.

In most part of the paper, I do not pursue the line of investigation on whether incorporating realistic monetary policy rules can improve the data matching ability of the model or on which model can match the data better since current DSGE monetary business cycle models' overall data matching ability is poor as suggested in King and Watson [1996].

Another issue, which should be discussed, is the definition of the exogenous specification of monetary policy rule. 1 define the exogenous specification of monetary policy rules as the monetary polcy rule which does not react to anything but its own past values (especially not react to other structural shocks). Related to the discussion of Christiano, Eichenbaum, and Evans [1997b], we may specify a realistic monetary policy rule using its own variables and other structural shocks without using any endogenous variables
} 
no nominal rigidities with hypothetical monetary policy rules. Here, I also consider models with nominal rigidities mentioned earlier and my experiments also consider monetary policy rules e:timated from data.

Finally, I discuss some related issues on the effects of monetary policy. The first one is related to the "liquidity effect." It is shown that the postulated monetary policy rule may be critical in deciding the presence of the nominal liquidity effect in some cases. Second, it is suggested that real properties of business cycles under some monetary policy rules could be substantially different even when the effects of monetary policy shocks (or the source of nominal rigidities in the conventional sense) are small.

In Section 2, I construct a variety of DSGE models with different sources and sizes of n'sminal rigidities. In Section 3, I explain monetary policy rules to be considered. In Section 4, I examine the changes in the real properties of business cycles under different monetary policy rules when the productivity shocks are the only disturbances in the economy. In Section 5, I extend the analysis to the cases in which monetary policy shocks are introduced. In Section 6, I e:samine the nominal features of business cycles under different monetary policy rules. In Section 7 , I discuss some related issues on the effects of monetary policy rules on the business cycles. In Section 8 , I summarize the results and conclude.

\section{Models}

\subsection{Common Features of the Model}

The following money demand, money supply equations (the monetary policy rule), the government budget constraint, and the fiscal policy are common features of all models to be cunsidered.

\subsubsection{Monetary Policy Rule}

I assume the following monetary policy rule. 


$$
\begin{aligned}
& \alpha_{\mathrm{h}} \log \frac{\mathrm{M}_{\mathrm{t}}}{\mathrm{M}_{\mathrm{t}-1}}+\alpha_{\mathrm{R}} \log \left(1+\mathrm{r}_{\mathrm{t}}\right)=\log \alpha_{0}+\alpha_{\mathrm{h} 1} \log \frac{\mathrm{M}_{\mathrm{t}-1}}{\mathrm{M}_{\mathrm{t}-2}}+\alpha_{\mathrm{R} 1} \log \left(\mathrm{l}+\mathrm{r}_{\mathrm{t}-1}\right) \\
(2.1)+ & \alpha_{\pi} \log \frac{\mathrm{P}_{\mathrm{I}}}{\mathrm{P}_{\mathrm{t}-1}}+\alpha_{\pi !} \log \frac{\mathrm{P}_{\mathrm{t}-1}}{\mathrm{P}_{\mathrm{t}-2}}+\alpha_{\mathrm{y}} \log \mathrm{Y}_{\mathrm{t}}+\alpha_{\mathrm{y} 1} \log \mathrm{Y}_{\mathrm{t}-1} \\
& +\alpha_{\mathrm{yy}} \log \frac{\mathrm{Y}_{\mathrm{t}}}{\mathrm{Y}_{\mathrm{t}-1}}+\alpha_{\mathrm{yyl}} \log \frac{\mathrm{Y}_{\mathrm{t}-1}}{\mathrm{Y}_{\mathrm{t}-2}}+\log \varepsilon_{\mathrm{ln}}
\end{aligned}
$$

where $\log \varepsilon_{\mathrm{ln}}$ is an i.i.d. $\mathrm{N}\left(0, \sigma_{\mathrm{h}}\right)$ process. I will give more explanations on monetary policy rules in Section 3.

\subsubsection{Money Demand}

Instead of deriving money demand explicitly, I postulate the following money demand equation.

(2.2) $\log \mathrm{M}_{\mathrm{t}}-\log \mathrm{P}_{\mathrm{t}}=\gamma_{\mathrm{c}} \log \mathrm{Y}_{\mathrm{t}}+\gamma_{\mathrm{R}} \log \left(1+r_{\mathrm{t}}\right)+\gamma_{\mathrm{t}}$

where $M_{t}$ is the money stock, $P_{t}$ the price level, $Y_{t}$ real income, $r_{t}$ the nominal interest rate, $\gamma_{c}$ the elasticity of real money balance with respect to income, and $\gamma_{R}$ the semi-elasticity of real mon?y balance with respect to the nominal interest rate. $\gamma_{Y}>0$ and $\gamma_{R}<0$.

By assuming money demand function, we can allow the classical dichotomy in the mocel without nominal rigidities. So, when we introduce a nominal rigidity, all real effects of money are generated from the nominal rigidity. Thus, it helps more clear understanding on the consequence of introducing the nominal rigidity in the model. King and Watson [1996] used a similar strategy.

\subsubsection{Government Budget Constraint and Fiscal Policy}

\footnotetext{
${ }^{7}$ Another reason of postulating the money demand equation instead of deriving it is that the difference in the specific fiunctional form and parameterization of money demand, which may be resulted fiom different way of introducing money in the model, may affect the business cycle properties. I plan to examine tinis issue in the future work. For the results from the transaction cost model, see the previous version of tis paper.
} 
The following government budget constraint and fiscal policy are used for all models. The government budget constraint is:

$$
\frac{M_{t}-M_{t-1}}{P_{t}}+\frac{B_{t}-R_{t-1} B_{t-1}}{P_{t}}+\tau_{t}=0
$$

So, the government finances the total nominal debt $\left(R_{t .1} B_{t .-1}+M_{t-1}\right)$ by issuing new nominal debt $\left(M_{1}+B_{t}\right)$ and collecting lump-sum tax $\left(P_{1} \tau_{t}\right)$. For simplicity, fiscal policy is assumed as $B_{t}=0$.

\subsection{Real Business Cycle Models}

In this model, there are no nominal rigidities, and money does not have any real effects. The real side of the model is one of the standard models in the Real Business Cycle literature, for exínple, King, Plosser, and Rebelo (1988) and Cooley and Prescott (1995). I present the model with nominal variables to be consistent with the notation of the models with nominal rigidities.

The representative household is endowed each period with one unit of time, which he divides between leisure $\left(1-L_{\mathrm{l}}\right)$ and work $\left(L_{t}\right)$. He maximizes his expected lifetime utility subject to his intertemporal budget constraints and the capital stock accumulation technology. There are se veral sources of income - wage income $\left(W_{1} L_{t} / P_{t}\right.$ where $W_{t}$ is nominal wage and $P_{t}$ is the price level), rental income $\left(s_{t} K_{t}\right.$ where $s_{t}$ is real rental rate and $K_{t}$ is capital stock), a constant share of piofits from the firm $\left(P R_{t}\right)$, gross interest income from government bond holdings $\left(\left(1+r_{t-1}\right) B_{t-1} / P_{t}\right)$, where $r_{1 . I}$ is the nominal interest rate of the bonds. He allocates his income to consumption $\left(C_{1}\right)$, investment $\left(\mathrm{L}_{\mathrm{t}}\right)$, changes in money holdings $\left(\left(\mathrm{M}_{\mathrm{t}}-\mathrm{M}_{\mathrm{t}-\mathrm{-}}\right) / \mathrm{P}_{\mathrm{t}}\right)$, government tax $\left(\tau_{t}\right)$, and new purchase of government bonds $\left(B_{1} / P_{t}\right)$. The capital stock evolves as the net result of investment and depreciation (one-period time to build). Thus, each representative household solves the following problem.

$\max _{\left.K_{,}, K_{t}, t, B_{1}\right\}} E_{0}\left[\sum_{t=0}^{\infty} \beta^{t} U\left(C_{t}, 1-L_{t}\right)\right]=E_{0}\left[\sum_{t=0}^{\infty} \beta^{\prime} \frac{C_{t}^{1-\alpha}\left(1-L_{t}\right)^{\alpha}}{1-\sigma}\right]^{1-\sigma} \quad$ s.t.

\footnotetext{
8 There is no loss of generality of this assumption since I am considering only "active monetary - passive fiscal" regime (on which conventional analysis is based) where the Ricardian Equivalence holds. See Cooley and Hansen [1995] pp. 197. Also refer to the next footnote.
} 
(2.4) $\mathrm{C}_{\mathrm{t}}+\mathrm{I}_{\mathrm{t}}+\frac{\mathrm{M}_{\mathrm{t}}-\mathrm{M}_{\mathrm{t}-1}}{\mathrm{P}_{\mathrm{t}}}+\frac{\mathrm{B}_{\mathrm{t}}-\left(1+\mathrm{r}_{\mathrm{t}-1}\right) \mathrm{B}_{\mathrm{t}-1}}{\mathrm{P}_{\mathrm{t}}}+\tau_{\mathrm{t}}=s_{\mathrm{t}} \mathrm{K}_{\mathrm{t}}+\frac{\mathrm{W}_{\mathrm{t}} \mathrm{L}_{\mathrm{t}}}{\mathrm{P}_{\mathrm{t}}}+\mathrm{PR}_{\mathrm{t}}$

(2.5) $\quad \mathrm{K}_{\mathrm{t}}=\mathrm{I}_{\mathrm{t}-1}+(1-\delta) \mathrm{K}_{\mathrm{t}-1}$

where $M_{t} \geq 0$, and $B_{t} \geq 0$.

The first order conditions are:

(2.6) $\frac{d U\left(C_{1}, 1-L_{1}\right)}{d C_{1}}=\lambda_{1}$

(2.7) $\frac{d U\left(C_{1}, 1-L_{1}\right)}{d L_{1}}=\lambda_{1} \frac{W_{1}}{P_{1}}$

(2.8) $\quad \lambda_{\mathrm{t}}=\beta E_{\mathrm{t}} \mathrm{Q}_{\mathrm{r}+1}$

(2.9) $\mathrm{Q}_{\mathrm{t}}=\beta(1-\delta) E_{\mathrm{t}} \mathrm{Q}_{\mathrm{t}+1}+\mathrm{s}_{\mathrm{t}} \lambda_{\mathrm{t}}$

(2.10) $\frac{\lambda_{t}}{\mathrm{P}_{t}}=\beta R_{1} E_{1}\left[\frac{\lambda_{t+1}}{\mathrm{P}_{t+1}}\right]$

Note that $M_{t}$ is determined from pre-specified money demand and money supply equation, so $M_{t}$ is not a choice variable in this problem.

The representative firm maximizes its profits $\left(\mathrm{PR}_{4}\right)$ subject to the production technology.

$\max \quad \mathrm{PR}_{\mathbf{L}} \quad$ s.t.

(2.11) $\quad \mathrm{PR}_{\mathrm{t}}=\mathrm{Y}_{\mathrm{t}}-\mathrm{s}_{\mathrm{t}} \mathrm{K}_{\mathrm{t}}-\frac{\mathrm{W}_{\mathrm{t}} \mathrm{L}_{\mathrm{t}}}{\mathrm{P}_{\mathrm{t}}}$

(2.12) $\mathrm{Y}_{1}=\mathrm{z}_{1} \mathrm{~K}_{1}{ }^{\theta}\left(\mathrm{g}^{\prime} \mathrm{L}_{\mathrm{t}}\right)^{1-\theta}$ 
(2.13) $\log z_{t}=\rho_{z} \log z_{t-1}+\left(1-\rho_{z}\right) \log \bar{z}+\varepsilon_{z t}$

uhere $\vec{z}$ is the steady state value of $z_{1}$ (the technology shock), $\varepsilon_{z 1}$ is an i.i.d $N\left(0, \sigma_{z}\right)$ process, and $\mathrm{g}$ is the steady state growth rate.

The first order conditions are:

(2.14) $\frac{\mathrm{W}_{\mathrm{t}}}{\mathrm{P}_{\mathrm{t}}}=\mathrm{z}_{\mathrm{t}}(1-\theta)\left(\frac{\mathrm{K}_{\mathrm{t}}}{\mathrm{g}^{\mathrm{t}} \mathrm{L}_{\mathrm{t}}}\right)^{\theta} \mathrm{g}^{\mathrm{t}}$

(i.15) $s_{1}=z_{1} \theta\left(\frac{\mathrm{K}_{1}}{\mathrm{~g}^{1} \mathrm{~L}_{1}}\right)^{\theta-1}$

\subsection{Model with Nominal Wage Contract}

In this model, the structure of previous models remains except for the component of predetermined nominal wage contract. Nominal wage is pre-determined, and this is the source of real effects of money. The structure of the model is similar to Cho and Phaneuf [1993] and Bergin [1996] in that the supply side of the labor market set the predetermined wage. Cho and Cololey [1995] and King [1992] also exploit the pre-determined wage setting.

\subsubsection{One-Period Nominal Wage Contract}

I assume that the nominal wage is pre-determined and the equilibrium quantity in the labor market is demand determined. 1 assume that at time $t$, the nominal wage for time $t+l$ is set as the rational expectation of the wage that would prevail at time $t+l$ if the wage is determined in the spot market. These imply substituting the previous labor supply equation (2.7) by the following equation.

(2 16) $\quad \mathrm{W}_{\mathrm{t}}=E_{t-1}\left[\frac{d \mathrm{U}\left(\mathrm{C}_{t}, 1-\mathrm{L}_{\mathrm{t}}\right)}{d \mathrm{~L}_{\mathrm{t}}} \frac{\mathrm{P}_{\mathrm{t}}}{\lambda_{\mathrm{t}}}\right]$ 


\subsubsection{Multi-Period Nominal Contract}

Similarly, I assume that the nominal wage is pre-detennined and the equilibrium quantity in the labor market is demand detennined. I assume that at time $t$, the nominal wages for $t, t+l$, $t+2, t+3$ are set as the rational expectation of the wage that would prevail at those days if the wage is determined in the spot market, which implies the following equations.

$$
\tilde{W}_{t+i, t}=E_{t}\left[\frac{d U\left(C_{t+i}, 1-L_{1+i}\right)}{d L_{t+i}} \frac{P_{i+1}}{\lambda_{t+i}}\right]
$$

where $i=0,1,2$, and 3 and $\widetilde{W}_{t+i, t}$ is the wage at time $t+i$ set at time $t$.

In addition, I assume staggered contracts in which each period one of four contracting groups sets its four-quarter contract. And the overall wage level is approximated by the average over the contract levels of the four groups.

$$
W_{i}=\sum_{i=0}^{3} \frac{1}{4}\left(\widetilde{W}_{t, t-i}\right)
$$

\subsection{Monopolistic Competition Model witb Price Adjustment Costs}

Next model introduces price adjustment costs as the source of nominal rigidity. For the finn to be able to set up the price, the structure of monopolistic competition is assumed. Following Blanchard and Kiyotaki [1987] and Hairault and Portier [1993], I assume CES basket of the different goods and define appropriate price index. Ther, household problem can te described as before. The $\mathrm{j}$ th finn maximizes its value, which is the expectation of the discounted sum of its profit flows. The variables with subscript $j$ imply the variables specific to the $j$ th finr.

$\max \mathrm{PR}_{j 0}=E_{0}\left[\sum_{i=0}^{\infty} \rho_{1} \mathrm{PR}_{\mathrm{n}}\right] \quad$ s.t. 
(219) $\quad P R_{j t}=\frac{P_{j t} Y_{j t}}{P_{t}}-s_{t} K_{1}-\frac{W_{t} L_{j t}}{P_{t}}-A C_{j t}$

(2.20) $\quad P_{j t}=P_{t}\left(\frac{J Y_{j t}}{Y_{t}}\right)^{-\frac{1}{\theta_{y}}}$

(2.21) $\mathrm{Y}_{\mathrm{jt}}=\mathrm{z}_{\mathrm{t}} \mathrm{K}_{\mathrm{jt}}{ }^{\theta}\left(\mathrm{g}^{\mathrm{t}} \mathrm{L}_{\mathrm{jt}}\right)^{\mathrm{t}-\theta}-\Phi \mathrm{g}^{\mathrm{t}}$

(2.22) $\quad \mathrm{AC}_{\mathrm{jt}}=\frac{\phi_{\mathrm{p}}}{2}\left[\frac{\mathrm{P}_{\mathrm{jt}}}{\mathrm{P}_{\mathrm{jt}-\mathrm{i}}}-\frac{\mu}{\mathrm{g}}\right]^{2} \mathrm{Y}_{\mathrm{jt}}$

The equation (2.19) defines the profit where $\mathrm{AC}$ is the adjustment cost. The equation (2.20) is the demand function that the firm $j$ faces, where $J$ is the total number of firms and $\theta_{y}$ is the price elasticity of demand faced by each monopolist. The equation (2.21) describes the production function, where $\Phi$ is the fixed cost component, which allows the firms to earn zero profit in the liong run. The equation (2.22) defines the adjustment cost as a convex function of deviation from the steady state, where $\mu$ is the steady state growth rate of money and $\mu \mathrm{g}$ is the steady state inflation rate. The firm discount factor is given by a stochastic process $\left\{\rho_{\mathrm{t}}\right\}$, which represents a pricing kernel for contingent claims in the equilibrium.

The set of technological restrictions and first order conditions at the aggregate level (by dropping the index of the firm, j) are:

(2.23) $Y_{1}=z_{1} K_{1}{ }^{\theta}\left(g^{\prime} L_{1}\right)^{1-\theta}-\Phi g^{\prime}$

(2.24) $\quad \mathrm{AC}_{\mathrm{t}}=\frac{\phi_{\mathrm{p}}}{2}\left[\frac{\mathrm{P}_{\mathrm{t}}}{\mathrm{P}_{\mathrm{t}-1}}-\frac{\mu}{\mathrm{g}}\right]^{2} \mathrm{Y}_{\mathrm{t}}$

(2.25) $\quad P_{t}=Y_{t}-S_{t} K_{t}-\frac{W_{t} L_{t}}{P_{t}}-A C_{t}$ 
(2.26) $\alpha \mathrm{W}_{1} \mathrm{~L}_{1}=(1-\alpha) \mathrm{s}_{1} \mathrm{~K}_{1}$

$$
\mathrm{s}_{1} \mathrm{~K}_{1}=\alpha\left(\mathrm{y}_{1}+\Phi \mathrm{g}^{\prime}\right)\left(1-\frac{1}{\mathrm{e}_{1}^{\mathrm{y}}}\right)
$$

$$
\mathrm{e}_{1}^{\mathrm{y}}=\theta_{y}\left(1-\phi_{\mathrm{p}}\left(\frac{P_{t}}{P_{t-1}}-\frac{\mu}{g}\right) \frac{P_{t}}{P_{t-1}}\right)+\beta \phi_{\mathrm{p}} E_{t}\left[\frac{\lambda_{t+1}}{\lambda_{1}}\left(\frac{P_{t+1}}{P_{t}}-\frac{\mu}{g}\right)\left(\frac{P_{t+1}}{P_{t}}\right)^{2}\right]
$$

where $e^{y}$ is the output demand elasticity augmented with the adjustment cost.

\subsection{Monopolistic Competition Model with Price Adjustment Costs and Nominal Wage}

\section{Contract}

I also consider another model where the previous two sources of nominal rigidities coexist. I use the structure of the previous monopolistic competition model with price adjustment costs. To incorporate the one-period nominal wage contract, I replace the labor supply equatic n (2.7) with (2.16)

\subsection{Calibration and Solution Method}

Each variable is transforned to real variables and transformed to stationary variables. Then, the system is linearized around the steady state. After the steady state parameters are calibrated, the system is expressed as a first order VAR process without expectational ternis following Sims [1995]. ${ }^{9}$ Impulse responses and Hodrick-Prescott Filtered Population Moments are obtained analytically.

\footnotetext{
${ }^{9}$ For some parameter regions of monetary policy rules, a unique solution cannot be obtained. I exclude those policy rules in my experiments. The estimated monetary policy rules also produce a unique equilibrium. And, by the specification of fiscal rules in my model, I am experimenting the parameter region where monetary policy is "active" and fiscal policy is "passive." (See Leeper [1991]). The possibility of moving to the other region where monetary policy is passive and fiscal policy is active (See Leeper [1993]) and the possibility of other parameter region where there are sunspot equilibria or no solution may he another way that monetary policy may have great effects on the economy.
} 
Parameter values for calibration are chosen so that the steady state values match estimates of average growth rates and specific "great ratios" calculated from the postwar data. Specifically, parameter values (quarterly values) are chosen so that in steady state, $\delta=.025, \theta=$ $.42, R \pi=(1.065)^{25}$, and $I=.2$, following King, Plosser and Rebelo [1988] and King and Watson [1996]. In addition, parameter values implies that $\pi=(1.04)^{25}$ Parameters for productivity shocks, $\rho_{p}$ is set to .95 . Elasticity of real money balance with respect to consumption is set to $1\left(\gamma_{y}=1\right)$, which is the long-run elasticity found in Lucas [1988] and Stock and Watson [1993] and used by King and Watson [1996]. The semi-elasticity of real money balance with respect to the nominal interest rate seems more controversial. The long-run elasticity found in Lucas [1988] and Stock and Watson [1993] is .1. In contrast, Taylor [1993] found larger estimates, .22 of short-run elasticity and 4.73 of long-run elasticity. I used .1. Under different monetary policy rules, in each model, changing the constant term in monetary policy rule preserves the same steady state. For the model of monopolistic competition with price adjustment custs, additional parameterization is needed. Following Hairault and Portier [1993], $\theta_{y}$ is set to 1.197/0.197. Following Rotemberg and Woodford [1995], long run zero profit conditions are imposed. The adjustment cost parameter $\phi_{p}$ is set to $0,1,5$, or 15 . For utility function, $\sigma=1$ is assumed.

\section{Monetary Policy Rules}

In this section, I discuss different monetary policy rules to be experimented. I discuss those rules in relation to the past literature. I rewrite the equation (2.1) again.

$$
\begin{aligned}
& \alpha_{\mathrm{h}} \log \frac{\mathrm{M}_{\mathrm{t}}}{\mathrm{M}_{\mathrm{t}-1}}+\alpha_{\mathrm{R}} \log \left(1+r_{\mathrm{t}}\right)=\log \alpha_{0}+\alpha_{\mathrm{h} 1} \log \frac{\mathrm{M}_{\mathrm{t}-1}}{\mathrm{M}_{\mathrm{t}-2}}+\alpha_{\mathrm{R} 1} \log \left(1+r_{\mathrm{t}-1}\right) \\
&(2.1)+\alpha_{\pi} \log \frac{\mathrm{P}_{\mathrm{t}}}{\mathrm{P}_{\mathrm{t}-1}}+\alpha_{\pi 1} \log \frac{\mathrm{P}_{\mathrm{t}-1}}{\mathrm{P}_{\mathrm{t}-2}}+\alpha_{\mathrm{y}} \log Y_{\mathrm{t}}+\alpha_{\mathrm{y} 1} \log Y_{\mathrm{t}-1} \\
&+\alpha_{\mathrm{y} y} \log \frac{\mathrm{Y}_{\mathrm{t}}}{\mathrm{Y}_{\mathrm{t}-1}}+\alpha_{\mathrm{y} \mathrm{l}} \log \frac{\mathrm{Y}_{\mathrm{t}-1}}{\mathrm{Y}_{\mathrm{t}-2}}+\log \varepsilon_{\mathrm{ht}}
\end{aligned}
$$

The above rule and the following rule, which looks more intuitive, have the same implications on the equilibrium of the linearized system that will be analyzed. 


$$
\begin{array}{ll} 
& \alpha_{\mathrm{h}}\left(\mathrm{H}_{\mathrm{t}}-\overline{\mathrm{H}}\right)+\alpha_{\mathrm{R}}\left(\mathrm{r}_{\mathrm{t}}-\overline{\mathrm{r}}\right)= \\
& (2.29) \quad \alpha_{0}+\alpha_{\mathrm{h}-1}\left(\mathrm{H}_{\mathrm{t}-1}-\overline{\mathrm{H}}\right)+\alpha_{\mathrm{R} 1} \cdot\left(\mathrm{r}_{\mathrm{t}-1}-\overline{\mathrm{r}}\right)+\alpha_{\pi}\left(\pi_{\mathrm{t}}-\bar{\pi}\right)+\alpha_{\pi 1}\left(\pi_{\mathrm{t}-1}-\bar{\pi}\right) \\
& +\alpha_{\mathrm{y}} \cdot\left(\frac{\mathrm{y}_{t} \mathrm{~g}^{\mathrm{t}}-\overline{\mathrm{y}} \mathrm{g}^{\mathrm{t}}}{\overline{\mathrm{y}} \mathrm{g}^{\mathrm{t}}}\right)+\alpha_{\mathrm{y} 1} \cdot\left(\frac{\mathrm{y}_{\mathrm{t}-1} \mathrm{~g}^{\mathrm{t}-1}-\overline{\mathrm{y}} \mathrm{g}^{\mathrm{t}-1}}{\overline{\mathrm{y}} \mathrm{g}^{\mathrm{t}-1}}\right)+\alpha_{\mathrm{yy}} \cdot\left(\frac{\mathrm{Y}_{\mathrm{t}}}{\mathrm{Y}_{\mathrm{t}-1}}-\mathrm{g}\right)+\alpha_{\mathrm{yy} 1} \cdot\left(\frac{\mathrm{Y}_{\mathrm{t}-1}}{\mathrm{Y}_{\mathrm{t}-2}}-\mathrm{g}\right)+\varepsilon_{\mathrm{ht}}
\end{array}
$$

where $\quad \mathrm{H}_{\mathrm{t}}=\mathrm{M}_{\mathrm{t}} / \mathrm{M}_{\mathrm{t}-1}, \quad \pi_{\mathrm{t}}=\mathrm{P}_{\mathrm{t}} / \mathrm{P}_{\mathrm{t}-1}, \quad y_{1} \mathrm{~g}^{\prime}=\mathrm{Y}_{\mathrm{t}}, \quad \alpha_{\mathrm{h}}{ }^{\prime}=\alpha_{\mathrm{h}}, \quad \alpha_{\mathrm{h} 1}{ }^{\prime}=\alpha_{\mathrm{h} 1}, \quad \alpha_{\mathrm{R}}{ }^{\prime}=\alpha_{\mathrm{R}} \overline{\mathrm{H}}$,

$\alpha_{\mathrm{R} 1}{ }^{\prime}=\alpha_{\mathrm{R} 1} \overline{\mathrm{H}}, \alpha_{\pi}{ }^{\prime}=\alpha_{\pi} \overline{\mathrm{H}} / \bar{\pi}, \alpha_{\pi 1}{ }^{\prime}=\alpha_{\pi 1} \overline{\mathrm{H}} / \bar{\pi}, \alpha_{\mathrm{y}}{ }^{\prime}=\alpha_{\mathrm{y}} \overline{\mathrm{H}}, \alpha_{\mathrm{y} 1}{ }^{\prime}=\alpha_{\mathrm{y} 1} \overline{\mathrm{H}}, \alpha_{\mathrm{yy}}{ }^{\prime}=\alpha_{\mathrm{yy}} \overline{\mathrm{H}} / \mathrm{g}$,

$$
\alpha_{\mathrm{yy} 1}=\alpha_{\mathrm{yy} 1} \overline{\mathrm{H}} / \mathrm{g} \text {, and } \varepsilon_{\mathrm{ht}}=\overline{\mathrm{H}}\left(\varepsilon_{\mathrm{ht}}-1\right) \text {. }
$$

Therefore, the monetary authority is assumed to follow a feedback rule. The monetary authority sets money growth rate $\left(\alpha_{h}\right)$ (or interest rate $\left(\alpha_{R}\right)$ or combination of money growth rate and interest rate $\left(\alpha_{h}\right.$ and $\left.\alpha_{R}\right)$ ) in reactions to current and past inflation rate, current and past growth rate of output, current and past level of output, past growth rate of money (current rate also if interest rate setting rule), and past interest rate (current value also if money growth rate setting rule). ${ }^{1011}$

\subsection{Exogenous Monetary Policy Rule}

In the previous literature, the exogenous specification of monetary policy rules is often postulated. In the literature using theoretical models to explore the effects of monetary policy analytically (or in the simple textbook version of monetary policy specification), one of the common specification is the fixed money growth rate rule $\left(\alpha_{h}\right.$ and $\alpha_{0}$ are non-zero constants and other $\alpha^{\text {ss }}$ are zero) In the business cycle models with money, the most common specification Is the AR-1 money growth rate rule ( $\alpha_{h}, \alpha_{h 1}$, and $\alpha_{0}$ are non-zero constants and other $\alpha^{\text {cs }}$ are zero), for example, Cooley and Hansen $(1989,1995)$ In the experiments for the models with only

\footnotetext{
${ }^{10}$ The analysis can be extended to the feedback rule including higher lags. Here, I allow just one lag for simplicity.

"I consider a money growth rate setting rule instead of the level of money setting rule following the tradition within dynamic general equilibrium models, for example, Sargent and Wallace [1982]. In most cases, I consider a money growth rate setting rule instead of an interest rate setting rule to provide direct comparison with commonly specified monetary policy rules in the literature, for example, the AR-1 money growth rate rule or the fixed money growth rate rule.
} 
productivity shocks, I use the fixed money growth rate rule as the benchmark case. In the experiments for the models with both productivity shocks and monetary policy shocks, I use the AR-1 money growth rate rule as the benchmark case.

For the AR-1 money growth rate rule, for the period of 60:1 - 96:4 in the U.S., the estimates of AR-1 coefficient are $.65, .69$, and .72 for $\mathrm{M} 1$, M2, and total reserves, respectively. The positive AR-1 coefficient is also robust for Hodrick-Prescott Filtering. For the filtered छ,rowth rate, the estimates are $.41, .45$, and .38. for $\mathrm{M} 1, \mathrm{M} 2$, and total reserves, respectively. Cooley and Hansen [1995] used this rule with AR-coefficient .491, Cooley and Hansen [1989] with .481, and Cho and Cooley [1995] with .48. I use .41, the estimate from HP-filtered MI growth rate. ${ }^{12}$

\subsection{Hypotbetical Feedback Monetary Policy Rules}

Though most past researchers have used the exogenous specification of monetary policy rules, there has been substantial documentation that monetary authority reacts to the state of the economy to stabilize the economic fluctuations. So, I consider some hypothetical countercyclical, counter-inflation policy rules. I consider a counter cyclical policy with $\alpha_{y y}=-1$, a counter inflation policy with $\alpha_{n}=-.9$, and a counter cyclical-counter inflation policy with $\alpha_{y y}=$ .5 and $\alpha_{\pi}=-.5$. I also consider a pro-cyclical policy with $\alpha_{y y}=1$.

\subsection{Estimated Monetary Policy Rules}

In addition to hypothetical counter-cyclical and counter-inflation monetary policy rules, I consider the monetary policy rules estimated from data. I follow the VAR literature identifying nonetary policy shocks. I simplify the models of Sims and Zha [1995] and Christiano, E.ichenbaum, and Evans [1996].

I include four variables in the VAR system - treasury bill rate (TBR), MI growth rate ( $\mathrm{Mlg}$ ), real GNP growth rate (RGNPg), GNP deflator growth rate (PGNPg). I used only one-lag. The estimation period is from 1960-1996 using US quarterly data. ${ }^{13}$

Another reason 1 used money growth rate setting rule instead of interest rate setting rule is that the f xed interest rate rule generates indeterminacy problem under the commonly specified fiscal regime and it is difficult to use it as a benchmark case. I plan to consider interest rate setting rule in the future work.

${ }^{12}$ I also report the estimates of the standard deviation of monetary policy shocks $\left(\sigma_{h}\right)$ from the AR-1 rule. The estimates are $.0081, .0061$, and .0047 for non-H-P-filtered M1, M2, and MB, respectively. For H-P filtered series, they are $.0075, .0045$, and .0038 , respectively. I used .0075 .

13 I used HP-filtered data. 
The first one is a simplified and modified version of Christiano, Eichenbaum, and Evans [1996] (the CEE rule), 1 used a recursive system where the ordering is RGNPg, PGNPg, M g, and TBR. That is, monetary authority is assumed to set current Mlg after observing current and lagged RGNPg, PGNPg and lagged Mlg and TBR. The other one is a simplified and modified version of Sims and Zha [1995] (the SZ rule), monetary authority is assumed to set current Mlg after observing current and lagged TBR and lagged RGNPg, PGNPg, and Mlg. For the other structures of the SZ, PGNPg and RGNPg equations are assumed to a block, which is contemporaneously exogenous to other variables, and TBR equation is assumed to include all variables contemporaneously. ${ }^{14}$

The estimated parameters for the CEE rule is:

$$
\begin{aligned}
\mathrm{Mlg}= & -.000061-.15 \mathrm{PGNPg}_{\mathrm{t}}+.019 \mathrm{RGNPg}_{\mathrm{t}} \\
& -.32 \mathrm{TBR}_{t-1}+.21 \mathrm{Mlg}_{t-1}-.090 \mathrm{PGNPg}_{t-1}-.16 \mathrm{RGNPg}_{t-1}, \sigma_{\mathrm{h}}=.0071
\end{aligned}
$$

The estimated parameters for the $\mathrm{SZ}$ rule is:

$$
\begin{aligned}
\mathrm{Mlg}= & .000022-.051 \mathrm{TBR}_{\mathrm{t}} \\
& -.34 \mathrm{TBR}_{\mathrm{t}-1}+.21 \mathrm{Mlg}_{\mathrm{t}-1}-.070 \mathrm{PGNPg}_{t-1}-.18 \mathrm{RGNPg}_{\mathrm{t}-1}, \sigma_{\mathrm{h}}=.0066
\end{aligned}
$$

Since some previous research suggested that the monetary policy rules for the period before the October 1979 and after the October 1979 are different, I also estimate for the period of 79:4 - 96:4. The estimated parameters for the CEE rule is:

$$
\begin{aligned}
\mathrm{Mlg}= & -.000023+.38 \mathrm{PGNPg}_{\mathrm{t}}+.10 \mathrm{RGNPg}_{\mathrm{t}} \\
& -.40 \mathrm{TBR}_{\mathrm{t}-1}+.19 \mathrm{Mlg}_{\mathrm{t}-1}-.068 \mathrm{PGNPg}_{t-1}-.27 \mathrm{RGNPg}_{t-1}, \sigma_{\mathrm{h}}=.0081
\end{aligned}
$$

The estimated parameters for the $\mathrm{SZ}$ rule is :

$$
\begin{aligned}
\mathrm{Mlg}= & -.000046+.20 \mathrm{TBR}_{t} \\
& -.24 \mathrm{TBR}_{t-1}+.21 \mathrm{Mlg}_{t-1}+.21 \mathrm{PGNPg}_{t \cdot t}-.27 \mathrm{RGNPg}_{t-1}, \sigma_{\mathrm{h}}=.0081
\end{aligned}
$$

\footnotetext{
${ }^{14}$ The implications are the same when the interest rate setting rule instead of the money growth rate seting rule is postulated for the $\mathrm{SZ}$ rule.
} 


\section{Effects of Monetary Policy Rules on the Real Properties of Business Cycles: Productivity}

Shocks

In this section, I examine the effects of monetary policy rules in the simplest environment where the only disturbances in the economy are productivity shocks. The benchmark monetary policy rule for comparison is the fixed money growth rate rule. I consider different feedback rules on the growth rate of output and inflation rate.

First I report the real properties of business cycles for the U.S. in Table 1. As suggested b) many researchers, investment is more volatile than GNP, working hours, and wage while consumption is less volatile than GNP. These variables are highly pro-cyclical and highly persistent.

In Table 2, 1 report the business cycle properties of the different models under the constant money growth rate rule. I consider eight different models - the real business cycle misdel (RBC), the one-period nominal wage contract model (NWC-1), the multi-period nominal witge contract model (NWC-M), the monopolistic competition models without price adjusin ents cost (MC-0) and with price adjustment costs of $\phi_{\mathrm{p}}=1,5$, and 15 (MC-1, MC-5, and MC-15, respectively) and with price adjustment costs of $\phi_{p}=5$ and one period nominal wage contract (MIC-5-NWC-1).

These models can reproduce some important real features of business cycles. These models generate pro-cyclical and highly persistent behavior of each variable. These models can reproduce the rankings of relative volatility - investment is more volatile than output and other variables are less volatile than output. ${ }^{15}$ In details, these models produce somewhat different properties of business cycles. For example, when the nominal rigidities are introduced, volatility of investment, output, consumption decreases (compare (1) with (2) and (3), and (4) with (5), (6), (7), and (8)). We can see this property more clearly in (1) of Tables 3 and 4 . Here, I do not pursue further analysis on the relative successes and failures of these models.

In Tables 3 and 4, 1 report the changes in population moments under different monetary policy rules. I consider feedback rules on growth rate of output and inflation rate. First, I consider a counter-cyclical policy $\left(\alpha_{h}=1, \alpha_{y y}=-1\right)$ that increases $1 \%$ in growth rate of money from its steady state in response to $1 \%$ decrease in output growth rate from its steady state. ((2) in Tables 3 and 4) Second, I consider a pro-cyclical policy $\left(\alpha_{h}=1, \alpha_{y,}=1\right)$ that decreases $1 \%$ in growth rate of money in response to $1 \%$ decrease in output growth rate from its steady state ((3) 
in Tables 3 and 4). This monetary policy rule may be interpreted as a monetary accommodation to cyclical behavior of output to stabilize inflation under productivity shocks. When there is a negative productivity shocks, by decreasing money growth rate, the monetary authority cain stabilize the inflation from the negative productivity shocks. Third, I consider a counter-inflation policy $\left(\alpha_{n}=1, \alpha_{\pi}=-9\right)$ that decreases $1 \%$ in growth rate of money in response to $.9 \%$ increase in inflation rate from its steady state ((4) in Tables 3 and 4).

I also report the changes in business cycle properties when we introduce nominal rigidities under the constant growth rate rule to have some idea on the size of the changes in business cycles under different monetary policy rules $((1)$ in Tables 3 and 4) Note that the changes are compared to the model without nominal rigidities under the same monetary policy rule (the constant money growth rate rule). For example, two nominal wage contract models are compared to the RBC model and the monopolistic competition models with price adjustment costs $\left(\phi_{p}=1,5\right.$, and 15) and the MC-5-NWC-1 model are compared to the monopolistic competition model without price adjustment costs $\left(\phi_{P}=0\right)$.

In most cases, we can find some changes in standard deviation of each variable. Sometimes, the changes are substantial and even the ranking of volatility changes. ("*' represerts the change in ranking.) We can also find some changes in the correlation structure.

The changes in business cycle properties under different rules are considerable. In the cases of the counter-cyclical policy and counter-inflation policy, we find relatively small changes in business cycle properties. Even in this case, we cannot say that it is of a second-order importance compared to the changes generated from introducing nominal rigidities. In the case of the accommodative inflation-stabilizing policy, the changes in the business cycle properties under different monetary policy rules are as large as the changes generated from introducing nominal rigidities. In the case of nominal wage contract models, the changes are even larger. In the case of monopolistic competition models, we can find a similar size of the changes.

We can find one interesting pattern of the sign changes. In the case of the inflationstabilizing accommodative policy and the counter-inflation policy, the direction of the changes is the opposite to those generated from introducing nominal rigidities in most cases. That is, the numbers in (1) have the opposite signs of the numbers in (3) and (4). In contrast, in the case of counter cyclical policy, we do not find this tendency, and rather, the direction of the changes is similar.

\footnotetext{
is The exception is the MC-15 model for the labor movements.
} 
I give an interpretation on this result. By introducing nominal rigidities, fluctuations of real variables are dampened. (We can see this from decreases in standard deviations of most variables in (1)) Due to the nominal rigidity, the economy cannot exploit all the opportunity given by productivity increases compared to the case without nominal rigidities. Now the only structural shocks are the productivity shocks. Counter-cyclical policy will further reduce the fluctuations of real variables, so we observe the similar direction of the changes. However, ccunter-inflation policy or inflation stabilizing policy will increase the fluctuations of real variables toward the initial level. One interesting case is the accommodative inflation stabilizing policy for the monopolistic competition models. In these models, the size of two changes are alnost the same, that is, almost all changes generated from introducing price adjustment costs are off set by assuming the accommodative inflation stabilizing policy.

In summary, I experimented with various monetary policy rules for different models under productivity shocks. The major result is that changes in monetary policy rule can generate changes in real features of business cycles as much as introducing nominal rigidities. Note that the experiments involve hypothetical, but sensible parameter values of monetary policy rules.

\section{Introducing Monetary Disturbances: How reasonable is the AR-1 Money Growth Rate Rule as an Approximation to the Realistic Monetary Policy Rule?}

In this section, I examine the changes in the business cycle properties under different monetary policy rules when monetary policy disturbances are introduced. In these experiments, I use the AR-1 money growth rate rule with stochastic disturbances as the benchmark case. I report the business cycle properties under these benchmark cases in Table 5. These models again can explain relative volatility of each variable to output, and pro-cyclical behavior and high pe:rsistency of each variable.

In Tables 6-11, I report the changes in business cycle properties under different monetary policy rules. I consider the counter-cyclical policy ((3) of each table, $\left.\alpha_{\mathrm{h}}=1, \alpha_{y y}=-1\right)$, the counterinflation policy ((4), $\left.\alpha_{h}=1, \alpha_{n}=-.9\right)$, the counter-cyclical-counter-inflation policy ((5), $\alpha_{h}=1, \alpha_{n}=-$ $.5, \alpha_{y y}=-5$ ), the SZ rule (6), the CEE rule (7), and the SZ rule (estimated for the period from 79:4) (8). In addition, for comparison, I report the changes in the business cycle properties when nominal rigidities and monetary policy shocks (with the AR-1 rule) are introduced in (1) of each table. That is, I compare the model of nominal rigidities under the AR-1 rule (with monetary disturbances) to the models of no nominal rigidities under the fixed money growth rate rule 
(without monetary disturbances). For example, the NWC-I and the NWC-M models under the AR-1 rule with monetary disturbances are compared to the RBC model under the fixed money growth rate rule without monetary disturbances. I also report, given the nominal rigidity, the changes in the business cycle properties when the monetary disturbances are introduced with the AR-1 rule in (2) of each table. That is, I compare the same model of nominal rigidities under the fixed money growth rate rule without monetary disturbances and under the AR-l rule with monetary disturbances.

From (2) of each table, we can see that standard deviations of each variable increases in most cases when monetary disturbances are introduced with the AR-1 rule in the model of nominal rigidities. This seems reasonable since another source of disturbances, that is, monetary policy shocks, (which is amplifiod by the AR-1 rule with the positive coefficient) can generate more volatility of each variable. In addition, correlations and autocorrelations decrease in most cases. This is not surprising since the introduction of monetary disturbances in the model with nominal rigidities will blur the high correlation and autocorrelation structure generated from the productivity shocks. These effects also seem to be amplified by the AR-1 rule with the positive coefficient.

When we consider the changes from introducing nominal rigidities in addition to the changes from introducing monetary disturbances with the AR-1 rule (in (1) of each table), we can find some reduction of changes in the standard deviations. As we suggested in the Section 4 , introduction of nominal rigidities reduces the standard deviations in general. Therefore, the direction of the changes in standard deviations is mixed. The changes in the correlation structure become more complicate reflecting these two effects.

Now we examine the changes from the AR-1 rule to the other policy rules. In mar:y cases, the standard deviation of each variable decreases. In the monopolistic competition models with larger nominal rigidities (the MC-5, the MC-I5, and the MC-5-NWC-I models), the standard deviations of all variables decrease. In the other models, we also find the decrease in many cases. This may suggest the stabilization role of the realistic policy rules, which is not incorporated in the AR-1 rule. Another interesting pattern is found. The sign of changes in ( $\Sigma$ ), (6), (7), and (8) are very similar. This also suggests the realistic policy rule seems to be the inflation and output stabilization policy.

Next we examine the size of the changes from the AR-1 rule to the other policy rules. The changes are substantial in some cases. Sometimes, the standard deviation changis substantially and the volatility ranking changes. In some cases, the correlation and 
autocorrelation structure change substantially. The size of these changes are comparable to those generated from introducing monetary disturbances with the AR-1 rule (in (2) of each table) and fom introducing monetary disturbances with the AR-1 rule and the nominal rigidities (in (1) of e:sch table).

In summaty, we can generalize the previous findings - changes in monetary policy rule can generate changes in the real features of business cycles as much as introducing nominal rigidities and monetary disturbances. Compared to the previous section, our experiments also consider monetary policy rules estimated from data in addition to some hypothetical policy with sensible parameterization.

Another interesting implication is that the AR-1 rule may not be a very good approximation to the realistic monetary policy rule. This failure of the AR-1 rule seem to be atribute to the lack of consideration of the monetary authority's systematic stabilization, which stems to be better approximation to the real world. Instead, the exogenous monetary policy rule such as the AR-1 rule cannot incorporate any stabilization role on other structural shocks and exaggerate the effects introducing monetary disturbances (with positive AR-I coefficient). Though it is difficult to conclude the exact magnitude of the failure of the AR-1 rule, the size of failure could be large in the model with larger nominal rigidities. For example, the experiments suggest that in the case of MC-5 model, the differences are $.35-.38 \%$ of the labor volatility, .42 $.79 \%$ of the investment volatility, $.08-.21 \%$ of output volatility, $0.01-0.21$ of autocorrelation of output, and .15-.21 of autocorrelation of labor.

\section{Nominal Features of Business Cycles}

In this section, I examine business cycle properties of nominal variables under different monetary policy rules. In Table 12 (a), I report standard deviations of inflation, nominal interest rate, and the growth rate of money, and the correlation of these variables with output in the U.S. Nominal interest rate is more volatile than the growth rate of the money and inflation. The growth rate of money is more volatile than inflation rate. Inflation and nominal interest rate are pro-cyclical while the growth rate of money is counter-cyclical. ${ }^{1617}$

\footnotetext{
${ }^{16}$ As will be suggested in Section 7, examining correlation between nominal variables may be also in:eresting. I plan to include these experiments in the next version.

${ }^{17}$ One interesting correlation is counter-cyclical behavior of growth rate of money. This correlation is difficult to be explained by exogenous money growth rate rule since monetary policy shocks will generate pcisitive correlation under nominal rigidities and other structural shocks will generate zero correlation.
} 
In Table 12 (b), I report the standard deviations and the correlation with the output for the different models under different monetary policy rules. The models and policy rules under consideration are the same as in Section 5 (with monetary disturbances). I do not report the results for the experiments in Section 4 since these standard deviations and correlations seem very unrealistic without monetary disturbances even though the changes are even more dramatic in this case.

We can see that the ability of these models to match the movements of the nomiral variables is questionable in general. ${ }^{18}$ The standard deviation of inflation rate is too high compared to the data while the standard deviation of money is too low. Correlation of inflation and output is negative in the nominal wage contract models and the models with small nomiral rigidities (RBC, MC-1, MC-0). However, these models still can generate similar magnitude of standard deviation of the growth rate of the money and positive correlation of nominal interest rate and output. Monopolistic Competition models with larger price adjustment costs can generate positive correlation of inflation rate and output. Some models can produce reasonable values of standard deviation of inflation rate and negative correlation of money growtl. rate and output. And a few models can generate higher standard deviation of nominal interest rate and output. Again, I do not further investigate which models can match the data better relatively.

In many cases, business cycle properties of nominal variables change substantially uncer different monetary policy rules as suggested by Gavin and Kydland [1996] using the moriel without nominal rigidities under hypothetical policy rules. Here, their results are extended to the models with nominal rigidities and the policy rules estimated from data. ${ }^{19}$ For example, the standard deviation of inflation under the counter-cyclical policy is three times bigger than these under the counter-inflation policy in the RBC and the MC-0 models. (The difference in absolute values is $1.5 \%$, and the AR-1 rule is in between.) As an another example, in the NWC-M model, the correlation of nominal interest rate and output under the counter-cyclical policy is 0.05 while it is 0.60 under the counter-inflation policy.

In addition, the business cycle properties of nominal variables under the AR-I rule are often substantially different from those under the more realistic monetary policy rule. In general,

These negative correlation seem suggest that counter-cyclical role of monetary policy. We do find smaller positive correlation, indeed negative in some cases, under more realistic monetary policy rules.

${ }^{18} \mathrm{King}$ and Watson [1996] suggested that current monetary business cycle models cannot match all dimensions of business cycle properties in the data.

${ }^{19}$ One interesting result related to Gavin and Kydland [1996] is that the changes in nominal features seems to become smaller for the model with nominal rigidities. In many cases, the changes are greater in the $\mathrm{R} 3 \mathrm{C}$ 
compared to those under the AR-I rule, the standard deviation of inflation, nominal interest rate, ard the growth rate of money decrease, correlation of output and inflation becomes smaller. ${ }^{20}$ As ar extreme example, in the MC-5-NWC-1 model, 0.25, a positive correlation of inflation and output under the AR-1 rule changes to very small number or even negative under other monetary policy rules, some of which are more realistic than the AR-1 rule. As an another example, in the NWC-1 model, 0.75 of the standard deviation of nominal interest rate under the AR-1 rule decreases substantially to less than 0.10 under the $\mathrm{SZ}$ rule.

These results also suggest some caution to the monetary business cycle researchers troing to match nominal features of business cycles under the simple exogenous specification of monetary policy rules such as the AR-1 rule. Using the previous example of the MC-5-NWC-1 m.del, the researcher using the AR-I rule may argue that the MC-5-NWC-I model can match the pesitive correlation of inflation and output. However, if he specifies more realistic monetary pclicy rule, for example, the SZ (79:4-) rule, the correlation is -0.01 , which is substantially different from the previous positive correlation. Of course, there are some more robust features that the properties are not much different under the AR-1 rule and under the realistic monetary pclicy rule. But it would be better to specify the realistic monetary policy rule, rather than re ying on the plain luck.

\section{Other Experiments}

In this section, I list two interesting cases where monetary policy rule may affect the business cycle properties substantially. The first one is related to the nominal liquidity effect, the eff'ects on the nominal variable. The second one is related to effects on the real variables.

\section{1) Liquidity Effects and Inflation Expectation}

Many previous researchers try to find the liquidity effect of monetary policy shocks in the theoretical model with the money. (For example, King [1992] and King and Watson [1996])

model and the MC-0 model where there are no nominal rigidities, compared to those in the other models wih nominal rigidities.

${ }^{20}$ Again, the decrease in the standard deviation of inflation and the correlation of output and inflation suggest stabilizing role of realistic monetary policy rule which is not incorporate din the AR-1 rule. Hcwever, decrease in nominal interest rate and growth rate of money are somewhat difficult to explain since mcnetary authority may increase volatility of these instruments to stabilize inflation. We may have better explanation by incorporating money demand disturbances or financial market disturbances. 
Here, I suggest that the presence of the liquidity effects may critically depend on the specification of monetary policy rule.

In Figure 1, I report the impulse response to monetary policy shocks under different monetary policy rules for the RBC model. I consider the fixed money growth rate rule (fixed $\mathrm{Mq}$ ), the AR-1 rule, the pro-inflation policy which increases $1 \%$ of the growth rate of money in response to the $1 \%$ increase in the lagged inflation rate (laginf $=.42$ ), the counter-inflation policy which decreases $1 \%$ of the growth rate of money in response to the $1 \%$ increase in the lagged inflation rate (laginf=-.42), the SZ rule, and the CEE rule. Each line is the responses to the $1 \%$ changes in the growth rate of the money in the case of the fixed money growth rate rule, the AR-1 rule, the pro-inflation policy, and the counter-inflation policy. For the responses under the $\mathrm{SZ}$ and the CEE rules, I adjust the size of the shocks, using the relative size of estimated standard deviation of monetary policy shocks."

As easily seen in the Figure, the responses of nominal interest rate are different under different monetary policy rules. Under the fixed money growth rate rule, the nominal interest rate does not respond at all since in this flexible price model, the price level adjust instantaneously, the inflation expectation is zero. Under the AR-1 rule, due to the increase in inflation expectaticn (from future increases in the growth rate of money), the nominal interest rate is above its steady state. That is, we find the opposite case of the liquidity effect. Next, I consider the pro-inflation policy on the lagged inflation rate, the responses are very similar to the AR-1. The increase in the growth rate of money today increases inflation today, and on the next date monetary authori:y increases money growth rate again following the feedback rule, then in the next period, there is inflation..... So, the responses of money growth rate and inflation are similar to the AR-1 rule case, and rational economic agents expect these future events, and the nominal interest rate increases.

Then, it is not so difficult to generate the nominal liquidity effect. All we need is to specify a monetary policy rule generating decrease in the future growth rate of money arid deflation expectation under a positive money growth rateshock. The counter-inflation policy with lagged inflation rate is one case. The increase in the growth rate of money today increases inflation today, and the next date monetary authority decreases money growth rate following the feedback rule, then in the next period, there is deflation. This deflation expectation decreases the nominal interest rate today, and under this feedback rule, we do find the liquidity effect.

\footnotetext{
"2 In fact, this adjustment does not play much role since the magnitude of the standard deviation is not much different under the AR-1 rule and the SZ or the CEE rules.
} 
Then, what are the responses under the rules estimated from data? In the graphs for the $\mathrm{SZ}$ and the CEE rules, we do not find the liquidity effect. But note the response of inflation. It sharply drops in the next period (compared to the AR-1 rule), the magnitude of increase in the nominal interest rate is far smaller than the AR-I rule case. This suggests that the AR-1 specification may exaggerate the positive response of interest rate and the absence of the liquidity effect. I further pursue this possibility in the model with nominal rigidities and I report one example in which the liquidity effect is found under the $\mathrm{SZ}$ and the CEE rules but not under the AR-1 rule. I report the graph in the Figure $2 .{ }^{22}$

I also did some experiments with these lagged inflation rate rule. In some cases, the changes in nominal features of business cycles, for example the correlation of nominal interest rate and inflation, could be very much different under this kind of rule.

This experiment shows that private agent's expectation on monetary authority's stabilization can feed into the effects of monetary policy shocks, in particular, the liquidity effect.

2) Feedback rules on the Level of Output and the Productivity Shocks

Now I consider another feedback rule that the monetary authority changes the growth rate of money in response to the changes in the level of output. Under this feedback rule, the transmission of productivity shocks substantially change even when the effects of monetary policy shocks are small.

In Figure 3, I report the impulse responses to monetary policy shocks in the MC-1 model. In response to $1 \%$ increase in the growth rate of money, investment increases about $.6 \%$, output increases .2\%, and labor increases $.3 \%$, and consumption increases less than $.015 \%$. The increases in output, investment and labor go back to the level close to the initial level very soon. That is, the real effect of monetary policy shocks are relatively small and short-lived. In the conventional tern, the nominal rigidity in this model is small.

In Figure 4, I report the impulse responses to productivity shocks. ' + ' lines are the responses in the MC-1 model (with nominal rigidities) under the fixed money growth rate rule ard dotted lines are the responses in the MC- 0 model (without nominal rigidities) under the fixed money growth rate rule. We can see that there are only small differences, especially for the inipact effect on the investment, labor, and output. Again, we may suggest that the nominal rigidity in the model is small.

\footnotetext{
${ }^{22}$ To generate the nominal liquidity eff ect, 1 introduce the large ad justment costs to the investment.
} 
In Figure 4, I also report the impulse responses to productivity shocks in the MC-1 model under the feedback rule on the level of output (the solid line). The parameter values are $\alpha_{h}=1$ and $\alpha_{y}=-1$, that is, the monetary authority increases the growth rate of money by $1 \%$ in response to $1 \%$ decrease in the level of output from its steady sate. The differences are quite substantial compared to either the magnitude of the effects of monetary policy shocks or the magnitude of the effects of introducing nominal rigidities. The differences to the same model under the fixed money growth rate rule are $2 \%$ for the investment, $.4 \%$ for the output, and $.7 \%$ for the labor. And the differences last for the very long period. The consumption movements is more striking. The difference in the consumption movements is $3 \%$ at the peak, which is more than 20 times greater than the effects of monetary policy shocks on consumption.

In fact, this dramatic changes in the transmission of productivity shock is not very surprising if we see the impulse responses of the growth rate of money under the feedback rule. When there is a productivity shock, output level is above its steady state for a long time, which generates prolonged decreases in the growth rate of money. These prolonged decreases in the growth rate of money generate the huge difference in the transmission of the productivity shocks.

Though these huge differences are not very surprising once we see the impulse responses of the growth rate of the money, this experiment suggests that real properties of business cycles may change substantially under some monetary policy rules even in the case where nominal rigidities are small (in conventional tern) so that monetary policy shocks have small effects on real variables.

\section{Conclusion}

By constructing a variety of DSGE models, I examine the business cycle properties under different monetary policy rules. Different monetary policy rules generate substantially different nominal features of business cycles. Further, different monetary policy rules can generate somewhat different real features of business cycles. It is difficult to conclude what is the exact size of changes in business cycle properties under different monetary policy rules since the exact size depends on the nature and the size of rigidities in the economy, which we do not have clear idea. However, the changes in the real properties of business cycles under different monetary policy rules are as large as (or even larger than) the changes generated from introducing rigidities themselves (and monetary policy shocks). 
These changes in the business cycle properties are examined under sensible values of parameters in the monetary policy rules including the monetary policy rules estimated from data vsing the identified VAR models. The exogenous specification of monetary policy rules, the AR-1 r.ile in particular, does not incorporate monetary authority's systematic reactions to the state of economy as a stabilization. As a result, the AR-1 money growth rate rule exaggerates the effects f.om introducing nominal rigidities and monetary policy disturbances and the transmission of froductivity shocks. Therefore, the business cycle properties under the realistic monetary policy rules and those under the AR-1 rule are quite different, and the AR-1 rule, which has been fequently postulated by past researchers, does not seem to be a good approximation to the realistic monetary policy rules. ${ }^{23}$

Other interesting findings are: first, the specification of monetary policy rules may critically affect the presence of the nominal liquidity effect in some cases. A counter-inflation nonetary policy may lead to reductions on expected inflation which may help generating the rominal liquidity effect. The inflation stabilizing policy may form the deflationary expectation inder the expansionary monetary policy shocks, which may helpgenerating the nominal liquidity effect. Second, even in the case of small nominal rigidity in the conventional term (when the effects of monetary policy shocks are small), real properties of business cycles under some monetary policy rules may be substantially different. Some monetary pulicy rules inay generate large and persistent deviations in growth rate of money, so the resulting transmission mechanism cf structural shocks may be substantially different.

All these results suggest that, by adopting different monetary policy rules, monetary authority seems to have the potential to affect the real economy substantially ${ }^{24}$ and that incorporating realistic monetary policy rules allowing endogenous reaction to the state of the economy is important for monetary business cycle research.

\footnotetext{
${ }^{23}$ This result seems to be inconsistent with Yun [1996], which suggested monopolistic competition models r an better explain positive output-inflation correlation regardless of endogenous or exogenousmoney supply iules. First, he concentrated on one feature of business cycle properties. As suggested in Section 6, there may he some robust features that do not depend much on the monetary policy rule. However, some features do depend on the monetary policy rule. Second, his endogenous money supply may not capture much of $\epsilon$ ndogenous reaction of the monetary authority due to simple specification or due to money demand relation that he do not separate. In the impulse responses graphs, technology shocks are more destabilizing under endogenous monetary policy rule compared to under exogenous policy rule.

${ }^{26}$ These results are not necessarily inconsistent with findings of Sims and Zha [1995] and Kim [1995]. Monetary policy rules considered here are similar to "dramatic" changes in monetary policy rule considered hy those studies. Those studies suggested that monetary authority has the potential to affect real economy substantially by changing monetary policy rule dramatically.
} 
Table 1. Cyclical Behavior of the U.S. Economy: Deviations from Trend of Key Variables: 60:1-96 4

\begin{tabular}{|l|l|l|l|l|l|l|l|l|}
\hline \multirow{2}{*}{ Variable } & SD & \multicolumn{7}{|l|}{ Cross-Correlation of Output (t-j) } \\
\cline { 2 - 10 } & $\%$ & -3 & -2 & -1 & 0 & 1 & 2 & 3 \\
\hline Investment & 7.62 & .46 & .62 & .77 & .88 & .75 & .54 & .30 \\
\hline GNP & 1.48 & .48 & .70 & .88 & 1.0 & .88 & .70 & .48 \\
\hline Hours & 1.30 & .33 & .55 & .76 & .90 & .89 & .76 & .60 \\
\hline Wage $^{\star}$ & 0.76 & .47 & .58 & .66 & .68 & .59 & .46 & .29 \\
\hline Cons (ND)* & 0.86 & .55 & .68 & .78 & .77 & .64 & .47 & .27 \\
\hline
\end{tabular}

* reproduced fiom Cooley and Prescott [1995] (54:1-91:2) 
Table 2. Benchmark Models: Constant Money Growth Rate Rule $\left(\alpha_{h}=1\right)$

(1) Real Business Cycle Model

\begin{tabular}{|c|c|c|c|c|c|c|}
\hline Var. & SD & Rank & \multicolumn{2}{|c|}{ Corr. With y $(t+j)$} & Auto \\
\cline { 3 - 6 } & $\%$ & SD & -1 & 0 & $I$ & 1 \\
\hline Inv. & 3.80 & 1 & 0.67 & 0.99 & 0.74 & 0.71 \\
\hline Y & 1.39 & 2 & 0.72 & 1.00 & 0.72 & 0.72 \\
\hline L & 0.83 & 3 & 0.64 & 0.98 & 0.74 & 0.71 \\
\hline W & 0.61 & 4 & 0.78 & 0.96 & 0.64 & 0.77 \\
\hline C & 0.43 & $S$ & 0.78 & 0.87 & 0.54 & 0.82 \\
\hline
\end{tabular}

(3) Multi-Period Nominal Wage Contract

\begin{tabular}{|c|c|c|c|c|c|c|}
\hline Var. & SD & Rank & \multicolumn{2}{|c|}{ Corr. With y $(++j)$} & Auto \\
\cline { 4 - 6 } & $\%$ & SD & -1 & 0 & 1 & 1 \\
\hline inv. & 3.08 & 1 & 0.75 & 0.99 & 0.80 & 0.78 \\
\hline y & 1.16 & 2 & 0.78 & 1.00 & 0.78 & 0.78 \\
\hline I & 0.60 & 3 & 0.78 & 0.80 & 0.60 & 0.82 \\
\hline w & 0.50 & 4 & 0.84 & 0.94 & 0.67 & 0.85 \\
\hline c & 0.39 & 5 & 0.79 & 0.91 & 0.64 & 0.82 \\
\hline
\end{tabular}

(5) Monopolistic Competition with Price Adjustment Costs ( $\phi_{D}=1$ )

\begin{tabular}{|c|c|c|c|c|c|c|}
\hline Var. & SD & Rank & \multicolumn{3}{|c|}{ Corr. With $y(t+j)$} & Auto \\
\cline { 4 - 7 } & $\%$ & SD & -1 & 0 & 1 & I \\
\hline inv. & 3.56 & 1 & 0.77 & 0.99 & 0.81 & 0.80 \\
\hline y & 1.42 & 2 & 0.79 & 1.00 & 0.79 & 0.79 \\
\hline I & 0.52 & 5 & 0.89 & 0.92 & 0.74 & 0.86 \\
\hline w & 0.67 & 3 & 0.83 & 0.97 & 0.72 & 0.82 \\
\hline c & 0.56 & 4 & 0.79 & 0.94 & 0.68 & 0.79 \\
\hline
\end{tabular}

(7) Monopolistic Competition with Price Adjustment Costs $\left(\phi_{D}=15\right)$

\begin{tabular}{|c|c|c|c|c|c|c|}
\hline Var. & SD & Rank & \multicolumn{3}{|c|}{ Corr. With y(t+j) } & Auto \\
\cline { 4 - 6 } & $\%$ & SD & -1 & 0 & 1 & 1 \\
\hline inv. & 1.80 & 1 & 0.98 & 0.91 & 0.77 & 0.91 \\
\hline y & 0.67 & 3 & 0.95 & 1.00 & 0.95 & 0.95 \\
\hline I & 1.22 & 2 & 0.41 & 0.09 & -0.15 & 0.62 \\
\hline w & 0.30 & 5 & 0.91 & 0.96 & 0.89 & 0.92 \\
\hline c & 0.41 & 4 & 0.36 & 0.62 & 0.75 & 0.64 \\
\hline
\end{tabular}

(2) One -Period Nominal Wage Contract

\begin{tabular}{|c|c|c|c|c|c|c|}
\hline Var. & SD & Rank & \multicolumn{3}{|c|}{ Corr. With $y(t+j)$} & Auto \\
\cline { 4 - 6 } & $\%$ & SD & .1 & 0 & 1 & 1 \\
\hline inv. & 3.45 & 1 & 0.81 & 0.99 & 0.84 & 0.84 \\
\hline$y$ & 1.27 & 2 & 0.83 & 1.00 & 0.83 & 0.83 \\
\hline I & 0.77 & 3 & 0.92 & 0.87 & 0.63 & 0.68 \\
\hline w & 0.72 & 4 & 0.49 & 0.84 & 0.80 & 0.45 \\
\hline $\mathrm{c}$ & 0.41 & $\mathrm{~S}$ & 0.79 & 0.89 & 0.68 & 0.83 \\
\hline
\end{tabular}

(4) Monopolistic Competition without Price Adjustment Costs ( $\phi_{p}=0$ )

\begin{tabular}{|c|c|c|c|c|c|c|}
\hline Var. & SD & Rank & \multicolumn{3}{|c|}{ Corr. With y(i+j) } & Auto \\
\cline { 4 - 7 } & $\%$ & SD & -1 & 0 & 1 & 1 \\
\hline inv. & 3.79 & 1 & 0.67 & 0.99 & 0.74 & 0.71 \\
\hline y & 1.50 & 2 & 0.72 & 1.00 & 0.72 & 0.72 \\
\hline I & 0.59 & 4 & 0.60 & 0.96 & 0.74 & 0.71 \\
\hline w & 0.70 & 3 & 0.77 & 0.97 & 0.65 & 0.76 \\
\hline c & 0.58 & S & 0.78 & 0.93 & 0.60 & 0.79 \\
\hline
\end{tabular}

(6) Monopolistic Competition with Price Adjustment Costs ( $\phi_{\mathrm{p}}=5$ )

\begin{tabular}{|c|c|c|c|c|c|c|}
\hline Var. & SD & Rank & \multicolumn{3}{|c|}{ Corr. With y(1+j) } & Auto \\
\cline { 4 - 6 } & $\%$ & SD & -1 & 0 & 1 & 1 \\
\hline Inv. & 2.78 & 1 & 0.94 & 0.99 & 0.88 & 0.92 \\
\hline y & 1.12 & 2 & 0.90 & 1.00 & 0.90 & 0.90 \\
\hline I & 0.79 & 3 & 0.72 & 0.37 & 0.12 & 0.52 \\
\hline w & 0.52 & 4 & 0.92 & 0.96 & 0.83 & 0.91 \\
\hline c & 0.48 & 5 & 0.71 & 0.91 & 0.85 & 0.75 \\
\hline
\end{tabular}

(8) Monopolistic Competition $\left(\phi_{p}=5\right.$ ) with One-Period Nominal Wage Contract

\begin{tabular}{|c|c|c|c|c|c|c|}
\hline Var. & SD & Rank & \multicolumn{3}{|c|}{ Corr. With y(t+j) } & Auto \\
\cline { 4 - 6 } & $\%$ & SD & .1 & 0 & 1 & 1 \\
\hline inv. & 2.76 & 1 & 0.95 & 0.98 & 0.87 & $0.9 !$ \\
\hline$y$ & 1.09 & 2 & 0.92 & 1.00 & 0.92 & 0.92 \\
\hline I & 0.94 & 3 & 0.68 & 0.37 & 0.08 & 0.48 \\
\hline $\mathrm{w}$ & 0.52 & 4 & 0.79 & 0.91 & 0.87 & 0.77 \\
\hline $\mathrm{c}$ & 0.46 & 5 & 0.68 & 0.87 & 0.88 & 0.74 \\
\hline
\end{tabular}


Table 3. Changes in Population Moments - Nominal Wage Contract Models

(Compared to the same model with Constant Money Growth Rate Policy except for (1))

(1) Constant Money Growth Rate Rule $\left(\alpha_{\star}=1\right)$,

compared to the RBC model with Constant $M$ growth rate rule

A. One-Period Nominal Wage Contract

\begin{tabular}{|c|c|c|c|c|c|c|c|}
\hline Var. & SD & Rank & Diff & \multicolumn{3}{|c|}{ Corr. With y $(t+j)$} & Auto \\
\cline { 4 - 7 } & $\%$ & SD & SD & -1 & \multicolumn{1}{c|}{0} & 1 & 1 \\
\hline Inv. & 3.45 & 1 & -0.35 & 0.14 & 0.00 & 0.11 & 0.13 \\
\hline Y & 1.27 & 2 & -0.12 & 0.12 & 0.00 & 0.12 & 0.12 \\
\hline L & 0.77 & 3 & -0.05 & 0.28 & -0.11 & -0.11 & -0.02 \\
\hline W & 0.72 & 4 & 0.11 & -0.29 & -0.12 & 0.17 & -0.32 \\
\hline C & 0.41 & 5 & -0.02 & 0.01 & 0.01 & 0.14 & 0.01 \\
\hline
\end{tabular}

(2) Counter-Cyclical Policy $\left(\alpha_{b}=1, \alpha_{y y}=-1\right)$

A. One-Period Nominal Wage Contract

\begin{tabular}{|c|c|c|c|c|c|c|c|}
\hline \multirow[t]{2}{*}{ Var. } & \multirow{2}{*}{$\begin{array}{l}\text { SD } \\
\%\end{array}$} & \multirow{2}{*}{$\begin{array}{c}\text { Rank } \\
\text { SD }\end{array}$} & \multirow{2}{*}{$\begin{array}{l}\text { Diff } \\
\text { SD }\end{array}$} & \multicolumn{3}{|c|}{ Corr. With y $(t+i)$} & \multirow{2}{*}{$\begin{array}{c}\text { Auto } \\
1\end{array}$} \\
\hline & & & & -1 & 0 & 1 & \\
\hline Inv. & 3.44 & 1 & -0.01 & 0.01 & 0.00 & -0.02 & -0.02 \\
\hline $\mathrm{Y}$ & 1.25 & 2 & -0.02 & 0.01 & 0.00 & 0.01 & 0.01 \\
\hline $\mathrm{L}$ & 1.03 & 3 & 0.26 & .0 .14 & -0.13 & -0.29 & -0.38 \\
\hline W & 0.84 & 4 & 0.13 & -0.20 & -0.27 & 0.03 & -0.19 \\
\hline C & 0.39 & 5 & -0.02 & -0.02 & -0.03 & 0.08 & 0.01 \\
\hline
\end{tabular}

(3) Pro-Cyclical Policy $\left(\alpha_{h}=1, \alpha_{y y}=1\right)$

\section{A. One-Period Nominal Wage Contract}

\begin{tabular}{|c|c|c|c|c|c|c|c|}
\hline Var. & SD & Rank & Diff & \multicolumn{3}{|c|}{ Corr. With y(t+j) } & Auto \\
\cline { 4 - 7 } & $\%$ & SD & SD & -1 & \multicolumn{1}{|c|}{0} & 1 & I \\
\hline Inv. & 4.94 & 1 & 1.49 & -0.42 & 0.00 & -0.36 & -0.42 \\
\hline Y & 1.72 & 2 & 0.45 & -0.36 & 0.00 & -0.36 & -0.36 \\
\hline L & 1.58 & 3 & 0.81 & -0.79 & 0.05 & -0.20 & -0.50 \\
\hline W & 0.67 & 4 & -0.04 & 0.41 & -0.44 & -0.60 & 0.30 \\
\hline C & 0.48 & 5 & 0.07 & -0.09 & -0.09 & -0.36 & -0.02 \\
\hline
\end{tabular}

(4) Counter-Inflation Policy ( $\alpha_{h}=1, \alpha_{\pi}=-0.9$ )

A. One-Period Nominal Wage Contract

\begin{tabular}{|c|c|c|c|c|c|c|c|}
\hline Var. & SD & Rank & Diff & \multicolumn{2}{|c|}{ Corr. With $y(t+j)$} & Auto \\
\cline { 5 - 8 } & $\%$ & SD & SD & -1 & 0 & 1 & 1 \\
\hline Inv. & 3.68 & 1 & 0.23 & -0.09 & 0.00 & -0.07 & -0.08 \\
\hline$y$ & 1.35 & 2 & 0.08 & -0.08 & 0.00 & -0.08 & -0.08 \\
\hline I & 0.76 & 3 & -0.01 & -0.16 & 0.11 & 0.14 & 0.12 \\
\hline w & 0.63 & 4 & -0.09 & 0.22 & 0.13 & -0.11 & 0.24 \\
\hline c & 0.43 & 5 & 0.02 & -0.01 & 0.00 & -0.10 & -0.01 \\
\hline
\end{tabular}

B. Multi -Period Nominal Wage Contract

\begin{tabular}{|c|c|c|c|c|c|c|c|}
\hline \multirow[t]{2}{*}{ Var. } & \multirow{2}{*}{$\begin{array}{l}\text { SD } \\
\%\end{array}$} & \multirow{2}{*}{$\begin{array}{c}\text { Rank } \\
\text { SD }\end{array}$} & \multirow{2}{*}{$\begin{array}{l}\text { Diff } \\
\text { SD }\end{array}$} & \multicolumn{3}{|c|}{ Corr. With $y(t+i)$} & \multirow{2}{*}{$\begin{array}{c}\text { Auto } \\
1\end{array}$} \\
\hline & & & & -1 & 0 & 1 & \\
\hline inv. & 3.08 & 1 & -0.73 & 0.08 & 0.00 & 0.06 & 0.07 \\
\hline$y$ & 1.16 & 2 & -0.23 & 0.06 & 0.00 & 0.06 & .06 \\
\hline 1 & 0.00 & 3 & -0.23 & 0.14 & -0.18 & -0.14 & $0.1 !$ \\
\hline w & 0.50 & 7 & -0.10 & 0.07 & -0.02 & 0.03 & 0.08 \\
\hline 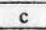 & 0.39 & 5 & -0.05 & 0.01 & 0.03 & 0.10 & 0.00 \\
\hline
\end{tabular}

B. Multi-Period Nominal Wage Contract

\begin{tabular}{|c|c|c|c|c|c|c|c|}
\hline \multirow[t]{2}{*}{ Var. } & \multirow{2}{*}{$\begin{array}{l}\text { SD } \\
\%\end{array}$} & \multirow{2}{*}{$\begin{array}{c}\text { Rank } \\
\text { SD }\end{array}$} & \multirow{2}{*}{$\begin{array}{l}\text { Diff } \\
\text { SD }\end{array}$} & \multicolumn{3}{|c|}{ Corr. With $y(t+j)$} & \multirow{2}{*}{$\begin{array}{c}\text { Auto } \\
1\end{array}$} \\
\hline & & & & -1 & 0 & 1 & \\
\hline Inv. & 2.85 & 1 & -0.22 & 0.11 & 0.00 & 0.08 & 0.10 \\
\hline$y$ & 1.07 & 2 & -0.09 & 0.09 & 0.00 & 0.09 & 0.09 \\
\hline 1 & $0.8 !$ & 3 & 0.21 & 0.02 & -0.23 & -0.21 & -0.08 \\
\hline$w$ & 0.48 & 4 & -0.03 & 0.09 & 0.02 & 0.05 & 0.07 \\
\hline c & 0.36 & 5 & -0.03 & -0.01 & -0.01 & 0.09 & 0.00 \\
\hline
\end{tabular}

B. Multi-Period Nominal Wage Contract

\begin{tabular}{|c|c|c|c|c|c|c|c|}
\hline Var. & SD & Rank & Diff & \multicolumn{3}{|c|}{ Corr. With $y(t+j)$} & Auto \\
\cline { 5 - 7 } & $\%$ & SD & SD & -1 & 0 & 1 & I \\
\hline inv. & 4.47 & 1 & 1.40 & -0.26 & 0.00 & -0.23 & -0.26 \\
\hline y & 1.59 & 2 & 0.43 & -0.22 & 0.00 & -0.22 & -0.22 \\
\hline I & 1.27 & 3 & 0.67 & -0.52 & 0.13 & -0.07 & -0.51 \\
\hline w & 0.70 & 4 & 0.19 & -0.24 & 0.04 & -0.17 & -0.25 \\
\hline c & 0.46 & 5 & 0.07 & -0.06 & -0.08 & -0.24 & -0.01 \\
\hline
\end{tabular}

B. Multi -Period Nominal Wage Contract

\begin{tabular}{|c|c|c|c|c|c|c|c|}
\hline \multirow[t]{2}{*}{ Var. } & \multirow{2}{*}{$\begin{array}{l}\text { SD } \\
\%\end{array}$} & \multirow{2}{*}{$\begin{array}{c}\text { Rank } \\
\text { SD }\end{array}$} & \multirow{2}{*}{$\begin{array}{l}\text { Diff } \\
\text { SD }\end{array}$} & \multicolumn{3}{|c|}{ Corr. With $y(t+j)$} & \multirow{2}{*}{$\begin{array}{c}\text { Auto } \\
1\end{array}$} \\
\hline & & & & -1 & 0 & 1 & \\
\hline inv. & 3.43 & 1 & 0.35 & -0.10 & 0.00 & -0.09 & -0.10 \\
\hline$y$ & 1.27 & 2 & 0.11 & -0.08 & 0.00 & -0.08 & -0.08 \\
\hline 1 & 0.66 & 3 & 0.06 & -0.22 & 0.15 & 0.06 & -0.26 \\
\hline$w$ & 0.55 & 4 & 0.05 & .0 .09 & 0.01 & -0.06 & -0.09 \\
\hline c & 0.41 & 5 & 0.02 & -0.01 & -0.02 & -0.09 & 0.00 \\
\hline
\end{tabular}


Table 4. Changes in Population Moments - Monopolistic Comp. Model with Price Adjustment Costs

( Compared to the same model with Constant Money Growth Rate Policy except for (1))

(1) Constant Money Growtb Rate Rule $\left(\alpha_{b}=1\right)$,

compared to the MC model witb $\phi_{p}=0$ and Constant Money Growth Rate Policy Rule

A. $\phi_{p}=1$

\begin{tabular}{|c|c|c|c|c|c|c|c|}
\hline Var. & SD & Rank & Diff & \multicolumn{3}{|c|}{ Corr. With y $(\iota+j)$} & Auto \\
\cline { 5 - 7 } & $\%$ & SD & SD & -1 & 0 & 1 & 1 \\
\hline inv. & 3.56 & 1 & -0.24 & 0.10 & 0.00 & 0.07 & 0.09 \\
\hline y & 1.42 & 2 & -0.08 & 0.07 & 0.00 & 0.07 & 0.07 \\
\hline I & 0.52 & $5^{\bullet}$ & -0.08 & 0.28 & -0.04 & 0.00 & 0.15 \\
\hline w & 0.67 & 3 & -0.03 & 0.06 & 0.00 & 0.06 & 0.06 \\
\hline c & 0.56 & $4^{*}$ & -0.02 & 0.01 & 0.01 & 0.08 & 0.00 \\
\hline
\end{tabular}

(2) Counter-Cyclical Policy $\left(\alpha_{h}=1, \alpha_{y y}=-1\right)$

A. $\phi_{\mathrm{p}}=$ I

\begin{tabular}{|c|c|c|c|c|c|c|c|}
\hline \multirow[t]{2}{*}{ Var. } & \multirow{2}{*}{$\begin{array}{l}\text { SD } \\
\%\end{array}$} & \multirow{2}{*}{$\begin{array}{c}\text { Rank } \\
\text { SD }\end{array}$} & \multirow{2}{*}{$\begin{array}{l}\text { Diff } \\
\text { SD }\end{array}$} & \multicolumn{3}{|c|}{ Corr. With $y(t+j)$} & \multirow{2}{*}{$\begin{array}{c}\text { Auto } \\
1\end{array}$} \\
\hline & & & & -1 & 0 & 1 & \\
\hline inv. & 3.33 & I & -0.22 & 0.07 & 0.00 & 0.04 & 0.06 \\
\hline$y$ & 1.34 & 2 & -0.08 & 0.05 & 0.00 & 0.05 & 0.05 \\
\hline 1 & 0.54 & $4^{\circ}$ & 0.02 & 0.07 & -0.17 & -0.18 & -0.14 \\
\hline w & 0.63 & 3 & -0.04 & 0.04 & 0.00 & 0.04 & 0.04 \\
\hline c & 0.54 & 4 & -0.02 & -0.01 & 0.00 & 0.07 & 0.00 \\
\hline
\end{tabular}

(3) Pro-Cyclical Policy $\left(\alpha_{b}=1, \alpha_{y y}=1\right)$

$$
\text { A. } \phi_{\mathrm{p}}=1
$$

\begin{tabular}{|c|c|c|c|c|c|c|c|}
\hline Var. & SD & Rank & Diff & \multicolumn{2}{|c|}{ Corr. With $y(t+\mathrm{j})$} & Auto \\
\cline { 5 - 8 } & $\%$ & SD & SD & -1 & 0 & 1 & 1 \\
\hline inv. & 3.79 & 1 & 0.24 & -0.10 & 0.00 & -0.07 & -0.09 \\
\hline$y$ & 1.50 & 2 & 0.08 & -0.07 & 0.00 & -0.07 & -0.07 \\
\hline 1 & 0.59 & $4^{*}$ & 0.08 & -0.29 & 0.04 & 0.00 & -0.16 \\
\hline w & 0.70 & 3 & 0.03 & -0.06 & 0.00 & -0.06 & -0.06 \\
\hline c & 0.58 & $5^{*}$ & 0.02 & -0.01 & -0.01 & -0.08 & 0.00 \\
\hline
\end{tabular}

(4) Counter-Inflation Policy $\left(\alpha_{n}=1, \alpha_{1}=-0.9\right)$

$$
\text { 4. } \phi_{0}=1
$$

\begin{tabular}{|c|c|c|c|c|c|c|c|}
\hline Var. & SD & Rank & Diff & \multicolumn{2}{|c|}{ Cor. With y $(t+\mathrm{j})$} & Auto \\
\cline { 5 - 8 } & $\%$ & SD & SD & -1 & 0 & I & 1 \\
\hline inv. & 3.67 & $I$ & 0.11 & -0.04 & 0.00 & -0.03 & -0.04 \\
\hline$y$ & 1.46 & 2 & 0.04 & -0.03 & 0.00 & -0.03 & -0.03 \\
\hline 1 & 0.54 & 5 & 0.02 & -0.11 & 0.04 & 0.03 & -0.03 \\
\hline w & 0.68 & 3 & 0.02 & -0.03 & 0.00 & -0.03 & -0.03 \\
\hline $\mathrm{c}$ & 0.57 & 4 & 0.01 & 0.00 & 0.00 & -0.04 & 0.00 \\
\hline
\end{tabular}

\begin{tabular}{|c|c|c|c|c|c|c|c|}
\hline \multirow[t]{2}{*}{ Var. } & \multirow{2}{*}{$\begin{array}{l}\text { SD } \\
\%\end{array}$} & \multirow{2}{*}{$\begin{array}{c}\text { Rank } \\
\text { SD }\end{array}$} & \multirow{2}{*}{$\begin{array}{l}\text { Diff } \\
\text { SD }\end{array}$} & \multicolumn{3}{|c|}{ Corr. With $y(t+j)$} & \multirow{2}{*}{$\begin{array}{c}\text { Auto } \\
1\end{array}$} \\
\hline & & & & .1 & 0 & 1 & \\
\hline inv. & 2.78 & 1 & -1.01 & 0.26 & -0.01 & 0.14 & 0.21 \\
\hline$y$ & 1.12 & 2 & -0.38 & 0.19 & 0.00 & 0.19 & 0.19 \\
\hline 1 & 0.79 & $3^{\circ}$ & 0.19 & 0.12 & .0 .59 & .0 .62 & -0.19 \\
\hline$w$ & 0.52 & $4^{\circ}$ & -0.18 & 0.15 & -0.01 & 0.17 & 0.15 \\
\hline c & 0.48 & $5^{*}$ & -0.10 & .0 .07 & .0 .02 & 0.25 & -0.04 \\
\hline
\end{tabular}

$$
\text { B. } \phi_{p}=5
$$

\begin{tabular}{|c|c|c|c|c|c|c|c|}
\hline \multirow[t]{2}{*}{ Var. } & \multirow{2}{*}{$\begin{array}{l}\mathrm{SD} \\
\%\end{array}$} & \multirow{2}{*}{$\begin{array}{c}\text { Rank } \\
\text { SD }\end{array}$} & \multirow{2}{*}{$\begin{array}{l}\text { Diff } \\
\text { SD }\end{array}$} & \multicolumn{3}{|c|}{ Corr. With $y(t+j)$} & \multirow{2}{*}{$\begin{array}{c}\text { Auto } \\
1\end{array}$} \\
\hline & & & & -1 & 0 & 1 & \\
\hline inv. & 2.16 & 1 & -0.62 & 0.05 & .0 .03 & .0 .04 & 0.01 \\
\hline$y$ & 0.85 & $3^{\circ}$ & -0.28 & 0.03 & 0.00 & 0.03 & 0.03 \\
\hline 1 & 1.07 & $2^{\circ}$ & 0.28 & -0.22 & -0.02 & -0.02 & 0.06 \\
\hline$w$ & 0.39 & $5^{*}$ & .0 .14 & 0.01 & 0.00 & 0.04 & 0.02 \\
\hline c & 0.43 & $4^{\circ}$ & -0.05 & .0 .18 & -0.13 & -0.01 & -0.07 \\
\hline
\end{tabular}

$$
\text { B. } \phi_{p}=5
$$

$$
\text { B. } \phi_{\mathrm{p}}=5
$$

\begin{tabular}{|c|c|c|c|c|c|r|r|}
\hline Var. & SD & Rank & Diff & \multicolumn{3}{|c|}{ Corr. With $y(t+j)$} & Auto \\
\cline { 5 - 8 } & $\%$ & SD & SD & -1 & 0 & 1 & \multicolumn{1}{c|}{1} \\
\hline inv. & 3.79 & 1 & 1.01 & -0.26 & 0.01 & -0.14 & -0.21 \\
\hline y & 1.50 & 2 & 0.38 & -0.19 & 0.00 & -0.19 & -0.19 \\
\hline I & 0.60 & $4^{\bullet}$ & -0.19 & -0.12 & 0.59 & 0.62 & 0.18 \\
\hline w & 0.70 & $3^{\circ}$ & 0.18 & -0.15 & 0.01 & -0.17 & -0.15 \\
\hline c & 0.58 & 5 & 0.10 & 0.07 & 0.02 & -0.25 & 0.04 \\
\hline
\end{tabular}

$$
\text { B. } \phi_{Q}=5
$$

\begin{tabular}{|c|c|c|c|c|c|c|c|}
\hline Var. & SD & Rank & Diff & \multicolumn{2}{|c|}{ Corr. With $y(t+\mathrm{i})$} & Auto \\
\cline { 5 - 8 } & $\%$ & SD & SD & \multicolumn{1}{c|}{-1} & 0 & 1 & 1 \\
\hline inv. & 3.20 & 1 & 0.41 & -0.07 & 0.01 & -0.02 & -0.04 \\
\hline$y$ & 1.29 & 2 & 0.17 & -0.04 & 0.00 & -0.04 & -0.04 \\
\hline I & 0.58 & $4^{\circ}$ & -0.20 & 0.20 & 0.28 & 0.31 & 0.11 \\
\hline w & 0.61 & $3^{\circ}$ & 0.08 & -0.03 & 0.00 & -0.04 & -0.04 \\
\hline c & 0.52 & 6 & 0.05 & 0.06 & 0.03 & -0.07 & 0.03 \\
\hline
\end{tabular}


Table 4 (Continue). Changes in Population Moments

(1) Constant Money Growth Rate Rule $\left(\alpha_{h}=1\right)$

compared to the MC model with $\phi_{p}=0$ and Constant Money Growth Rate Rule

C. $\phi_{\mathrm{p}}=15$

\begin{tabular}{|c|c|c|r|r|r|r|r|}
\hline Var & SD & Rank & Diff & \multicolumn{2}{|c|}{ Corr. With y } & $(+\mathrm{j})$ & Auto \\
\cline { 5 - 8 } & $\%$ & SD & \multicolumn{1}{c|}{ SD } & \multicolumn{1}{c|}{-1} & \multicolumn{1}{c|}{0} & \multicolumn{1}{c|}{ I } & I \\
\hline inv. & 1.80 & 1 & -2.00 & 0.31 & -0.09 & 0.03 & 0.20 \\
\hline y & 0.67 & 3 & -0.83 & 0.23 & 0.00 & 0.23 & 0.23 \\
\hline I & 1.22 & 2 & 0.62 & -0.20 & -0.87 & -0.89 & -0.08 \\
\hline w & 0.30 & 5 & -0.40 & 0.14 & -0.02 & 0.24 & 0.16 \\
\hline c & 0.41 & 4 & -0.17 & -0.43 & -0.31 & 0.15 & -0.15 \\
\hline
\end{tabular}

(2) Counter-Cyclical Policy $\left(\alpha_{h}=1, \alpha_{y y}=-1\right)$

$$
\text { C. } \phi_{\mathrm{p}}=15
$$

\begin{tabular}{|c|c|c|c|c|c|c|c|}
\hline \multirow[t]{2}{*}{ Var. } & \multirow{2}{*}{$\begin{array}{l}\text { SD } \\
\%\end{array}$} & \multirow{2}{*}{$\begin{array}{c}\text { Rank } \\
\text { SD }\end{array}$} & \multirow{2}{*}{$\begin{array}{l}\text { Diff } \\
\text { SD }\end{array}$} & \multicolumn{3}{|c|}{ Corr. With $y(t+j)$} & \multirow{2}{*}{$\begin{array}{c}\text { Auto } \\
1\end{array}$} \\
\hline & & & & -1 & 0 & 1 & \\
\hline inv. & 1.36 & 2 & -0.44 & -0.11 & -0.20 & -0.25 & -0.08 \\
\hline$y$ & 0.39 & $4^{*}$ & -0.28 & 0.01 & 0.00 & 0.01 & $0.0 !$ \\
\hline 1 & 1.39 & $1^{*}$ & 0.18 & -0.10 & .0 .08 & -0.07 & 0.05 \\
\hline W & 0.17 & 5 & -0.13 & -0.15 & -0.07 & 0.01 & -0.08 \\
\hline C & 0.43 & 3 & 0.02 & -0.30 & -0.28 & -0.22 & -0.01 \\
\hline
\end{tabular}

(3) Pro-Cyclical Policy $\left(\alpha_{h}=1, \alpha_{y y}=1\right)$

C. $\phi_{\mathrm{p}}=15$

\begin{tabular}{|c|c|c|r|r|r|r|r|}
\hline Var. & SD & Rank & Diff & \multicolumn{3}{|c|}{ Cotr. With $y(t+j)$} & Auto \\
\cline { 5 - 8 } & $\%$ & SD & SD & \multicolumn{1}{c|}{-1} & \multicolumn{1}{c|}{0} & \multicolumn{1}{c|}{ I } & \multicolumn{1}{c}{ I } \\
\hline Inv. & 3.80 & I & 2.00 & -0.32 & 0.09 & -0.04 & -0.20 \\
\hline Y & 1.50 & $2^{*}$ & 0.83 & -0.23 & 0.00 & -0.23 & -0.23 \\
\hline L & 0.60 & $4^{*}$ & -0.62 & 0.18 & 0.87 & 0.89 & 0.07 \\
\hline W & 0.70 & $3^{*}$ & 0.40 & -0.14 & 0.02 & -0.24 & -0.17 \\
\hline C & 0.58 & $5^{*}$ & 0.17 & 0.42 & 0.31 & -0.15 & 0.15 \\
\hline
\end{tabular}

(4) Counter-Inflation Policy $\left(\alpha_{h}=1, \alpha_{n}=-0.9\right)$

$$
\text { C. } \phi_{p}=15
$$

\begin{tabular}{|c|c|c|c|c|c|c|c|}
\hline \multirow[t]{2}{*}{ Var. } & \multirow{2}{*}{$\begin{array}{l}\text { SD } \\
\%\end{array}$} & \multirow{2}{*}{$\begin{array}{l}\text { Rank } \\
\text { SD }\end{array}$} & \multirow{2}{*}{$\begin{array}{l}\text { Diff } \\
\text { SD }\end{array}$} & \multicolumn{3}{|c|}{ Corr. With y $(t+j)$} & \multirow{2}{*}{ Auto } \\
\hline & & & & -1 & 0 & 1 & \\
\hline inv. & 2.37 & 1 & 0.57 & -0.01 & 0.07 & 0.09 & 0.03 \\
\hline $\mathrm{Y}$ & 0.95 & 3 & 0.28 & -0.02 & 0.00 & -0.02 & -0.02 \\
\hline $\mathrm{L}$ & 0.96 & 2 & .0 .26 & 0.15 & 0.12 & 0.12 & -0.07 \\
\hline W & 0.44 & $4 *$ & 0.14 & 0.02 & 0.01 & .0 .04 & 0.00 \\
\hline $\mathrm{C}$ & 0.44 & 4 & 0.03 & 0.26 & 0.22 & 0.11 & 0.07 \\
\hline
\end{tabular}

D. 1 period-NWC1 - MC with $\phi_{p}=5$

\begin{tabular}{|c|c|c|c|c|c|c|c|}
\hline Var. & SD & Rank & Diff & \multicolumn{2}{|c|}{ Corr. With y } & $t+j)$ & Autt \\
\cline { 5 - 7 } & $\%$ & SD & SD & \multicolumn{1}{c|}{-1} & \multicolumn{1}{c|}{0} & 1 & 1 \\
\hline inv. & 2.76 & 1 & -1.03 & 0.28 & -0.01 & 0.13 & 0.20 \\
\hline$y$ & 1.09 & 2 & -0.41 & 0.20 & 0.00 & 0.20 & 0.20 \\
\hline I & 0.94 & $3^{*}$ & 0.34 & 0.07 & -0.59 & -0.67 & -0.22 \\
\hline w & 0.52 & $4^{*}$ & -0.19 & 0.02 & -0.06 & 0.22 & 0.01 \\
\hline$c$ & 0.46 & 5 & -0.11 & -0.11 & -0.07 & 0.28 & -0.05 \\
\hline
\end{tabular}

\begin{tabular}{|c|c|c|c|c|c|c|c|}
\hline \multirow[t]{2}{*}{ Var. } & \multirow{2}{*}{$\begin{array}{l}\text { SD } \\
\%\end{array}$} & \multirow{2}{*}{$\begin{array}{c}\text { Rank } \\
\text { SD }\end{array}$} & \multirow{2}{*}{$\begin{array}{l}\text { Diff } \\
\text { SD }\end{array}$} & \multicolumn{3}{|c|}{ Con. With $y(t+j)$} & \multirow{2}{*}{$\begin{array}{c}\text { Aut } \\
1\end{array}$} \\
\hline & & & & -1 & 0 & 1 & \\
\hline inv. & 2.22 & 1 & -0.55 & 0.03 & -0.03 & -0.05 & -0.02 \\
\hline$y$ & 0.82 & 3 & -0.27 & 0.02 & 0.00 & 0.02 & 0.02 \\
\hline 1 & 1.22 & 2 & 0.28 & -0.15 & -0.12 & -0.12 & 0.09 \\
\hline$w$ & 0.40 & 5 & -0.12 & -0.13 & -0.15 & -0.07 & -0.22 \\
\hline $\mathrm{c}$ & 0.41 & 4 & -0.05 & -0.23 & -0.19 & -0.06 & -0.08 \\
\hline
\end{tabular}

D. 1 period-NWC1 - MC with $\phi_{p}=5$

D. 1 period-NWC1 - MC with $\phi_{\mathrm{P}}=5$

\begin{tabular}{|c|c|c|c|r|r|r|r|}
\hline Var. & SD & Rank & Diff & \multicolumn{2}{|c|}{ Corr. With y $[t+j)$} & Aut $(t)$ \\
\cline { 5 - 7 } & $\%$ & SD & SD & -1 & \multicolumn{1}{c|}{0} & I & 1 \\
\hline inv. & 5.51 & 1 & 2.75 & -0.64 & 0.01 & -0.46 & -0.58 \\
\hline$y$ & 2.00 & 2 & 0.91 & -0.51 & -0.51 & 0.00 & -0.51 \\
\hline I & 1.58 & 3 & 0.64 & -0.68 & 0.52 & 0.27 & -0.40 \\
\hline w & 0.78 & 4 & 0.27 & 0.09 & -0.56 & -0.70 & -0.02 \\
\hline c & 0.64 & 5 & 0.18 & 0.02 & -0.04 & -0.57 & 0.04 \\
\hline
\end{tabular}

\begin{tabular}{|c|c|c|c|c|c|c|c|}
\hline \multirow[t]{2}{*}{ Var. } & \multirow{2}{*}{$\begin{array}{c}\text { SD } \\
\%\end{array}$} & \multirow{2}{*}{$\begin{array}{c}\text { Rank } \\
\text { SD }\end{array}$} & \multirow{2}{*}{$\begin{array}{l}\text { Diff } \\
\text { SD }\end{array}$} & \multicolumn{3}{|c|}{ Corr. With y[t+j) } & \multirow{2}{*}{$\begin{array}{c}\text { Aut: } \\
1\end{array}$} \\
\hline & & & & -1 & 0 & I & \\
\hline inv. & 3.17 & 1 & 0.41 & -0.07 & 0.01 & 0.00 & -0.3 \\
\hline$y$ & 1.28 & 2 & 0.19 & -0.05 & 0.00 & -0.05 & -0.5 \\
\hline 1 & 0.61 & 3 & .0 .33 & 0.22 & 0.24 & 0.31 & 0.10 \\
\hline$w$ & 0.60 & 4 & 0.09 & 0.07 & 0.06 & -0.07 & 0.18 \\
\hline c & 0.52 & 5 & 0.06 & 0.09 & 0.07 & -0.08 & 0.014 \\
\hline
\end{tabular}

D. 1 period-NWC1 - MC with $\phi_{p}-5$ 
Table 5. Benchmark Case: AR-1 Money Growth Rate Rulewith Monetary Disturbances $\left(\alpha_{n}=1\right.$, $\alpha_{b 1}=1, \sigma_{h}=.0075, \sigma_{h}=.0070$ )

(1) Real Business Cycle Model

\begin{tabular}{|c|c|c|c|c|c|c|}
\hline Var. & SD & Rank & \multicolumn{3}{|c|}{ Corr. With $y(1+j)$} & Auto \\
\cline { 4 - 6 } & $\%$ & $S D$ & -1 & 0 & 1 & 1 \\
\hline inv. & 3.80 & 1 & 0.67 & 0.99 & 0.74 & 0.71 \\
\hline$y$ & 1.39 & 2 & 0.72 & 1.00 & 0.72 & 0.72 \\
\hline I & 0.83 & 3 & 0.64 & 0.98 & 0.74 & 0.71 \\
\hline w & 0.61 & 4 & 0.78 & 0.96 & 0.64 & 0.77 \\
\hline c & 0.43 & 5 & 0.78 & 0.87 & 0.54 & 0.82 \\
\hline
\end{tabular}

(3) Multi-Period Nominal Wage Contract

\begin{tabular}{|c|c|c|c|c|c|c|}
\hline Var. & SD & Rank & \multicolumn{2}{|c|}{ Corr. With y $[\mathrm{t}+\mathrm{j})$} & Auto \\
\cline { 4 - 7 } & $\%$ & SD & -1 & 0 & 1 & 1 \\
\hline inv. & 3.32 & 1 & 0.70 & 0.99 & 0.74 & 0.72 \\
\hline$y$ & 1.22 & 2 & 0.74 & 1.00 & 0.74 & 0.74 \\
\hline I & 0.90 & 3 & 0.57 & 0.74 & 0.47 & 0.56 \\
\hline w & 0.54 & 4 & 0.79 & 0.94 & 0.63 & 0.79 \\
\hline c & 0.39 & 5 & 0.77 & 0.87 & 0.60 & 0.82 \\
\hline
\end{tabular}

(5) Monopolistic Competition with

Price Adjustment Costs $\left(\phi_{p}=1\right)$

\begin{tabular}{|c|c|c|c|c|c|c|}
\hline Var. & SD & Rank & \multicolumn{3}{|c|}{ Corr. With $y(t+j)$} & Auto \\
\cline { 4 - 6 } & $\%$ & SD & -1 & 0 & 1 & 1 \\
\hline inv. & 3.62 & 1 & 0.76 & 0.99 & 0.80 & 0.79 \\
\hline y & 1.44 & 2 & 0.78 & 1.00 & 0.78 & 0.78 \\
\hline I & 0.60 & 4 & 0.79 & 0.86 & 0.67 & 0.75 \\
\hline w & 0.67 & 3 & 0.83 & 0.97 & 0.71 & 0.81 \\
\hline c & 0.56 & S & 0.78 & 0.93 & 0.68 & 0.79 \\
\hline
\end{tabular}

(7) Monopolistic Competition with

Price Adjustment Costs ( $\left.\phi_{p}=15\right)$

\begin{tabular}{|c|c|c|c|c|c|c|}
\hline Var. & SD & Rank & \multicolumn{2}{|c|}{ Corr. With y $(t+j)$} & Auto \\
\cline { 4 - 6 } & $\%$ & SD & -1 & 0 & 1 & 1 \\
\hline inv. & 4.36 & 1 & 0.80 & 0.97 & 0.83 & 0.83 \\
\hline y & 1.37 & 3 & 0.85 & 1.00 & 0.85 & 0.85 \\
\hline I & 2.10 & 2 & 0.66 & 0.73 & 0.56 & 0.75 \\
\hline w & 0.58 & 4 & 0.90 & 0.93 & 0.72 & 0.89 \\
\hline c & 0.49 & 5 & 0.35 & 0.32 & 0.25 & 0.72 \\
\hline
\end{tabular}

(2) One-Period Nominal Wage Contract

\begin{tabular}{|c|c|c|c|c|c|c|}
\hline Var. & SD & Rank & \multicolumn{3}{|c|}{ Corr. With y $(1+j)$} & Auto \\
\cline { 4 - 6 } & $\%$ & SD & -1 & 0 & 1 & I \\
\hline inv. & 3.76 & 1 & 0.69 & 0.99 & 0.72 & 0.69 \\
\hline$y$ & 1.35 & 2 & 0.73 & 1.00 & 0.73 & 0.73 \\
\hline 1 & 1.11 & 3 & 0.58 & 0.81 & 0.40 & 0.29 \\
\hline w & 0.79 & 4 & 0.43 & 0.57 & 0.69 & 0.35 \\
\hline$c$ & 0.41 & 5 & 0.75 & 0.84 & 0.63 & 0.83 \\
\hline
\end{tabular}

(4) Monopolistic Competition without Price Adjustment Costs $\left(\phi_{p}=0\right.$ )

\begin{tabular}{|c|c|c|c|c|c|c|}
\hline Var. & SD & Rank & \multicolumn{3}{|c|}{ Cor. With $y(t+j)$} & Auto \\
\cline { 4 - 6 } & $\%$ & SD & -1 & 0 & 1 & 1 \\
\hline inv. & 3.79 & 1 & 0.67 & 0.99 & 0.74 & 0.71 \\
\hline$y$ & 1.50 & 2 & 0.72 & 1.00 & 0.72 & 0.72 \\
\hline 1 & 0.59 & 4 & 0.60 & 0.96 & 0.74 & 0.71 \\
\hline w & 0.70 & 3 & 0.77 & 0.97 & 0.65 & 0.76 \\
\hline$c$ & 0.58 & 5 & 0.78 & 0.93 & 0.60 & 0.79 \\
\hline
\end{tabular}

(6) Monopolistic Competition with Price Adjustment Costs $\left(\phi_{p}=5\right)$

\begin{tabular}{|c|c|c|c|c|c|c|}
\hline \multirow[t]{2}{*}{ Var. } & \multirow{2}{*}{$\begin{array}{l}\text { SD } \\
\%\end{array}$} & \multirow{2}{*}{$\begin{array}{c}\text { Rank } \\
\text { SD }\end{array}$} & \multicolumn{3}{|c|}{ Cor. With $y(i+j)$} & \multirow{2}{*}{$\begin{array}{c}\text { Auto } \\
1\end{array}$} \\
\hline & & & -1 & 0 & 1 & \\
\hline inv. & 3.72 & 1 & 0.82 & 0.98 & 0.82 & 0.82 \\
\hline$y$ & 1.35 & 2 & 0.84 & 1.00 & 0.84 & 0.84 \\
\hline 1 & 1.34 & 3 & 0.64 & 0.62 & 0.39 & 0.64 \\
\hline$w$ & 0.61 & 4 & 0.88 & 0.96 & 0.76 & 0.87 \\
\hline c & 0.50 & 5 & 0.65 & 0.76 & 0.67 & 0.76 \\
\hline
\end{tabular}

(8) Monopolistic Competition ( $\phi_{D}=5$ ) with One-Period Nominal Wage Contract

\begin{tabular}{|c|c|c|c|c|c|c|}
\hline Var. & SD & Rank & \multicolumn{3}{|c|}{ Cor. With y $(i+j)$} & Auto \\
\cline { 4 - 6 } & $\%$ & SD & -1 & 0 & 1 & I \\
\hline inv. & 4.20 & 1 & 0.77 & 0.98 & 0.77 & 0.76 \\
\hline y & 1.45 & 3 & 0.80 & 1.00 & 0.80 & 0.80 \\
\hline I & 1.68 & 2 & 0.62 & 0.70 & 0.41 & 0.60 \\
\hline w & 0.64 & 4 & 0.85 & 0.75 & 0.59 & 0.70 \\
\hline c & 0.49 & 5 & 0.59 & 0.66 & 0.60 & 0.76 \\
\hline
\end{tabular}


Table 6. Changes in Population Moments-One-Period Nominal Wage Contract Model, compared to tbe AR-1 Rule with Monetary Disturbances

(1) AR-1 Rule $\left(\alpha_{h}=1, \alpha_{h t}=0.42, \sigma_{h}=.0075\right)$

compared to tbe RBC model under Constant Money

Growth Rate Rule witbout Monetary Disturbances

\begin{tabular}{|c|c|c|c|c|c|c|c|}
\hline \multirow[t]{2}{*}{ Var. } & \multirow{2}{*}{$\begin{array}{l}\text { SD } \\
\%\end{array}$} & \multirow{2}{*}{$\begin{array}{c}\text { Rank } \\
\text { SD }\end{array}$} & \multirow{2}{*}{$\begin{array}{l}\text { Diff } \\
\text { SD }\end{array}$} & \multicolumn{3}{|c|}{ Corr. With y $(t+j)$} & \multirow{2}{*}{$\begin{array}{c}\text { Auto } \\
\text { I }\end{array}$} \\
\hline & & & & -1 & 0 & 1 & \\
\hline inv. & 3.76 & 1 & -0.04 & 0.02 & 0.00 & -0.01 & .0 .01 \\
\hline$y$ & 1.35 & 2 & -0.04 & 0.01 & 0.00 & 0.01 & 0.01 \\
\hline 1 & 1.11 & 3 & 0.29 & -0.06 & -0.17 & .0 .34 & -0.41 \\
\hline$w$ & 0.79 & 4 & 0.19 & -0.34 & -0.39 & 0.05 & -0.42 \\
\hline c & 0.41 & 5 & .0 .02 & .0 .02 & -0.03 & 0.09 & 0.01 \\
\hline
\end{tabular}

(3) $\alpha_{h}=1, \alpha_{g 7}=-1, \sigma_{h}=0.0075$

\begin{tabular}{|c|c|c|c|c|c|c|c|}
\hline \multirow[t]{2}{*}{ Var. } & \multirow{2}{*}{$\begin{array}{l}\mathrm{SD} \\
\%\end{array}$} & \multirow{2}{*}{$\begin{array}{c}\text { Rank } \\
\text { SD }\end{array}$} & \multirow{2}{*}{$\begin{array}{l}\text { Diff } \\
\text { SD }\end{array}$} & \multicolumn{3}{|c|}{ Corr. With $y(t j)$} & \multirow{2}{*}{$\begin{array}{c}\text { Auto } \\
1\end{array}$} \\
\hline & & & & -1 & 0 & 1 & \\
\hline inv. & 3.56 & 1 & -0.20 & 0.08 & 0.00 & 0.05 & 0.06 \\
\hline$y$ & 1.28 & 2 & .0 .07 & 0.07 & 0.00 & 0.07 & 0.07 \\
\hline 1 & 1.14 & 3 & 0.03 & 0.10 & -0.06 & -0.11 & -0.06 \\
\hline$w$ & 0.87 & 4 & 0.08 & -0.15 & -0.08 & 0.10 & -0.11 \\
\hline c & 0.39 & 5 & .0 .02 & 0.00 & 0.00 & 0.11 & 0.01 \\
\hline
\end{tabular}

(5) $\alpha_{h}=1, \alpha_{y y}=-0.5, \alpha_{E}=-0.5, \sigma_{h}=0.75$

\begin{tabular}{|c|c|c|c|c|c|c|c|}
\hline Var. & SD & Rank & Diff & \multicolumn{3}{|c|}{ Corr. With y(t+j) } & Auto \\
\cline { 5 - 7 } & $\%$ & SD & SD & -1 & 0 & 1 & I \\
\hline inv. & 3.58 & 1 & -0.18 & 0.07 & 0.00 & 0.07 & 0.08 \\
\hline$y$ & 1.31 & 2 & -0.05 & 0.06 & 0.00 & 0.06 & 0.06 \\
\hline I & 0.92 & 3 & -0.19 & 0.16 & 0.02 & 0.11 & 0.17 \\
\hline w & 0.75 & 4 & -0.05 & 0.03 & 0.16 & 0.06 & 0.06 \\
\hline c & 0.41 & 5 & 0.00 & 0.02 & 0.02 & 0.03 & 0.00 \\
\hline
\end{tabular}

\section{(7)CEE Rule}

\begin{tabular}{|c|c|c|c|c|c|c|c|}
\hline Var. & SD & Rank & Diff & \multicolumn{2}{|c|}{ Cor. With y( $(+j)$} & Auto \\
\cline { 5 - 7 } & $\%$ & SD & SD & -1 & 0 & 1 & 1 \\
\hline inv. & 3.75 & 1 & -0.01 & 0.00 & 0.00 & 0.01 & 0.01 \\
\hline$y$ & 1.36 & 2 & 0.00 & 0.00 & 0.00 & 0.00 & 0.00 \\
\hline l & 1.02 & 3 & -0.09 & 0.02 & 0.03 & 0.08 & 0.09 \\
\hline w & 0.74 & 4 & -0.05 & 0.07 & 0.10 & -0.01 & 0.08 \\
\hline c & 0.42 & 5 & 0.01 & 0.01 & 0.01 & -0.02 & 0.00 \\
\hline
\end{tabular}

(2) AR-I Rule( $\left.\alpha_{b}=1, \alpha_{h t}=0.42, \sigma_{b}=.0075\right)$

compared to the same model under

Constant M Growtb, witbout $M$ dist.

\begin{tabular}{|c|c|c|c|c|c|c|c|}
\hline Var. & SD & Rank & Diff & \multicolumn{2}{|c|}{ Cor. With y } & (t+j) & Auto \\
\cline { 5 - 7 } & $\%$ & SD & SD & -1 & 0 & 1 & 1 \\
\hline inv. & 3.76 & 1 & 0.31 & -0.12 & 0.00 & -0.12 & -0.14 \\
\hline y & 1.35 & 2 & 0.08 & -0.10 & 0.00 & -0.10 & -0.10 \\
\hline I & 1.11 & 3 & 0.34 & -0.39 & -0.06 & -0.23 & -0.39 \\
\hline w & 0.79 & 4 & 0.08 & -0.02 & -0.27 & -0.12 & -0.10 \\
\hline c & 0.41 & 5 & 0.00 & 0.06 & -0.04 & -0.05 & 0.00 \\
\hline
\end{tabular}

(4) $\alpha_{h}=1, \alpha_{8}=-0.9, \sigma_{h}=0.0075$

\begin{tabular}{|c|c|c|c|r|r|r|r|}
\hline Var. & SD & Rank & Diff & \multicolumn{3}{|c|}{ Corr. With y(t+j) } & Auto \\
\cline { 5 - 8 } & $\%$ & SD & SD & -1 & 0 & 1 & J \\
\hline inv. & 3.81 & 1 & 0.05 & -0.02 & 0.00 & 0.00 & 0.00 \\
\hline y & 1.39 & 2 & 0.03 & -0.02 & 0.00 & -0.02 & -0.02 \\
\hline l & 0.93 & 3 & -0.18 & 0.01 & 0.10 & 0.21 & 0.22 \\
\hline w & 0.67 & 4 & -0.13 & 0.22 & 0.24 & -0.05 & 0.25 \\
\hline c & 043 & 5 & 0.02 & 0.02 & 0.02 & -0.07 & -0.01 \\
\hline
\end{tabular}

(6) SZ Rule

\begin{tabular}{|c|c|c|c|c|c|c|c|}
\hline Var. & SD & Rank & Diff & \multicolumn{2}{|c|}{ Cor. With y(t+j) } & Auto \\
\cline { 5 - 7 } & $\%$ & SD & SD & -1 & 0 & 1 & 1 \\
\hline inv. & 3.68 & 1 & -0.08 & 0.03 & 0.00 & 0.03 & 0.03 \\
\hline y & 1.33 & 2 & -0.02 & 0.03 & 0.00 & 0.03 & 0.03 \\
\hline I & 1.03 & 3 & -0.08 & 0.06 & 0.00 & 0.04 & 0.06 \\
\hline w & 0.77 & 4 & -0.02 & 0.01 & 0.06 & 0.03 & 0.02 \\
\hline c & 0.41 & 5 & 0.00 & 0.01 & 0.01 & 0.01 & 0.0 \\
\hline
\end{tabular}

(8) SZ Rule (79:4-)

\begin{tabular}{|c|c|c|c|c|c|c|c|}
\hline Var. & SD & Rank & Diff & \multicolumn{2}{|c|}{ Corr. With y(t+j) } & Auto \\
\cline { 5 - 7 } & $\%$ & SD & SD & -1 & 0 & 1 & 1 \\
\hline inv. & 3.71 & 1 & -0.05 & 0.02 & 0.00 & 0.03 & 0.03 \\
\hline y & 1.35 & 2 & 0.00 & 0.01 & 0.00 & 0.01 & 0.01 \\
\hline I & 0.92 & 3 & -0.20 & 0.08 & 0.07 & 0.18 & 0.22 \\
\hline w & 0.70 & 4 & -0.10 & 0.15 & 0.21 & 0.00 & 0.17 \\
\hline c & 0.42 & 5 & 0.01 & 0.02 & 0.02 & -0.03 & 0.00 \\
\hline
\end{tabular}


Table 7. Changes in Population Moments-Multi-Period Nominal Wage Contract Model, compared to the AR-1 Rule with Monetary Disturbances

(1) AR-1 Rule $\left(\alpha_{h}=1, \alpha_{b 1}=0.42, \sigma_{h}=.0075\right)$ compared to the RBC model under Constant Money Growth Rate Rule without Monetary Disturbances

\begin{tabular}{|c|c|c|c|c|c|c|c|}
\hline \multirow[t]{2}{*}{ var. } & \multirow{2}{*}{$\begin{array}{l}\text { SD } \\
\%\end{array}$} & \multirow{2}{*}{$\begin{array}{c}\text { Rank } \\
\text { SD }\end{array}$} & \multirow{2}{*}{$\begin{array}{l}\text { Diff } \\
\text { SD }\end{array}$} & \multicolumn{3}{|c|}{ Corr. With $y(t+j)$} & \multirow{2}{*}{$\begin{array}{c}\text { Auto } \\
1\end{array}$} \\
\hline & & & & -1 & 0 & 1 & \\
\hline nv. & 3.32 & 1 & -0.49 & 0.02 & 0 & 0.01 & 0.01 \\
\hline$y$ & & & & & & & 2 \\
\hline 1 & 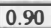 & & & 7 & 4 & 7 & 15 \\
\hline$w$ & 0 & & & 2 & 2 & -0.01 & 2 \\
\hline c & 0.39 & 5 & -0.04 & -0.01 & 0.00 & 0.06 & 0.00 \\
\hline
\end{tabular}

(3) $\alpha_{b}=1, \alpha_{g 7}=-1, \sigma_{b}=0.0075$

\begin{tabular}{|c|c|c|c|c|c|c|c|}
\hline \multirow[t]{2}{*}{ Var. } & \multirow{2}{*}{$\begin{array}{l}\mathrm{SD} \\
\%\end{array}$} & \multirow{2}{*}{$\begin{array}{c}\text { Rank } \\
\text { SD }\end{array}$} & \multirow{2}{*}{$\begin{array}{l}\text { Diff } \\
\text { SD }\end{array}$} & \multicolumn{3}{|c|}{ Corr. With $y(t+j)$} & \multirow{2}{*}{$\begin{array}{c}\text { Auto } \\
\text { I }\end{array}$} \\
\hline & & & & -1 & 0 & 1 & \\
\hline inv. & 2.97 & 1 & -0.35 & 0.13 & 0.00 & 0.10 & 0.12 \\
\hline$y$ & 1.10 & 2 & -0.12 & 0.10 & 0.00 & 0.10 & 0.10 \\
\hline 1 & 0.92 & 3 & 0.02 & 0.15 & -0.14 & -0.09 & 0.09 \\
\hline$w$ & 0.49 & 4 & -0.04 & 0.11 & .0 .02 & 0.06 & 0.10 \\
\hline c & 036 & 5 & -0.03 & 0.01 & 0.00 & 0.11 & 0.00 \\
\hline
\end{tabular}

(5) $\alpha_{h}=1, \alpha_{y y}=-0.5, \alpha_{x}=-0.5, \sigma_{h}=0.75$

\begin{tabular}{|c|c|c|c|c|c|c|c|}
\hline Var. & SD & Ralk & Diff & \multicolumn{3}{|c|}{ Corr. With $y(t+j)$} & Auto \\
\cline { 4 - 7 } & $\%$ & SD & SD & -1 & 0 & 1 & I \\
\hline inv. & 3.18 & 1 & -0.14 & 0.03 & 0.00 & 0.03 & 0.03 \\
\hline$y$ & 1.18 & 2 & -0.04 & 0.02 & 0.00 & 0.02 & 0.02 \\
\hline I & 0.73 & 3 & -0.16 & 0.09 & 0.02 & 0.06 & 0.10 \\
\hline w & 0.52 & 4 & -0.02 & 0.03 & 0.00 & 0.02 & 0.03 \\
\hline $\mathrm{c}$ & 0.39 & 5 & 0.00 & 0.01 & 0.02 & 0.02 & 0.00 \\
\hline
\end{tabular}

\section{(7) CEE Rule}

\begin{tabular}{|c|c|c|c|c|c|c|r|}
\hline Var. & SD & Rank & Diff & \multicolumn{2}{|c|}{ Cor. With y(1+j) } & Auto \\
\cline { 5 - 7 } & $\%$ & SD & SD & -1 & 0 & I & I \\
\hline inv. & 3.37 & I & 0.05 & -0.02 & 0.00 & -0.01 & -0.02 \\
\hline$y$ & 1.24 & 2 & 0.02 & -0.02 & 0.00 & -0.02 & -0.02 \\
\hline I & 0.83 & 3 & -0.06 & -0.01 & 0.05 & 0.05 & 0.00 \\
\hline w & 0.54 & 4 & 0.01 & -0.02 & 0.00 & -0.01 & -0.01 \\
\hline c & 0.40 & 5 & 0.01 & 0.00 & 0.01 & -0.02 & 0.00 \\
\hline
\end{tabular}

(2) AR-1 Rule( $\left.\alpha_{h}=1, \alpha_{h]}=0.42, \sigma_{h}=.0075\right)$

compared to the same model under Constant M Growth, without $M$ dist.

\begin{tabular}{|c|c|c|c|c|c|c|c|}
\hline Var. & SD & Rank & Diff & \multicolumn{3}{|c|}{ Corr. With y(t+j) } & Auto \\
\cline { 5 - 7 } & $\%$ & SD & SD & -1 & 0 & 1 & I \\
\hline inv. & 3.32 & 1 & 0.24 & -0.05 & 0.00 & -0.05 & .0 .06 \\
\hline y & 1.22 & 2 & 0.06 & -0.04 & 0.00 & -0.04 & -0.04 \\
\hline I & 0.90 & 3 & 0.30 & -0.21 & -0.06 & -0.13 & -0.26 \\
\hline w & 0.54 & 4 & 0.04 & -0.05 & 0.01 & -0.04 & -0.06 \\
\hline c & 0.39 & 5 & 0.00 & -0.03 & -0.03 & -0.04 & 0.00 \\
\hline
\end{tabular}

(4) $\alpha_{h}=1, \alpha_{k}=-0.9, \sigma_{h}=0.0075$

\begin{tabular}{|c|c|c|c|c|c|c|c|}
\hline Var. & SD & Rank & Diff & \multicolumn{3}{|c|}{ Corr. With y(t+j) } & Auto \\
\cline { 5 - 7 } & \% & SD & SD & -1 & 0 & I & I \\
\hline inv. & 3.52 & 1 & 0.20 & -0.07 & 0.00 & -0.05 & -0.06 \\
\hline y & 1.29 & 2 & 0.08 & -0.05 & 0.00 & -0.05 & -0.05 \\
\hline I & 0.79 & 3 & -0.11 & -0.07 & 0.14 & 0.12 & -0.06 \\
\hline w & 0.56 & 4 & 0.02 & -0.06 & 0.01 & -0.03 & -0.05 \\
\hline c & 0.41 & 5 & 0.02 & 0.00 & 0.01 & -0.06 & 0.00 \\
\hline
\end{tabular}

(6) SZ Rule

\begin{tabular}{|c|c|c|c|c|c|c|c|}
\hline Var. & SD & Rank & Diff & \multicolumn{3}{|c|}{ Corr. Wi h y(t+j) } & Auto \\
\cline { 5 - 7 } & \% & SD & SD & -1 & 0 & I & I \\
\hline inv. & 3.25 & 1 & -0.07 & 0.01 & 0.00 & 0.01 & 0.02 \\
\hline y & 1.20 & 2 & -0.02 & 0.01 & 0.00 & 0.01 & 0.01 \\
\hline I & 0.83 & 3 & -0.07 & 0.04 & 0.00 & 0.02 & 0.04 \\
\hline w & 0.53 & 4 & -0.01 & 0.01 & 0.00 & 0.01 & 0.02 \\
\hline c & 0.39 & 5 & 0.00 & 0.01 & 0.01 & 0.01 & 0.00 \\
\hline
\end{tabular}

\section{(8) SZ Rule (79:4-)}

\begin{tabular}{|c|c|c|c|c|c|c|c|}
\hline Var. & SD & Rank & Diff & \multicolumn{2}{|c|}{ Corr. With y(t+j) } & Auto \\
\cline { 5 - 8 } & $\%$ & SD & SD & -1 & 0 & I & 1 \\
\hline inv. & 3.32 & 1 & 0.00 & 0.00 & 0.00 & 0.00 & 0.00 \\
\hline y & 1.22 & 2 & 0.00 & 0.00 & 0.00 & 0.00 & 0.00 \\
\hline I & 0.90 & 3 & 0.00 & 0.00 & 0.00 & 0.00 & 0.00 \\
\hline w & 0.54 & 4 & 0.00 & 0.00 & 0.00 & 0.00 & 0.00 \\
\hline c & 0.39 & 5 & 0.00 & 0.00 & 0.00 & 0.00 & 0.00 \\
\hline
\end{tabular}


Table 8. Changes in Population Moments-Monopolistic Competition Model, with Price Adjustment Cost $\left(\phi_{p}=1\right)$, comparcd to the AR-1 Rule with Monetary Disturbances

(1) AR-1 Rule $\left(\alpha_{h}=1, \alpha_{h l}=0.42, \sigma_{h}=.0075\right)$ compared to the RBC model under Constant Money Growth Rate Rule without Monewary Disturbances

\begin{tabular}{|c|c|c|c|c|c|c|c|}
\hline \multirow[t]{2}{*}{ Var. } & \multirow{2}{*}{$\begin{array}{l}\mathrm{SD} \\
\%\end{array}$} & \multirow{2}{*}{$\begin{array}{c}\text { Rank } \\
\text { SD }\end{array}$} & \multirow{2}{*}{$\begin{array}{l}\text { Diff } \\
\text { SD }\end{array}$} & \multicolumn{3}{|c|}{ Cors. With y $(t+j)$} & \multirow{2}{*}{$\begin{array}{c}\text { Auto } \\
1\end{array}$} \\
\hline & & & & -1 & 0 & I & \\
\hline inv. & 3.62 & 1 & -0.18 & 0.09 & 0.00 & 0.06 & 0.08 \\
\hline$y$ & 1.44 & 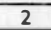 & -0.06 & 0.07 & 0. & 0.07 & .07 \\
\hline 1 & 0.60 & 4 & 0.00 & 0.19 & .0 .10 & -0.08 & 0.05 \\
\hline w & 0.67 & 3 & -0.03 & 0.06 & 0.00 & 0.06 & 0.05 \\
\hline 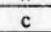 & 0.56 & 5 & .0 .02 & 0.00 & 0.00 & 0.07 & 0.00 \\
\hline
\end{tabular}

(3) $\alpha_{b}=1, \alpha_{y y}=-1, \sigma_{h}=0.0075$

\begin{tabular}{|c|c|c|c|c|c|c|c|}
\hline \multirow[t]{2}{*}{ Var. } & \multirow{2}{*}{$\begin{array}{c}\mathrm{SD} \\
\%\end{array}$} & \multirow{2}{*}{$\begin{array}{c}\text { Rank } \\
\text { SD }\end{array}$} & \multirow{2}{*}{$\begin{array}{l}\text { Diff } \\
\text { SD }\end{array}$} & \multicolumn{3}{|c|}{ Corr. With y $(t+j)$} & \multirow{2}{*}{$\begin{array}{c}\text { Auto } \\
1\end{array}$} \\
\hline & & & & -1 & 0 & 1 & \\
\hline inv. & 3.36 & 1 & -0.26 & 0.07 & 0.00 & 04 & 0.06 \\
\hline$y$ & 1.35 & 2 & .09 & 0.05 & 0.00 & 5 & .05 \\
\hline 1 & 0.57 & 4 & .0 .02 & 0.12 & -0.12 & -0.14 & -0.08 \\
\hline w & 0.63 & 3 & -0.04 & 0.04 & 0.00 & 0.05 & 0.04 \\
\hline c & 0.54 & 5 & -0.02 & 0.00 & 0.01 & 0.07 & 0.00 \\
\hline
\end{tabular}

(5) $\alpha_{b}=1, \alpha_{y y}=-0.5, \alpha_{R}=-0.5, \sigma_{h}=0.75$

\begin{tabular}{|c|c|c|c|c|c|c|c|}
\hline Var. & SD & Rank & Diff & \multicolumn{2}{|c|}{ Cor. With y(t+j) } & Auto \\
\cline { 5 - 7 } & $\%$ & SD & SD & -1 & 0 & 1 & 1 \\
\hline inv. & 3.57 & 1 & -0.05 & 0.01 & 0.00 & 0.01 & 0.01 \\
\hline$y$ & 1.42 & 2 & -0.01 & 0.00 & 0.00 & 0.00 & 0.00 \\
\hline 1 & 0.53 & $5^{*}$ & -0.06 & 0.07 & 0.04 & 0.05 & 0.06 \\
\hline w & 0.67 & 3 & 0.00 & 0.00 & 0.00 & 0.00 & 0.00 \\
\hline c & 0.56 & $4^{*}$ & 0.00 & 0.00 & 0.01 & 0.01 & 0.00 \\
\hline
\end{tabular}

\section{(7) CE E Rule}

\begin{tabular}{|c|c|c|c|c|c|c|c|}
\hline Var. & SD & Rank & Diff & \multicolumn{3}{|c|}{ Cor. With y(t+j) } & Auto \\
\cline { 5 - 7 } & $\%$ & SD & SD & -1 & 0 & 1 & 1 \\
\hline inv. & 3.62 & 1 & 0.00 & -0.01 & 0.00 & -0.01 & -0.01 \\
\hline y & 1.44 & 2 & 0.01 & -0.01 & 0.00 & -0.01 & -0.01 \\
\hline I & 0.55 & $5^{*}$ & -0.04 & 0.01 & 0.05 & 0.05 & 0.03 \\
\hline w & 0.68 & 3 & 0.00 & -0.01 & 0.00 & -0.01 & -0.01 \\
\hline c & 0.56 & $4^{*}$ & 0.00 & 0.00 & 0.00 & -0.01 & 0.00 \\
\hline
\end{tabular}

(2) AR-I Rule( $\left.\alpha_{h}=1, \alpha_{h 1}=0.42, \sigma_{h}=.0075\right)$ compared to the same model under Constant M Growth, without M dist.

\begin{tabular}{|c|c|c|c|c|c|c|c|}
\hline \multirow[t]{2}{*}{ Var. } & \multirow{2}{*}{$\begin{array}{l}\text { SD } \\
\%\end{array}$} & \multirow{2}{*}{$\begin{array}{c}\text { Rank } \\
\text { SD }\end{array}$} & \multirow{2}{*}{$\begin{array}{l}\text { Diff } \\
\text { SD }\end{array}$} & \multicolumn{3}{|c|}{ Corr. With y $[i+j)$} & \multirow{2}{*}{$\begin{array}{c}\text { Auto } \\
1\end{array}$} \\
\hline & & & & -1 & 0 & 1 & \\
\hline inv. & 3.62 & T & 0.06 & -0.01 & 0.00 & -0.01 & -0.01 \\
\hline$y$ & 1.44 & 2 & 0.01 & 0.01 & 0.00 & 11 & .01 \\
\hline 1 & 0.60 & 4 & 0.08 & -0.10 & -0.06 & -0.07 & -0.11 \\
\hline w & 0.67 & 3 & 0.01 & .0 .01 & 0.00 & -0.01 & -0.01 \\
\hline c & 0.56 & $\overline{5}$ & 0.00 & -0.01 & -0.01 & -0.01 & 0.00 \\
\hline
\end{tabular}

(4) $\alpha_{h}=1, \alpha_{x}=-0.9, \sigma_{h}=0.0075$

\begin{tabular}{|c|c|c|c|c|c|c|c|}
\hline \multirow[t]{2}{*}{ Var. } & \multirow{2}{*}{$\begin{array}{l}S D \\
\%\end{array}$} & \multirow{2}{*}{$\begin{array}{c}\text { Rank } \\
\text { SD }\end{array}$} & \multirow{2}{*}{$\begin{array}{l}\text { Diff } \\
\text { SD }\end{array}$} & \multicolumn{3}{|c|}{ Corr. With y $(t+j)$} & \multirow{2}{*}{$\begin{array}{c}\text { Auto } \\
1\end{array}$} \\
\hline & & & & -1 & 0 & 1 & \\
\hline inv. & 3.67 & 1 & 0.06 & -0.03 & 0.00 & -0.02 & -0.03 \\
\hline$y$ & 1.46 & 2 & 0.02 & -0.03 & 0.00 & -0.03 & -0.03 \\
\hline 1 & 0.55 & $5^{*}$ & -0.05 & -0.03 & 0.09 & 0.09 & 0.05 \\
\hline w & 0.68 & 3 & 0.01 & -0.02 & 0.00 & -0.02 & -0.02 \\
\hline c & 0.57 & $4^{\circ}$ & 0.01 & 0.00 & 0.00 & -0.03 & 0.00 \\
\hline
\end{tabular}

(6) SZ Rule

\begin{tabular}{|c|c|c|c|c|c|c|c|}
\hline Var. & SD & Rank & Diff & \multicolumn{3}{|c|}{ Corr. With y(t+j) } & Auto \\
\cline { 5 - 7 } & $\%$ & SD & SD & -1 & 0 & 1 & 1 \\
\hline inv. & 3.53 & 1 & -0.08 & 0.00 & 0.00 & 0.00 & 0.00 \\
\hline y & 1.41 & 2 & -0.02 & 0.00 & 0.00 & 0.00 & 0.00 \\
\hline I & 0.53 & $5^{*}$ & -0.06 & 0.05 & 0.03 & 0.02 & 0.02 \\
\hline w & 0.66 & 3 & -0.01 & 0.00 & 0.00 & 0.00 & 0.00 \\
\hline c & 0.56 & $4^{*}$ & 0.00 & 0.00 & 0.01 & 0.01 & 0.00 \\
\hline
\end{tabular}

(8) SZ Rule (79:4-)

\begin{tabular}{|c|c|c|c|c|c|c|c|}
\hline \multirow[t]{2}{*}{$\overline{V a r}}$. & \multirow{2}{*}{$\begin{array}{l}\text { SD } \\
\%\end{array}$} & \multirow{2}{*}{$\begin{array}{c}\text { Rank } \\
\text { SD }\end{array}$} & \multirow{2}{*}{$\begin{array}{l}\text { Diff } \\
\text { SD }\end{array}$} & \multicolumn{3}{|c|}{ Corr. Wish y $(t+j)$} & \multirow{2}{*}{$\begin{array}{c}\text { Auto } \\
1\end{array}$} \\
\hline & & & & -1 & 0 & I & \\
\hline inv. & 3.42 & 1 & -0.19 & 0.00 & 0.00 & 0.00 & $\overline{0.00}$ \\
\hline$y$ & 1.38 & 2 & -0.06 & 0.00 & 0.00 & 0.00 & $0.0(1)$ \\
\hline 1 & 0.51 & $5 *$ & -0.09 & 0.03 & -0.02 & -0.02 & 0.0 \\
\hline$w$ & 0.65 & 3 & -0.03 & 0.00 & 0.00 & 0.00 & 0.0 \\
\hline c & 0.55 & $4^{*}$ & -0.01 & 0.00 & 0.00 & 0.00 & 0.00 \\
\hline
\end{tabular}


rable 9. Changes in Population Moments-Monopolistic Competition Model, with Price Adjustment Cost ( $\phi_{\mathrm{p}}=5$ ), compared to the AR-1 Rule with Monetary Disturbances

(1) AR-1 Rule $\left(\alpha_{b}=1, \alpha_{h 1}=0.42, \sigma_{b}=.0075\right)$ sompared to the RBC model under Constant Money Growth Rate Rule without Monetary Disturbances

\begin{tabular}{|c|c|c|c|c|c|c|c|}
\hline \multirow[t]{2}{*}{ Var. } & \multirow{2}{*}{$\begin{array}{l}\text { SD } \\
\%\end{array}$} & \multirow{2}{*}{$\begin{array}{c}\text { Rank } \\
\text { SD }\end{array}$} & \multirow{2}{*}{$\begin{array}{l}\text { Diff } \\
\text { SD }\end{array}$} & \multicolumn{3}{|c|}{ Corr. With y(t+i) } & \multirow{2}{*}{$\begin{array}{c}\text { Auto } \\
1\end{array}$} \\
\hline & & & & -1 & 0 & 1 & \\
\hline inv. & 3.72 & T & -0.07 & 0.15 & -0.01 & $\overline{0.0}$ & 0.11 \\
\hline $\bar{Y}$ & 1.35 & 2 & .0 .15 & 0.1 & 0.00 & 0. & 0 \\
\hline $\mathrm{L}$ & 1.34 & 3 & 0.75 & 0.04 & -0.33 & -0.35 & -0.07 \\
\hline W & 0.61 & 4 & 0.09 & 0.11 & -0.01 & 0.11 & 0.11 \\
\hline $\mathrm{C}$ & 0.50 & 5 & -0.08 & -0.13 & -0.17 & 0.07 & -0.03 \\
\hline
\end{tabular}

(3) $\alpha_{h}=1, \alpha_{y y}=-1, \sigma_{h}=0.0075$

\begin{tabular}{|c|c|c|c|c|c|c|c|}
\hline \multirow[t]{2}{*}{ Var. } & \multirow{2}{*}{$\begin{array}{l}\text { SD } \\
\%\end{array}$} & \multirow{2}{*}{$\begin{array}{c}\text { Rank } \\
\text { SD }\end{array}$} & \multirow{2}{*}{$\begin{array}{l}\text { Diff } \\
\text { SD }\end{array}$} & \multicolumn{3}{|c|}{ Corr. With y $(t+j)$} & \multirow{2}{*}{$\begin{array}{c}\text { Auto } \\
1\end{array}$} \\
\hline & & & & .1 & 0 & 1 & \\
\hline nv. & 2.45 & 1 & -1.27 & 0.08 & -0.02 & .0 .02 & 0.03 \\
\hline$y$ & 0.92 & $2^{\circ}$ & -0.43 & 0.04 & 0.00 & 0.04 & 0.04 \\
\hline 1 & 1.18 & $3^{*}$ & .0 .16 & .0 .14 & .0 .33 & .0 .36 & -0.05 \\
\hline $\bar{w}$ & 0.41 & $5^{\circ}$ & -0.20 & 0.01 & 0.00 & 0.06 & 0.03 \\
\hline c & 0.43 & $4^{*}$ & -0.07 & -0.14 & -0.04 & 0.10 & -0.08 \\
\hline
\end{tabular}

(5) $\alpha_{\hbar}=1, \alpha_{y y}=-0.5, \alpha_{x}=-0.5, \sigma_{\hbar}=0.75$

\begin{tabular}{|c|c|c|c|c|c|c|c|}
\hline Var. & SD & Rank & Diff & \multicolumn{3}{|c|}{ Corr. With y $(t+j)$} & Auto \\
\cline { 4 - 8 } & $\%$ & SD & SD & -1 & 0 & 1 & 1 \\
\hline nv. & 2.98 & 1 & -0.74 & 0.05 & 0.00 & 0.02 & 0.04 \\
\hline$y$ & 1.17 & 2 & -0.18 & 0.03 & 0.00 & 0.03 & 0.03 \\
\hline I & 0.92 & 3 & -0.43 & 0.00 & -0.18 & -0.22 & -0.13 \\
\hline w & 0.54 & 4 & -0.07 & 0.01 & 0.00 & 0.03 & 0.01 \\
\hline c & 0.48 & 5 & -0.01 & 0.05 & 0.11 & 0.14 & -0.01 \\
\hline
\end{tabular}

(7) CEE Rule

\begin{tabular}{|c|c|c|c|c|c|c|c|}
\hline \multirow[t]{2}{*}{ Var. } & \multirow{2}{*}{$\begin{array}{c}\mathrm{SD} \\
\%\end{array}$} & \multirow{2}{*}{$\begin{array}{c}\text { Rank } \\
\text { SD }\end{array}$} & \multirow{2}{*}{$\begin{array}{l}\text { Diff } \\
\text { SD }\end{array}$} & \multicolumn{3}{|c|}{ Cort. With y $(i+j)$} & \multirow{2}{*}{$\begin{array}{c}\text { Auto } \\
1\end{array}$} \\
\hline & & & & .1 & 0 & 1 & \\
\hline inv. & 3.33 & 1 & -0.40 & 0.00 & 0.01 & .0 .01 & .0 .01 \\
\hline$y$ & 1.28 & 2 & -0.07 & .0 .01 & 0.00 & .0 .01 & -0.01 \\
\hline 1 & 0.99 & 3 & -0.36 & -0.01 & -0.07 & -0.12 & -0.15 \\
\hline$w$ & 0.59 & 4 & -0.02 & -0.02 & 0.00 & 0.00 & -0.01 \\
\hline & 0.50 & 5 & 0.00 & 0.06 & 0.10 & 0.09 & 0.00 \\
\hline
\end{tabular}

(2) AR-1 Rule $\left(\alpha_{b}=1, \alpha_{h}=0.42, \sigma_{h}=.0075\right)$ compared to the same model under Constant M Growth, without M dist.

\begin{tabular}{|c|c|c|c|c|c|c|c|}
\hline Var. & SD & Rank & Diff & \multicolumn{2}{|c|}{ Corr. With y(t+j) } & Auto \\
\cline { 5 - 6 } & $\%$ & SD & SD & -1 & 0 & 1 & 1 \\
\hline inv & 3.72 & 1 & 0.94 & -0.11 & -0.01 & -0.06 & -0.10 \\
\hline$y$ & 1.35 & 2 & 0.23 & -0.06 & 0.00 & -0.06 & -0.06 \\
\hline 1 & 1.34 & 3 & 0.56 & -0.08 & 0.26 & 0.27 & 0.12 \\
\hline w & 0.61 & 4 & 0.09 & -0.04 & 0.00 & -0.07 & -0.04 \\
\hline c & 0.50 & 5 & 0.02 & -0.06 & -0.15 & -0.18 & 0.01 \\
\hline
\end{tabular}

(4) $\alpha_{n}=1, \alpha_{n}=-0.9, \sigma_{b}=0.0075$

\begin{tabular}{|c|c|c|c|c|c|c|c|}
\hline \multirow[t]{2}{*}{ Var. } & \multirow{2}{*}{$\begin{array}{l}\text { SD } \\
\%\end{array}$} & \multirow{2}{*}{$\begin{array}{c}\text { Rank } \\
\text { SD }\end{array}$} & \multirow{2}{*}{$\begin{array}{l}\text { Diff } \\
\text { SD }\end{array}$} & \multicolumn{3}{|c|}{ Corr. With y $(t+j)$} & \multirow{2}{*}{$\begin{array}{c}\text { Auto } \\
1\end{array}$} \\
\hline & & & & -1 & 0 & 1 & \\
\hline inv. & 3.36 & 1 & -0.36 & 0.00 & 0.01 & 0.00 & 0.00 \\
\hline$y$ & 1.33 & 2 & -0.02 & -0.02 & 0.00 & -0.02 & -0.02 \\
\hline 1 & 0.74 & 3 & -0.60 & 0.09 & 0.01 & -0.02 & -0.14 \\
\hline$w$ & 0.62 & 4 & 0.01 & -0.02 & 0.01 & -0.01 & -0.02 \\
\hline c & 0.53 & 5 & 0.03 & 0.11 & 0.16 & 0.09 & 0.02 \\
\hline
\end{tabular}

(6) SZ Rule

\begin{tabular}{|c|c|c|c|c|c|c|c|}
\hline \multirow[t]{2}{*}{ Var. } & \multirow{2}{*}{$\begin{array}{l}\text { SD } \\
\%\end{array}$} & \multirow{2}{*}{$\begin{array}{c}\text { Rank } \\
\text { SD }\end{array}$} & \multirow{2}{*}{$\begin{array}{l}\text { Diff } \\
\text { SD }\end{array}$} & \multicolumn{3}{|c|}{ Corr. With y $(i+j)$} & \multirow{2}{*}{$\begin{array}{c}\text { Auto } \\
1\end{array}$} \\
\hline & & & & -1 & 0 & 1 & \\
\hline inv. & 3.15 & 1 & .0 .57 & 0.01 & 0.00 & -0.01 & .0 .01 \\
\hline$y$ & 1.21 & 2 & -0.14 & 0.00 & 0.00 & 0.00 & 0.00 \\
\hline 1 & 1.00 & 3 & .0 .34 & .0 .03 & .0 .13 & -0.20 & -0.17 \\
\hline$w$ & 0.56 & 4 & -0.05 & -0.01 & 0.00 & 0.01 & 0.00 \\
\hline c & 0.49 & 5 & -0.01 & 0.04 & 0.09 & 0.12 & -0.01 \\
\hline
\end{tabular}

(8) SZ Rule (79:4-)

\begin{tabular}{|c|c|c|c|c|c|c|c|}
\hline Var. & SD & Rank & Diff & \multicolumn{3}{|c|}{ Corr. With $y(t+j)$} & Auto \\
\cline { 5 - 7 } & $\%$ & SD & SD & -1 & 0 & 1 & I \\
\hline inv. & 3.01 & 1 & -0.71 & -0.02 & 0.00 & -0.05 & -0.04 \\
\hline$y$ & 1.15 & 2 & -0.20 & -0.03 & 0.00 & -0.03 & -0.03 \\
\hline 1 & 1.05 & 3 & -0.29 & -0.13 & -0.18 & -0.23 & -0.13 \\
\hline w & 0.53 & 4 & -0.08 & -0.04 & 0.01 & -0.01 & -0.03 \\
\hline c & 0.48 & 5 & -0.02 & 0.00 & 0.07 & 0.07 & -0.03 \\
\hline
\end{tabular}


Table 10. Changes in Population Moments-Monopolistic Competition Model, with Price Adjustment Cost $\left(\phi_{p}=15\right.$ ), compared to the AR-1 Rule with Monetary Disturbances

(1) AR-1 Rule $\left(\alpha_{b}=1, \alpha_{b \mid}=0.42, \sigma_{k}=.0075\right)$ compared to the RBC model with Coustant Money Rate Rule without Monetary Disturbances

\begin{tabular}{|c|c|c|c|c|c|c|c|}
\hline \multirow[t]{2}{*}{ Var. } & \multirow{2}{*}{$\begin{array}{l}\text { SD } \\
\%\end{array}$} & \multirow{2}{*}{$\begin{array}{l}\text { Rank } \\
\text { SD }\end{array}$} & \multirow{2}{*}{$\begin{array}{l}\text { Diff } \\
\text { SD }\end{array}$} & \multicolumn{3}{|c|}{ Corr. With y $(c+j)$} & \multirow{2}{*}{$\begin{array}{c}\text { Auto } \\
1\end{array}$} \\
\hline & & & & .1 & 0 & 1 & \\
\hline inv. & 4.36 & 1 & 0.56 & 0.13 & -0.02 & 0.09 & 0.12 \\
\hline$y$ & 1.37 & 3 & -0.13 & 0.13 & 0.00 & 0.13 & 0.13 \\
\hline 1 & 2.10 & 2 & 1.51 & 0.05 & -0.23 & -0.18 & 0.04 \\
\hline$w$ & 0.58 & 4 & -0.12 & 0.12 & -0.04 & 0.07 & 0.13 \\
\hline c & 0.49 & 5 & -0.09 & -0.43 & -0.61 & -0.35 & -0.06 \\
\hline
\end{tabular}

(3) $\alpha_{b}=1, \alpha_{y y}=-1, \sigma_{b}=0.0075$

\begin{tabular}{|c|c|c|c|c|c|c|c|}
\hline \multirow[t]{2}{*}{ Var. } & \multirow{2}{*}{$\begin{array}{l}\text { SD } \\
\%\end{array}$} & \multirow{2}{*}{$\begin{array}{c}\text { Rank } \\
\text { SD }\end{array}$} & \multirow{2}{*}{$\begin{array}{l}\text { Diff } \\
\text { SD }\end{array}$} & \multicolumn{3}{|c|}{ Corr. With y $(t+j)$} & \multirow{2}{*}{$\begin{array}{c}\text { Auto } \\
\text { I }\end{array}$} \\
\hline & & & & -1 & 0 & 1 & \\
\hline inv. & 2.02 & 1 & -2.34 & .0 .06 & .0 .10 & .0 .20 & -0.08 \\
\hline$y$ & 0.59 & 3 & -0.78 & -0.04 & 0.00 & -0.04 & .0 .04 \\
\hline 1 & 1.53 & 2 & -0.57 & -0.28 & -0.41 & .0 .47 & -0.08 \\
\hline$w$ & 0.25 & 5 & .0 .33 & -0.14 & -0.03 & 0.00 & -0.08 \\
\hline c & 0.44 & $4^{4}$ & -0.04 & .0 .26 & .0 .09 & 0.07 & -0.08 \\
\hline
\end{tabular}

(5) $\alpha_{h}=1, \alpha_{y y}=-0.5, \alpha_{x}=-0.5, \sigma_{h}=0.75$

\begin{tabular}{|c|c|c|c|c|c|c|c|}
\hline Var. & SD & Rank & Diff & \multicolumn{3}{|c|}{ Corr. With $y(t+j)$} & Auto \\
\cline { 5 - 7 } & $\%$ & SD & SD & -1 & 0 & 1 & 1 \\
\hline inv. & 2.49 & 1 & -1.87 & 0.01 & -0.03 & -0.11 & -0.05 \\
\hline y & 0.85 & 3 & -0.52 & -0.02 & 0.00 & -0.02 & -0.02 \\
\hline I & 1.43 & 2 & -0.68 & -0.19 & -0.35 & -0.44 & -0.12 \\
\hline w & 0.37 & $5^{*}$ & -0.21 & -0.06 & 0.02 & 0.04 & -0.03 \\
\hline c & 0.42 & $4^{*}$ & -0.06 & -0.02 & 0.18 & 0.31 & -0.07 \\
\hline
\end{tabular}

(7) CEE Rule

\begin{tabular}{|c|c|c|c|c|c|c|c|}
\hline Var. & SD & Rank & Diff & \multicolumn{2}{|c|}{ Cor. With $y(t+j)$} & Auto \\
\cline { 5 - 7 } & $\%$ & SD & SD & -1 & 0 & 1 & I \\
\hline inv. & 3.33 & 1 & -1.03 & -0.04 & -0.01 & -0.10 & -0.08 \\
\hline$y$ & 1.11 & 3 & -0.26 & -0.06 & 0.00 & -0.06 & -0.06 \\
\hline I & 1.63 & 2 & -0.47 & -0.13 & -0.15 & -0.26 & -0.12 \\
\hline w & 0.48 & 4 & -0.10 & -0.07 & 0.02 & -0.01 & -0.05 \\
\hline $\mathrm{c}$ & 0.44 & 5 & -0.04 & 0.05 & 0.18 & 0.25 & -0.04 \\
\hline
\end{tabular}

(2) AR-1 Rule( $\left.\alpha_{b}=1, \alpha_{h 1}=0.42, \sigma_{h}=.0075\right)$ compared to the same model Growth with Const. M Growtb, no M dist.

\begin{tabular}{|c|c|c|c|c|c|c|c|}
\hline \multirow[t]{2}{*}{ Var. } & \multirow{2}{*}{$\begin{array}{l}\text { SD } \\
\%\end{array}$} & \multirow{2}{*}{$\begin{array}{c}\text { Rank } \\
\text { SD }\end{array}$} & \multirow{2}{*}{$\begin{array}{l}\text { Diff } \\
\text { SD }\end{array}$} & \multicolumn{3}{|c|}{ Corr. With y $(t+j)$} & \multirow{2}{*}{$\begin{array}{c}\text { Auto } \\
1\end{array}$} \\
\hline & & & & -1 & 0 & 1 & \\
\hline inv. & 4.36 & $T$ & 2.56 & .0 .18 & 0.06 & 0.06 & -0.08 \\
\hline$y$ & 1.37 & 3 & 0.70 & .0 .10 & 0.00 & -0.10 & -0.10 \\
\hline 1 & 2.10 & 2 & 0.89 & 0.25 & 0.64 & 0.71 & 0.13 \\
\hline$w$ & 0.58 & 4 & 0.28 & -0.01 & .0 .02 & -0.17 & -0.04 \\
\hline c & 0.49 & 5 & 0.07 & 0.00 & -0.30 & -0.50 & 0.09 \\
\hline
\end{tabular}

(4) $\alpha_{\mathrm{w}}=1, \alpha_{\mathrm{z}}=-0.9, \sigma_{\mathrm{h}}=0.0075$

\begin{tabular}{|c|c|c|c|c|c|c|c|}
\hline Var. & SD & Rank & Diff & \multicolumn{2}{|c|}{ Cor. With y(itj) } & Auto \\
\cline { 5 - 7 } & $\%$ & SD & SD & -1 & 0 & 1 & 1 \\
\hline inv. & 3.15 & 1 & -1.21 & -0.01 & 0.00 & -0.08 & -0.06 \\
\hline y & 1.14 & 3 & -0.23 & -0.04 & 0.00 & -0.04 & -0.04 \\
\hline I & 1.33 & 2 & -0.78 & -0.12 & -0.22 & -0.36 & -0.20 \\
\hline w & 0.51 & 4 & -0.07 & -0.05 & 0.03 & 0.02 & -0.04 \\
\hline c & 0.45 & 5 & -0.03 & 0.20 & 0.39 & 0.44 & -0.01 \\
\hline
\end{tabular}

(6) SZ Rule

\begin{tabular}{|c|c|c|c|c|c|c|c|}
\hline Var. & SD & Rank & Diff & \multicolumn{3}{|c|}{ Cor. With y $(1+j)$} & Auto \\
\cline { 5 - 7 } & \% & SD & SD & -1 & 0 & 1 & 1 \\
\hline inv. & 3.01 & 1 & -1.35 & -0.03 & -0.01 & -0.11 & -0.09 \\
\hline y & 1.01 & 3 & -0.36 & -0.05 & 0.00 & -0.05 & -0.05 \\
\hline I & 1.56 & 2 & -0.54 & -0.15 & -0.21 & -0.34 & -0.14 \\
\hline w & 0.43 & 4 & -0.14 & -0.07 & 0.02 & 0.01 & -0.05 \\
\hline c & 0.43 & $4^{\bullet}$ & -0.05 & 0.02 & 0.17 & 0.28 & -0.05 \\
\hline
\end{tabular}

(8) SZ Rule (79:4-)

\begin{tabular}{|c|c|c|c|c|c|c|c|}
\hline Var. & SD & Rank & Diff & \multicolumn{2}{|c|}{ Corr. With y $(t+j)$} & Auto \\
\cline { 5 - 8 } & $\%$ & SD & SD & -1 & 0 & 1 & 1 \\
\hline inv. & 3.09 & 1 & -1.26 & -0.10 & -0.02 & -0.16 & -0.14 \\
\hline y & 1.01 & 3 & -0.35 & -0.11 & 0.00 & -0.11 & -0.11 \\
\hline I & 1.63 & 2 & -0.48 & -0.21 & -0.21 & -0.32 & -0.14 \\
\hline w & 0.43 & $5^{*}$ & -0.15 & -0.12 & -0.12 & -0.05 & -0.10 \\
\hline c & 0.45 & $4^{*}$ & -0.04 & -0.02 & -0.02 & 0.18 & -0.0 \\
\hline
\end{tabular}


Table 11. Changes in Population Moments-with Price Adjustment Cost $\left(\phi_{p}=5\right)$ and One-Period Nominal Wage Contract

(1) AR-1 Rule $\left(\alpha_{h}=1, \alpha_{k 1}=0.42, \sigma_{b}=.0075\right)$ compared to the RBC model under Constant Money Growth Rate Rule without Monetary Disturbances

\begin{tabular}{|c|c|c|c|c|c|c|c|}
\hline \multirow[t]{2}{*}{ Var. } & \multirow{2}{*}{$\begin{array}{l}\text { SD } \\
\%\end{array}$} & \multirow{2}{*}{$\begin{array}{l}\text { Rank } \\
\text { SD }\end{array}$} & \multirow{2}{*}{$\begin{array}{l}\text { Diff } \\
\text { SD }\end{array}$} & \multicolumn{3}{|c|}{ Corr. With $y(t+j)$} & \multirow{2}{*}{$\begin{array}{c}\text { Auto } \\
1\end{array}$} \\
\hline & & & & .1 & 0 & 1 & \\
\hline inv. & 4.20 & 1 & 0.40 & 0.10 & .0 .01 & 0.03 & 0.05 \\
\hline$y$ & 1.45 & 3 & -0.05 & 0.09 & 0.00 & 0.09 & 0.09 \\
\hline 1 & 1.68 & 2 & 1.09 & 0.01 & -0.26 & -0.33 & -0.11 \\
\hline$w$ & 0.64 & 4 & -0.06 & 0.08 & -0.23 & -0.06 & -0.06 \\
\hline c & 0.49 & 5 & -0.09 & -0.19 & -0.27 & 0.00 & -0.03 \\
\hline
\end{tabular}

(3) $\alpha_{h}=1, \alpha_{y y}=-1, \sigma_{h}=0.0075$

\begin{tabular}{|c|c|c|c|c|c|c|c|}
\hline \multirow[t]{2}{*}{ Var. } & \multirow{2}{*}{$\begin{array}{l}\text { SD } \\
\%\end{array}$} & \multirow{2}{*}{$\begin{array}{c}\text { Rank } \\
\text { SD }\end{array}$} & \multirow{2}{*}{$\begin{array}{l}\text { Diff } \\
\text { SD }\end{array}$} & \multicolumn{3}{|c|}{ Corr. With $y(t+j)$} & \multirow{2}{*}{$\begin{array}{c}\text { Auto } \\
1\end{array}$} \\
\hline & & & & -1 & 0 & 1 & \\
\hline inv. & 2.63 & 1 & -1.57 & 0.10 & -0.02 & -0.01 & 0.04 \\
\hline$y$ & 0.93 & 3 & -0.53 & 0.06 & 0.00 & 0.06 & 0.06 \\
\hline 1 & 1.37 & 2 & -0.31 & -0.09 & -0.30 & -0.31 & -0.02 \\
\hline$w$ & 0.43 & 4 & -0.20 & -0.15 & -0.07 & 0.08 & -0.15 \\
\hline c & 0.42 & 5 & .0 .07 & .0 .17 & .0 .06 & 0.10 & -0.09 \\
\hline
\end{tabular}

(5) $\alpha_{h}=1, \alpha_{y y}=-0.5, \alpha_{\pi}=-0.5, \sigma_{h}=0.75$

\begin{tabular}{|c|c|c|c|c|c|c|c|}
\hline \multirow[t]{2}{*}{ Var. } & \multirow{2}{*}{$\begin{array}{l}\text { SD } \\
\%\end{array}$} & \multirow{2}{*}{$\begin{array}{c}\text { Rank } \\
\text { SD }\end{array}$} & \multirow{2}{*}{$\begin{array}{l}\text { Diff } \\
\text { SD }\end{array}$} & \multicolumn{3}{|c|}{ Corr. With $y(\iota+j)$} & \multirow{2}{*}{$\begin{array}{c}\text { Auto } \\
1\end{array}$} \\
\hline & & & & -1 & 0 & 1 & \\
\hline nv. & 3.26 & $I$ & -0.93 & 0.05 & 0.00 & 0.00 & 0.02 \\
\hline $\bar{y}$ & 1.21 & $2 *$ & -0.24 & 0.02 & 0.00 & 0.00 & 0.02 \\
\hline 1 & 1.21 & 2 & -0.47 & -0.03 & -0.17 & -0.17 & -0.12 \\
\hline$w$ & 0.55 & 4 & .0 .09 & .0 .05 & 0.04 & 0.04 & 0.02 \\
\hline c & 0.47 & 5 & -0.02 & 0.04 & 0.13 & 0.13 & -0.02 \\
\hline
\end{tabular}

(7) CEE Rule

\begin{tabular}{|c|c|c|c|c|c|c|c|}
\hline Var. & SD & Rank & Diff & \multicolumn{2}{|c|}{ Corr. With y(t+j) } & Auto \\
\cline { 5 - 8 } & $\%$ & SD & SD & -1 & 0 & 1 & 1 \\
\hline Inv. & 3.77 & 1 & -0.42 & -0.03 & 0.00 & -0.04 & -0.05 \\
\hline y & 1.37 & $2^{*}$ & -0.08 & -0.03 & 0.00 & -0.03 & -0.03 \\
\hline I & 1.36 & $3^{*}$ & -0.33 & -0.07 & -0.06 & -0.14 & -0.15 \\
\hline w & 0.60 & 4 & -0.04 & -0.03 & -0.02 & 0.05 & 0.02 \\
\hline c & 0.49 & 5 & 0.00 & 0.06 & 0.11 & 0.10 & 0.00 \\
\hline
\end{tabular}

(2) AR-1 Rule( $\left.a_{h}=1, \alpha_{h 1}=0.42, \sigma_{b}=.0075\right)$ compared to the same model under Constant M Growth, without $M$ dist.

\begin{tabular}{|c|c|c|c|c|c|c|c|}
\hline \multirow[t]{2}{*}{ Var. } & \multirow{2}{*}{$\begin{array}{l}\text { SD } \\
\%\end{array}$} & \multirow{2}{*}{$\begin{array}{c}\text { Rank } \\
\text { SD }\end{array}$} & \multirow{2}{*}{$\begin{array}{l}\text { Diff } \\
\text { SD }\end{array}$} & \multicolumn{3}{|c|}{ Corr. With y $(t+j)$} & \multirow{2}{*}{$\begin{array}{c}\text { Auto } \\
1\end{array}$} \\
\hline & & & & -1 & 0 & 1 & \\
\hline inv. & 4.20 & 1 & -0.15 & -0.18 & 0.00 & $=0.10$ & .0 .15 \\
\hline$y$ & 1.45 & 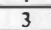 & -0.11 & -0.11 & 0.00 & -0.11 & -0.11 \\
\hline 1 & 1.6 & 2 & 0.11 & -0.06 & 0.33 & 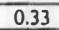 & 0.11 \\
\hline$w$ & 0.64 & 4 & -0.07 & 0.06 & -0.29 & -0.29 & -0.07 \\
\hline c & 0.49 & 5 & 0.02 & -0.08 & .0 .28 & .0 .28 & 0.02 \\
\hline
\end{tabular}

(4) $a_{h}=1, \alpha_{x}=-0.9, \sigma_{h}=0.0075$

\begin{tabular}{|c|c|c|c|c|c|c|c|}
\hline Var. & SD & Rank & Diff & \multicolumn{2}{|c|}{ Corr. With y $(t+j)$} & Auto \\
\cline { 5 - 7 } & $\%$ & SD & SD & -1 & 0 & 1 & 1 \\
\hline inv. & 3.71 & 1 & -0.49 & -0.03 & 0.01 & -0.03 & -0.04 \\
\hline$y$ & 1.41 & $2^{*}$ & -0.05 & -0.04 & 0.00 & -0.04 & -0.04 \\
\hline I & 1.06 & $3^{*}$ & -0.62 & -0.05 & -0.04 & -0.10 & -0.21 \\
\hline$w$ & 0.63 & 4 & -0.01 & -0.01 & 0.06 & 0.09 & 0.09 \\
\hline c & 0.52 & 5 & 0.04 & 0.13 & 0.20 & 0.11 & 0.02 \\
\hline
\end{tabular}

(6) SZ Rule

\begin{tabular}{|c|c|c|c|c|c|c|c|}
\hline Vas. & SD & Rank & Diff & \multicolumn{3}{|c|}{ Corr. With y $(+j)$} & Auto \\
\cline { 5 - 8 } & $\%$ & SD & SD & -1 & 0 & 1 & I \\
\hline inv. & 3.49 & 1 & -0.70 & -0.01 & 0.00 & -0.04 & .0 .04 \\
\hline y & 1.28 & 3 & -0.17 & -0.01 & 0.00 & -0.01 & -0.01 \\
\hline I & 1.31 & 2 & -0.38 & -0.07 & -0.11 & -0.21 & -0.18 \\
\hline w & 0.57 & 4 & -0.07 & -0.06 & -0.02 & 0.09 & 0.00 \\
\hline c & 0.48 & S & -0.01 & 0.04 & 0.11 & 0.14 & -0.01 \\
\hline
\end{tabular}

(8) SZ Rule (79:4-)

\begin{tabular}{|c|c|c|c|c|c|c|c|}
\hline Var. & SD & Rank & Diff & \multicolumn{3}{|c|}{ Corr. With y(t+j) } & Auto \\
\cline { 5 - 7 } & $\%$ & SD & SD & -1 & 0 & 1 & 1 \\
\hline inv. & 3.41 & 1 & -0.79 & -0.06 & 0.00 & -0.09 & -0.09 \\
\hline$y$ & 1.24 & 3 & -0.21 & -0.06 & 0.00 & -0.06 & -0.21 \\
\hline I & 1.33 & 2 & -0.35 & -0.15 & -0.14 & -0.23 & -0.35 \\
\hline w & 0.55 & 4 & -0.09 & -0.07 & -0.10 & 0.01 & -0.09 \\
\hline$c$ & 0.47 & 5 & -0.02 & 0.00 & 0.08 & 0.08 & -0.02 \\
\hline
\end{tabular}


Table I2. Nominal Features of Business Cycles (with Monetary Disturbances)

a) U.S. Data

\begin{tabular}{|c|c|c|c|c|c|c|c|}
\hline \multirow[t]{2}{*}{ Period } & \multirow[t]{2}{*}{ Variables } & \multicolumn{3}{|c|}{ Standard Deviation \% } & \multicolumn{3}{|c|}{ Correfation with Output } \\
\hline & & inflation & nom. int & Mgr & Inflation & Nom. int. & $\mathrm{Mgr}$ \\
\hline \multirow[t]{3}{*}{$60-96$} & GNPD, TBR, MI & 0.30 & 1.29 & 0.83 & 0.15 & 0.34 & -0.15 \\
\hline & $\mathrm{CPl}, \quad \mathrm{M} 2$ & 0.46 & & 0.64 & 0.40 & & 0.01 \\
\hline & MB & & & 0.45 & & & -0.28 \\
\hline \multirow[t]{3}{*}{ 79:4-96 } & GNPD, TBR, Ml & 0.24 & 1.50 & 1.10 & 0.24 & 0.26 & -0.25 \\
\hline & CPI, & 0.47 & & 0.62 & 0.32 & & -0.14 \\
\hline & $\mathrm{CPI}$ & & & 0.54 & & . & -0.17 \\
\hline
\end{tabular}

b) Models

\begin{tabular}{|c|c|c|c|c|c|c|c|}
\hline \multirow[t]{2}{*}{ Model } & \multirow[t]{2}{*}{ Policy Rule } & \multicolumn{3}{|c|}{ Standard Deviation \% } & \multicolumn{3}{|c|}{ Correlation witb Output } \\
\hline & & inflation & nom. int & Mgr & Inflation & Nom. int. & $\mathrm{Mgr}$ \\
\hline \multirow[t]{7}{*}{ RBC } & AR-1 & 1.31 & 0.31 & 0.77 & -0.30 & 0.29 & 0.00 \\
\hline & Counter-cyclical & 2.22 & 0.13 & 1.29 & -0.35 & 1.00 & -0.31 \\
\hline & counter-inflation & 0.67 & 0.07 & 0.63 & -0.31 & 0.98 & 0.30 \\
\hline & counter-cyc \& inf & 1.16 & 0.09 & 0.49 & -0.34 & 0.99 & 0.00 \\
\hline & SZ & 1.23 & 0.10 & 0.65 & -0.36 & 0.32 & -0.08 \\
\hline & CEE & 1.04 & 0.09 & 0.64 & -0.31 & 0.88 & 0.12 \\
\hline & SZ(79:4-) & 1.30 & 0.36 & 0.38 & -0.42 & -0.28 & -0.17 \\
\hline \multirow[t]{7}{*}{ NWC-1 } & AR-I & 1.06 & 0.75 & 0.77 & -0.13 & 0.35 & 0.35 \\
\hline & Counter-cyclical & 1.49 & 1.19 & 0.88 & -0.20 & 0.23 & -0.12 \\
\hline & counter-inflation & 0.57 & 0.16 & 0.72 & -0.21 & 0.52 & 0.38 \\
\hline & counter-cyc \& inf & 0.82 & 0.04 & 0.48 & -0.20 & 0.22 & 0.21 \\
\hline & $\mathrm{SZ}$ & 0.74 & 0.04 & 0.85 & -0.10 & 0.25 & 0.30 \\
\hline & CEE & 0.77 & 0.36 & 0.71 & -0.13 & 0.35 & 0.35 \\
\hline & S2 $(79: 4-)$ & 0.61 & 0.05 & 0.71 & -0.26 & 0.00 & 0.27 \\
\hline \multirow[t]{7}{*}{$\mathrm{NWC}-\bar{M}$} & AR-1 & 0.98 & 0.52 & 0.77 & -0.07 & 0.35 & 0.31 \\
\hline & Counter-cyclical & 1.16 & 0.54 & 0.74 & .0 .16 & 0.05 & -0.04 \\
\hline & counter-inflation & 0.58 & 0.14 & 0.69 & -0.26 & 0.60 & 0.38 \\
\hline & counter-cyc \& inf & 0.82 & 0.22 & 0.48 & -0.24 & 0.25 & 0.18 \\
\hline & SZ & 0.84 & 0.22 & 0.66 & -0.19 & 0.22 & 0.22 \\
\hline & CEE & 0.78 & 0.22 & 0.69 & -0.17 & 0.41 & 0.31 \\
\hline & SZ(79:4-) & 0.88 & 0.35 & 0.79 & -0.20 & 0.01 & 0.18 \\
\hline \multirow[t]{7}{*}{ MC-0 } & AR:1 & 1.31 & 0.31 & 0.77 & -0.31 & 0.28 & 0.00 \\
\hline & Counter-cyclical & 2.38 & 0.13 & 1.36 & -0.36 & 1.00 & -0.32 \\
\hline & counter-inflation & 0.71 & 0.07 & 0.66 & -0.32 & 0.98 & 0.30 \\
\hline & counter-cyc \& inf & 1.23 & 0.09 & 0.49 & .0 .34 & 0.99 & 0.00 \\
\hline & $\mathrm{SZ}$ & 1.30 & 0.11 & 0.65 & -0.37 & 0.27 & -0.08 \\
\hline & CEE & 1.09 & 0.09 & 0.64 & -0.31 & 0.87 & 0.13 \\
\hline & $\mathrm{SZ}(79: 4-)$ & 1.37 & 0.38 & 0.87 & .0 .43 & .0 .30 & -0.18 \\
\hline \multirow[t]{7}{*}{ MC-1 } & AR-1 & 1.14 & 0.41 & 0.77 & -0.18 & 0.20 & 0.14 \\
\hline & Counter-cyclical & 1.65 & 0.48 & 0.98 & -0.23 & -0.04 & -0.17 \\
\hline & counter-inflation & 0.64 & 0.07 & 0.64 & -0.26 & 0.70 & 0.29 \\
\hline & counter-cyc \& inf & 1.02 & 0.16 & 0.49 & -0.27 & 0.20 & 0.06 \\
\hline & SZ & 1.08 & 0.21 & 0.65 & -0.26 & 0.03 & 0.04 \\
\hline & CEE & 0.94 & 0.15 & 0.66 & -0.23 & 0.31 & 0.17 \\
\hline & SZ(79:4-) & 1.10 & 0.42 & 0.81 & -0.30 & -0.20 & -0.04 \\
\hline \multirow[t]{2}{*}{ MC.5 } & AR-1 & 0.65 & 0.50 & 0.77 & 0.21 & 0.43 & 0.44 \\
\hline & Counter-cyclical & 0.66 & 0.50 & 0.53 & -0.02 & 0.06 & 0.14 \\
\hline
\end{tabular}




\begin{tabular}{|l|l|r|r|r|r|r|r|}
\hline & counter-inflation & 0.44 & 0.02 & 0.64 & -0.08 & 0.23 & 0.30 \\
\hline & counter-cyc \& inf & 0.55 & 0.31 & 0.48 & -0.07 & 0.08 & 0.22 \\
\hline & SZ & 0.58 & 0.32 & 0.65 & 0.01 & 0.17 & 0.30 \\
\hline & CEE & 0.55 & 0.30 & 0.70 & 0.03 & 0.24 & 0.33 \\
\hline & SZ(79:4-) & 0.59 & 0.38 & 0.77 & 0.02 & 0.11 & 0.29 \\
\hline MC-15 & AR-1 & 0.30 & 0.35 & 0.77 & 0.51 & 0.68 & 0.46 \\
\hline & Counter-cyclical & 0.25 & 0.26 & 0.40 & 0.15 & 0.23 & 0.37 \\
\hline & counter-inflation & 0.23 & 0.19 & 0.68 & 0.17 & 0.38 & 0.36 \\
\hline & counter-cyc \& inf & 0.25 & 0.23 & 0.49 & 0.13 & 0.26 & 0.35 \\
\hline & SZ & 0.26 & 0.24 & 0.65 & 0.26 & 0.41 & 0.41 \\
\hline & CEE & 0.26 & 0.25 & 0.73 & 0.31 & 0.48 & 0.42 \\
\hline & SZ(79:4-) & 0.26 & 0.25 & 0.78 & 0.31 & 0.42 & 0.44 \\
\hline NWC-1 & AR-1 & 0.63 & 0.60 & 0.77 & 0.25 & 0.56 & 0.56 \\
\hline MC-5 & Counter-cyclical & 0.59 & 0.56 & 0.46 & -0.01 & 0.20 & 0.21 \\
\hline & counter-inflation & 0.40 & 0.24 & 0.76 & -0.06 & 0.39 & 0.39 \\
\hline & counter-cyc \& inf & 0.49 & 0.40 & 0.53 & -0.02 & 0.27 & 0.35 \\
\hline & SZ & 0.49 & 0.39 & 0.66 & 0.02 & 0.34 & 0.41 \\
\hline & CEE & 0.50 & 0.40 & 0.75 & 0.06 & 0.42 & 0.45 \\
\hline & SZ(79:4-) & 0.50 & 0.42 & 0.77 & -0.01 & 0.26 & 0.39 \\
\hline
\end{tabular}


Figure 1. impulse response to monetary policy shocks - RBC Model
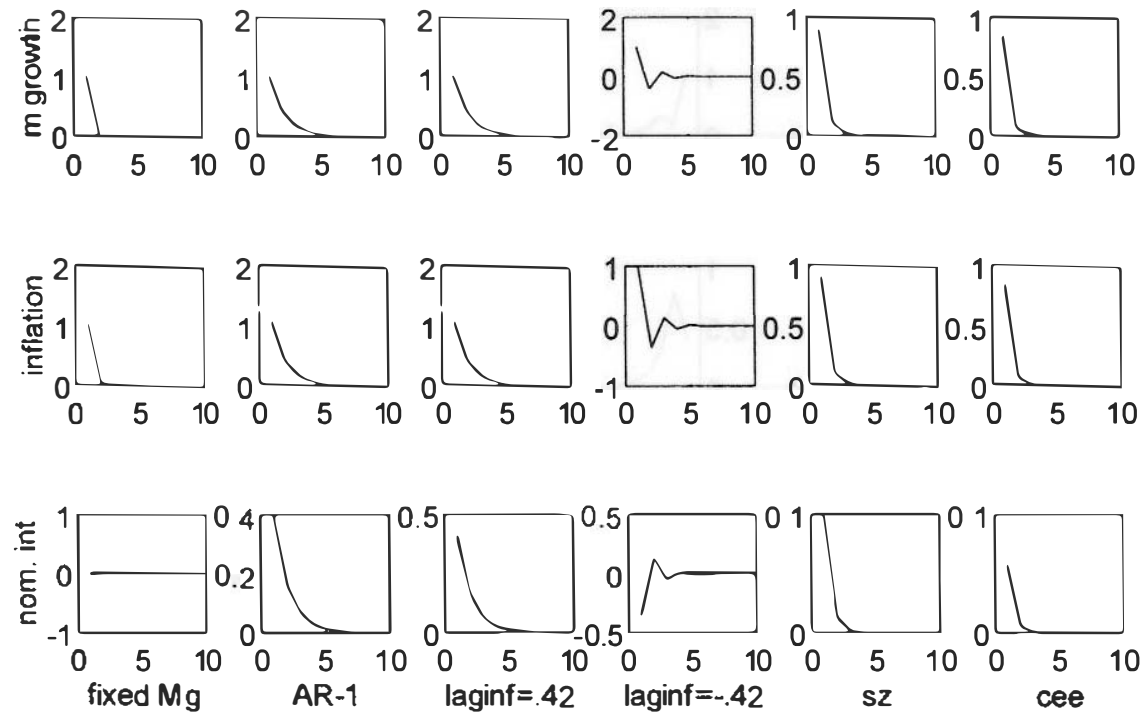
Figure 2. Impulse Responses to Monetary Policy Shocks - NWC-1 Model
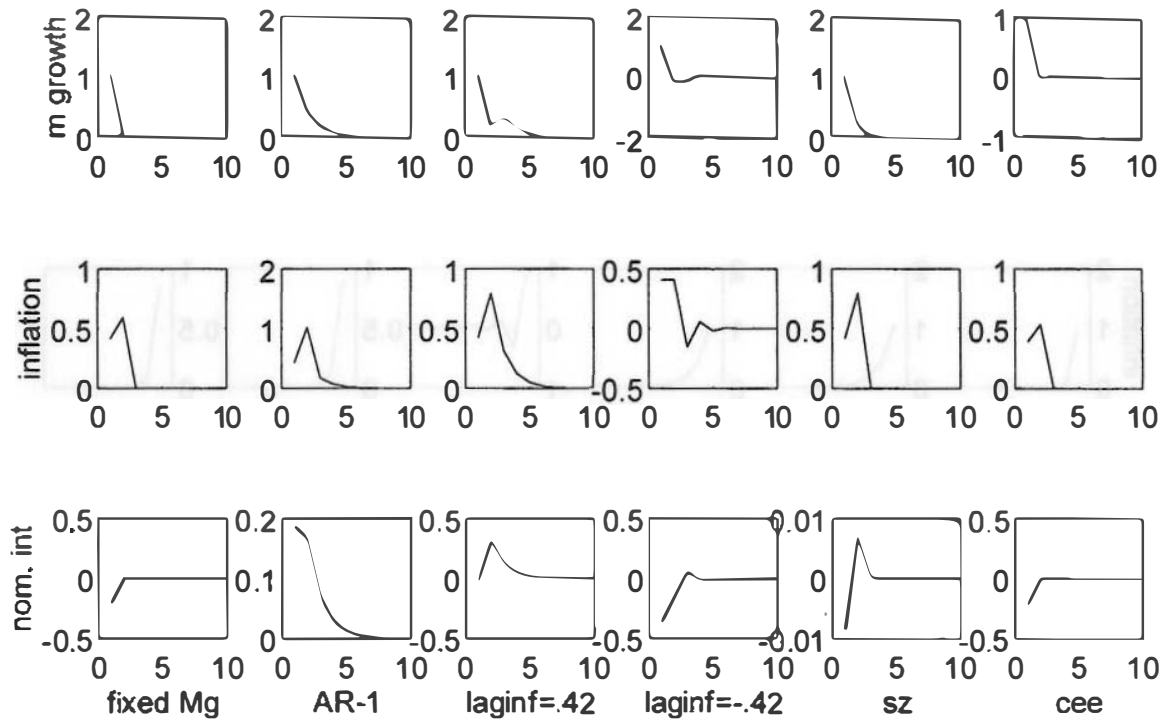
Figure 3. Impulse Responses to M Shocks
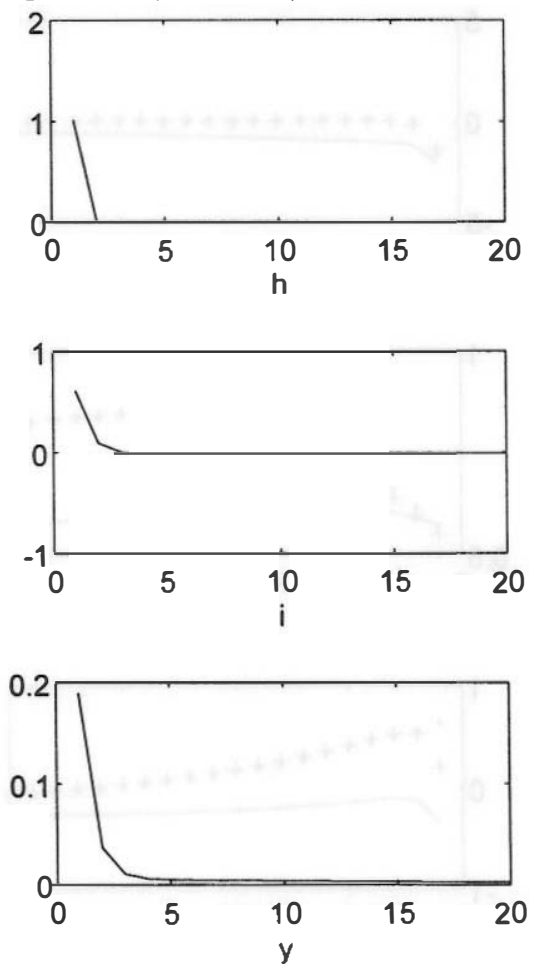

$-M C-1$
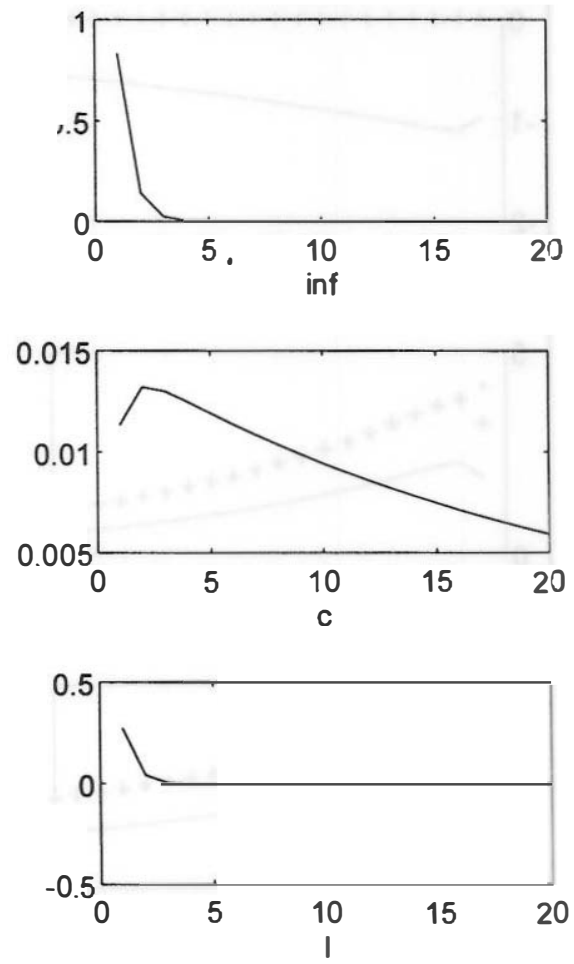
Figure 4. Impulse Responses to Prod Shocks
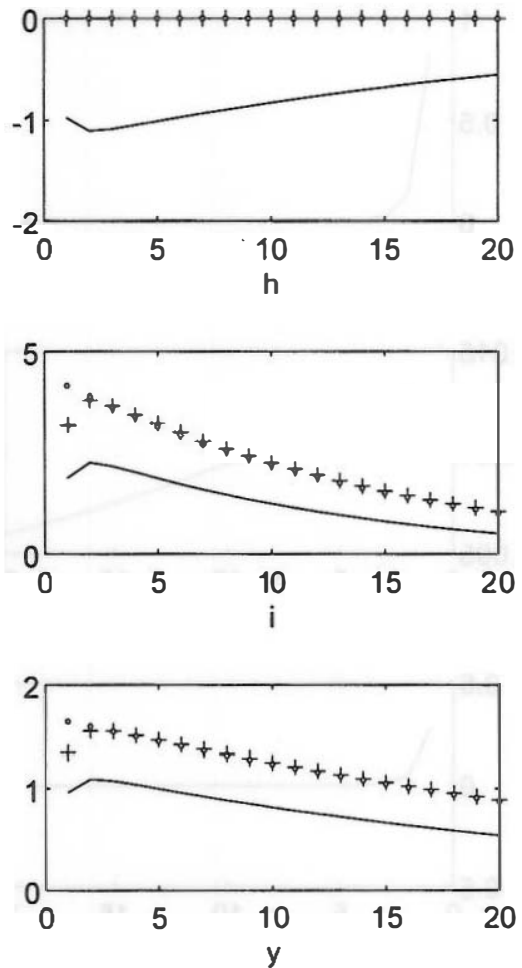

$-M C-1$
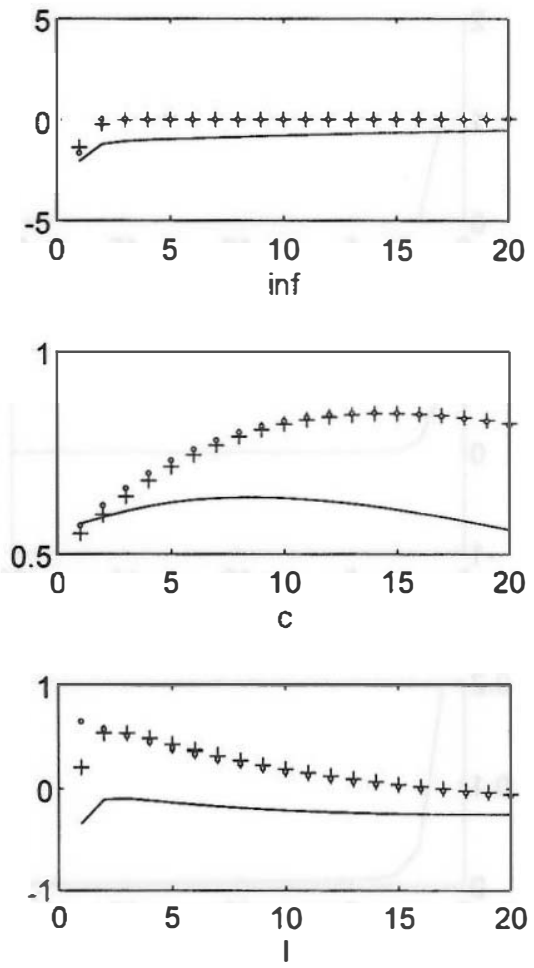

Dotted line: MC-1 under the constant money growth rate rule

Solid line: MC-I under the feodback rule on the level of output

"+" line: MC-0 under the constant money growth rate rule 


\section{References}

Aiyagari, S. Rao and R. Anton Braun, 1996, Some Explorations into Optimal Cyclical Monetıry Policy, Working Paper 565, Research Department, Federal Reserve Bank of Minneapolis.

Bergin, Paul, 1996, Mundell-Flemming Deconstructed: Reconsidering Policy and Spillovers With and Without Wage Contracts, mimeo, Yale University.

Blanchard, Oliver J., and Nobuhiro Kiyotaki, 1987, Monopolistic Competition and the Effecı of Aggregate Demand, American Economic Review 77, 647-666.

Bryant, Ralph C., Peter Hooper, and Catherine L. Mann, 1993, eds. Evaluating Policy Regimes: N'ew Research in Empirical Macroeconomics, Washington D.C.: Brookings, 1993.

Chari, V.V., Lawrence Christiano, and Martin Eichenbaum, 1995, Policy Analysis in Business Cycle Models, in Frontiers of Business Cycle Research, Thomas F. Cooley (ed.), Princeton University Press, Princeton, NJ.

Cho, Jang-Ok and Thomas Cooley, 1995, The Business Cycle with Nominal Contracts, Economic Theory, Vol. 6, No 1, 13-33.

Cho, Jang-Ok and Louis Phaneuf, "A Business cycle Model with Nominal Contracts and Government," Institute for Empirical macroeconomics, Federal Reserve Bank of Minneapolis Discussion Paper 80, Feb. 1993.

Christiano, Lawrence, Martin Eichenbaum, and Charles Evans, 1992, Liquidity Effects and the Monetary Transmission Mechanism, American Economic Review, Vol. 82, No. 2, 346-353.

Christiano, Lawrence, Martin Eichenbaum, and Charles Evans, 1995, Liquidity Effects, Monetary Policy and the Business Cycle, Journal of Money, Credit, and Banking, November, Part 1, 1113-6.

Christiano, Lawrence, Martin Eichenbaum, and Charles Evans, 1996, The Effects of monetary Policy Shocks: Evidence From the Flow of Funds, Review of Economics and Statistics February Vol. LXXVIII, 16-34.

Christiano, Lawrence, Martin Eichenbaum, and Charles Evans, 1997a, Sticky Price and Limited Participation Models of Money: A Comparison, European Economic Review 41, 1201-1249.

Christiano, Lawrence, Martin Eichenbaum, and Charles Evans, 1997b, Modeling Money, presented at the CEPR meeting in January 1997.

Carlstrom, Charles T. and Timothy S. Fuerst, 1995, Interest Rate Rules vs. Money Growth Rules, A Welfare Comparison in a Cash-in-Advance Economy, Journal of Monetary Economics 36, 247-267. 
Croley, Thomas F. and Gayy D. Hansen, 1989, The Inflation Tax in a Real Business Cycle Model, American Economic Review 79, 733-48.

Cooley, Thomas F. and Gary D. Hansen, 1995, Money and Business Cycle, in Frontiers of Business Cycle Research, Thomas F. Cooley (ed.), Princeton University Press, Princeton, NJ.

Ccoley, Thomas F. and Edward C. Prescott, 1995, Economic Growth and Business Cycles, in Frontiers of Business Cycle Research, Thomas F. Cooley (ed.), Princeton University Press, Princeton, NJ.

Fuerst, Timothy S., 1992, liquidity, Loanable Funds, and Real Activity, Journal of Monetary Economics 29, 3-24.

Fuhrer, Jeffrey C. and George R. Moore, 1995, Monetary Policy Trade-offs and the Correlation between Nominal Interest Rates and Real Output, American Economic Review, Vol. 85, No.1, inarch.

Gavin, William T. and Finn E. Kydland, 1996, Endogenous Money Supply and The Business Cycle, Research Division Working Papers, 95-010C, Federal Reserve Bank of St. Louis

Hairault, Jean-Oliver and Franck Portier, 1993, Money, New-Keynesian Macroeconomics and the Business Cycle, European Economic Review 37, 1533-1568.

Kim, Jinill, 1996, Monetary Policy in a Stochastic Equilibrium Model with Real and Nominal Rigidities, mimeo, Yale University.

Kinn, Soyoung, 1995, Does Monetary Policy Matter in the G-6 Countries? Using Common IJentifying Assumptions about Monetary Policy Across Countries, mimeo, Yale University.

Kinn, Soyoung, 1996, Monetary Instrument Problem Revisited by Specifying Appropriate Fiscal F'olicies, mimeo, Yale University.

King, G. Robert, 1992, Money and Business Cycles, mimeo, University of Rochester.

King, G. Robert, Charles I. Plosser and Sergio T. Rebelo, 1988, Production, Growth and Fusiness Cycles: 1. The Basic Neoclassical Model, Journal of Monetary Economics 21, 195232.

King, G. Robert and Mark W. Watson, 1996, Money, Prices, Interest Rates and the Business Cycle, Review of Economics and Statistics, February, Vol. LXXVIII, 35-54.

Lecper, Eric M., 1991, Equilibria under "Active" and "Passive" Monetary and Fiscal Policies, Journal of Monetary Economics 27, 129-147.

Leeper, Eric M., 1993, The Policy Tango: Toward a Holistic View of Monetary and Fiscal Effects, Economic Review, Federal Reserve Bank of Atlanta, July/August, 1-27. 
Leeper, Eric M. and Christopher A. Sims, 1994, Toward a Modern Macroeconomic Model Usable for Policy Analysis, NBER Macroeconomics Annual.

Leeper, Eric M., Christopher A. Sims, and Tao Zha, 1996, What Does Monetary Policy Do? Brookings Papers on Economic Activity, 1-63.

Lucas, Robert E., Jr., 1990, Liquidity and Interest Rates, Journal of Economic Theory 50, 237. 264.

Poole, William, 1970, Optimal Choice of Monetary Policy Instrument in a Simple Stochastic Macro Model, Quarterly Journal of Economics 84, 197-216.

Rotemberg, Julio J. and Michael Woodford, 1995, Dynamic General Equilibrium Mode's with Imperfectly Competitive Product Markets, in Frontiers of Business Cycle Research, Thomas F. Cooley (ed.), Princeton University Press, Princeton, NJ.

Rotemberg, Julio J. and Michael Woodford, 1997, An Optimization-Based Econometric Framework for the Evaluation of Monetary Policy, mimeo, Princeton University

Sargent, T.J. and N. Wallace, 1975, "Rational" Expectations, the Optimal Monetary Instrument, and the Optimal Money Supply Rule, Journal of Political Economy 83, 241-254.

Sargent, T.J. and N. Wallace, 1982, The Real-Bills Doctrine versus the Quantity Theory: A Reconsideration, Journal of Political Economy 90, 1212-1236.

Sims, C.A., 1995, Solving Linear Rational Expectation Models, manuscript, Yale University.

Sims, Christopher A. and Tao Zha, 1995, Does Monetary Policy Generate Recessions?: Using Less Aggregate Price Data to Identify Monetary Policy, mimeo, Yale University.

Stock, J. and Mark Watson, 1993, A Simple Estimator of Cointegrating Vectors in Higher Order Cointegrated Systems, Econometrica 61, 783-820/

Taylor, John B., 1993, Macroeconomic Policy in a World Economy: From Econometric Design to Practical Operation, W. W. Norton \& Company: New York, London.

Yun, Tack, Nominal Price Rigidity, Money Supply Endogeneity, and Business Cycles, Journal of Monetary Economics 1996. 



\section{WORKING PAPERS (1)}

9525 Aurora Alejano y Juan M." Peñalosa: La integración financiera de la economía española: efectos sobre los mercados financieros y la política monetaria.

9526 Ramón Gómez Salvador y Juan J. Dolado: Creación y destrucción de empleo en España: un análisis descriptivo con datos de la CBBE.

9527 Santiago Femández de Lis y Javier Santillán: Regímenes cambiarios e integración monetaria en Europa.

9528 Gabriel Quirós: Mercados financieros alemanes.

9529 Juan Ayuso Huertas: Is there a trade-off between exchange rate risk and interest rate risk? (The Spanish original of this publication has the same number.)

9530 Fernando Restoy: Determinantes de la curva de rendimientos: hipótesis expectacional y primas de riesgo.

9531 Juan Ayuso and María Pérez Jurado: Devaluations and depreciation expectations in the EMS.

9532 Paul Schulstad and Ángel Serrat: An Empirical Examination of a Multilateral Target Zone Model.

9601 Juan Ayuso, Soledad Núñez and María Pérez-Jurado: Volatility in Spanish financial market: The recent experience.

9602 Javier Andrés e Ignacio Hernando: ¿Cómo afecta la inflación al crecimiento económico? Evidencia para los países de la OCDE.

9603 Barbara Dluhosch: On the fate of newcomers in the European Union: Lessons from the Spanish experience.

9604 Santiago Fernández de Lis: Classifications of Central Banks by Autonomy: A comparative analysis.

9605 M.* Cruz Manzano Frías y Sofia Galmés Belmonte: Credit Institutions' Price Policies and Type of Customer: Impact on the Monetary Transmission Mechanism. (The Spanish original of this publication has the same number.)

9606 Malte Krïger: Speculation, Hedging and Intermediation in the Foreign Exchange Market.

9607 Agustín Maravall: Short-Term Analysis of Macroeconomic Time Series.

9608 Agustin Maravall and Christophe Planas: Estimation Error and the Specification of Unobserved Component Models.

9609 Agustín Maravall: Unobserved Components in Economic Time Series.

9610 Matthew B. Canzoneri, Behzad Diba and Gwen Eudey: Trends in European Productivicy and Real Exchange Rates.

9611 Francisco Alonso, Jorge Martínez Pagés y María Pérez Jurado: Weighted Monetary Aggregates: an Empirical Approach. (The Spanish original of this publication has the sanıe number.)

9612 Agustin Maravall and Daniel Peña: Missing Observations and Additive Outliers in Tinıe Series Models.

9613 Juan Ayuso and Juan L. Vega: An empirical analysis of the peseta's exchange rate dynamics.

9614 Juan Ayuso Huertas. Un análisis empírico de los tipos de interés reales ex-ante en España.

9615 Enrique Alberola Da: Optimal exchange rate targets and macroeconomic stabilization. 
9616 A. Jorge Padilla, Samuel Bentolila and Juan J. Dolado: Wage bargaining in industries with market power.

9617 Juan J. Dolado and Francesc Marnol: Efficient estimation of cointegrating relationships among higher order and fractionally integrated processes.

9618 Juan J. Dolado y Ramón Gómez: La relación entre vacantes y desempleo en España: perturbaciones agregadas y de reasignación.

9í19 Alberto Cabrero and Juan Carlos Delrieu: Construction of a composite indicator for predicting inflation in Spain. (The Spanish original of this publication has the same number.)

9i20 Una-Louise Bell: Adjustment costs, uncertainty and employment inertia.

gri21 M.* de los Llanos Matea y Ana Valentina Regil: Indicadores de inflación a corto plazo.

9ri22 James Conklin: Computing value correspondences for repeated games with state variables.

9ri23 James Conklin: The theory of sovereign debt and Spain under Philip II.

9624 José Viñals and Juan F. Jimeno: Monetary Union and European unemployment.

9i25 Marí Jesús Nieto Carol: Central and Eastem European Financial Systems: Towards integration in the European Union.

9i26 Matthew B. Canzoneri, Javier Vallés and José Viñals: Do exchange rates move to address international macroeconomic imbalances?

96.27 Enrique Alberola Ila: Integración económica y unión monetaria: el contraste entre Norteamérica y Europa.

9 28 Víctor Gómez and Agustín Maravall: Programs TRAMO and SEATS.

צt29 Javier Andrés, Ricando Mestre y Javier Vallés: Un modelo estructural para el análisis del mecanismo de transmisión monetaria: el caso español.

9 ×30 Francisco Alonso y Juan Ayuso: Una estimación de las primas de riesgo por inflación en el caso español.

9631 Javier Santillán: Política cambiaria y autonomía del Banco Central.

9632 Marcial Suárez: Vocábula (Notas sobre usos lingüísticos).

9633 Juan Ayuso and J. David López-Salido: What does consumption tell us about inflation expectations and real interest rates?

9701 Victor Gómez, Agustin Maravall and Daniel Peña: Missing observations in ARIMA models: Skipping strategy versus outlier approach.

9702 José Ranón Martínez Resano: Los contratos DIFF y el tipo de cambio.

9703 Gabriel Quirós Romero: Una valoración comparativa del mercado espan̄ol de deuda pública.

$97: 94$ Agustín Maravall: Two discussions on new seasonal adjustment methods.

9705 J. David López-Salido y Pilar Velilla: La dinámica de los márgenes en España (Una primera aproximación con datos agregados).

97\%6 Javier Andrés and Ignacio Hemando: Does inflation harm economic growth? Evidence for the OECD. 
9707 Marga Peeters: Does demand and price uncertainty affect Belgian and Spanish corporate investment?

9708 Jeff rey Franks: Labor market policies and unemployment dynamics in Spain.

9709 José Ramón Martínez Resano: Los mercados de derivados y el euro.

9710 Juan Ayuso and J. David López-Salido: Are ex-post real interest rates a good proxy fcr ex-ante real rates? An international comparison within a CCAPM framework.

9711 Ana Buisán y Miguel Pérez: Un indicador de gasto en construcción para la economía españolí.

9712 Juan J. Dolado, J. David López-Salido and Juan Luis Vega: Spanish unemployment and iıflation persistence: Are there phillips trade- of fs?

9713 José M. González Mínguez: The balance-sheet transmission channel of monetary policy: The cases of Germany and Spain.

9714 Olympia Bover: Cambios en la composición del empleo y actividad laboral femenina.

9715 Francisco de Castro and Alfonso Novales: The joint dynamics of spot and forward exchange rates.

9716 Juan Carios Caballero, Jorge Martínez y M." Teresa Sastre: La utilización de los índices c!e condiciones monetarias desde la perspectiva de un banco central.

9717 José Viñals y Juan E Jimeno: EI mercado de trabajo español y la Unión Económica y Mi)netaria Europea.

9718 Samuel Bentolila: La inmovilidad del trabajo en las regiones españolas.

9719 Enrique Alberola, Juan Ayuso and J. David López-Salido: When may peseta depreciations fuel inflation?

9720 José M. González Mínguez: The back calculation of nominal historical series after the intri)duction of the european currency (An application to the GDP).

9721 Una-Louise Bell: A Comparative Analysis of the Aggregate Matching Process in France, Great Britain and Spain.

9722 Francisco Alonso Sánchez, Juan Ayuso Huertas y Jorge Martínez Pagés: El poder predictivo de los tipos de interés sobre la tasa de inflación española.

9723 Isabel Argimón, Concha Artola y José Manuel González-Páramo: Empresa pública y ernpresa privada: titularidad y eficiencia relativa.

9724 Enrique Alberola and Pierfederico Asdrubali: How do countries smooth regional disturbances? Risksharing in Spain: 1973-1993.

9725 Enrique Alberola, José Manuel Marqués and Alicia Sanchís: Unemployment persistence, Central Bank independence and inflation performance in the OECD countries. (The Spanish original of this publication has the same number.)

9726 Francisco Alonso, Juan Ayuso and Jorge Martínez Pagés: How informative are financial asset prices in Spain?

9727 Javier Andrés, Ricardo Mestre and Javier Vallés: Monetary policy and exchange rate dynamics in the Spanish economy.

9728 Juan J. Dolado, José M. González-Páramo y José Viñals: A cost- benefit analysis of going from low inflation to price stability in Spain. 
\$801 Ángel Estrada, Pilar García Perea, Alberto Urtasun y Jesús Briones: Indicadores de precios, costes y márgenes en las diversas ramas productivas.

S802 Pilar Álvarez Canal: Evolución de la banca extranjera en el período 1992-1996.

S803 Ángel Estrada y Alberto Urtasun: Cuantificación de expectativas a partir de las encuestas de opinión.

9804 Soyoung Kim: Monetary Policy Rules and Business Cycles.

(1) Previously published Working Papers are listed in the Banco de España publications catalogue.

Queries should be addressed to: Banco de España

Sección de Publicaciones. Negociado de Distribución y Gestión

Telephone: 3385180

Alcalá, 50. 28014 Madrid 